\title{
THE RESURFICE EXCEPTION
}

\section{Causation in Negligence Without Probability}

\author{
by
}

\section{David Cheifetz}

A thesis submitted in conformity with the requirements

for the degree of Masters of Laws

Graduate Department of the Faculty of Law

University of Toronto

(C) Copyright by David Cheifetz (2012) 


\title{
THE RESURFICE EXCEPTION
}

\section{Causation in Negligence Without Probability}

\author{
David Cheifetz \\ Master of Laws
}

Faculty of Law

University of Toronto

2012

\begin{abstract}
Resurfice Corp. v. Hanke, [2007] 1 S.C.R. 333, 2007 SCC 7, creates a new causation doctrine in Canadian negligence law that is available to plaintiffs only in exceptional cases. Under this doctrine, negligence and the possibility of specific factual causation may be sufficient to satisfy the causation requirements of a cause of action in negligence. Proof of specific factual causation on the balance of probability is not required. The justification for this doctrine is fairness and justice. The application of the doctrine does not produce a decision that the negligence did cause the injury. Where the requirements of the Resurfice doctrine are satisfied, the causation requirements of the cause of action are deemed to be satisfied despite the finding that factual causation was not established on the balance of probability. The authorities cited are current to June 21, 2012.
\end{abstract}




\section{Acknowledgments}

I am indebted to Vaughan Black, Russ Brown, Lewis Klar, Erik Knutsen, Angela Swan, Ernie Weinrib, and Richard Wright, for their advice and comments at various times over the past

few years. I am also indebted to them for their encouragement. I am also grateful for the comments on causation issues by various members of the Obligations Discussion Group. 


\section{Preface}

This thesis was submitted and approved before the release of Clements v. Clements, 2012 SCC 32, on June 29, 2012. The Supreme Court restated aspects of the material contribution doctrine set out in Resurfice Corp. v. Hanke, [2007] 1 S.C.R. 333, 2007 SCC 7. The content has not been revised to take into account the discussion in Clements. Statements in Clements render aspects of my analysis of the doctrine necessarily wrong. Other statements, and implications of those statements, may make the central premise of the thesis - that the application of material contribution to risk does not produce a finding of factual causation on the balance of probability - wrong.

August 5, 2012 


\section{Table of Contents}

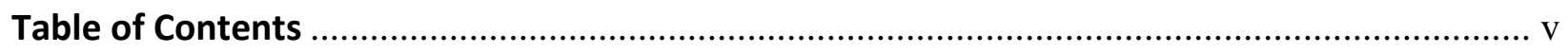

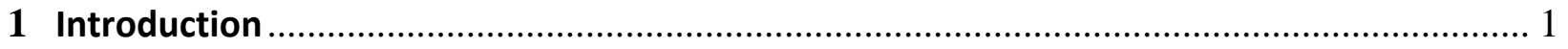

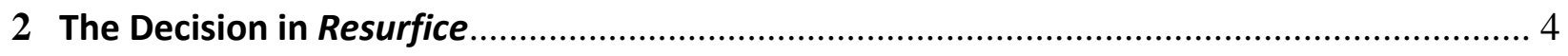

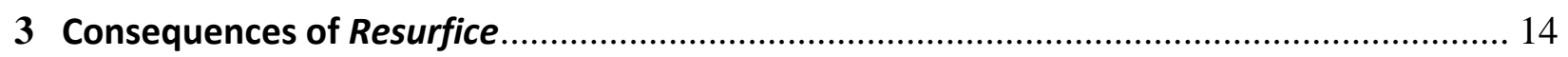

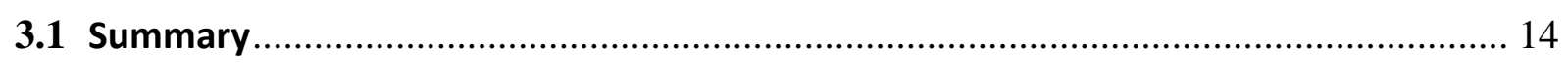

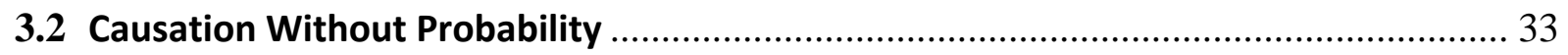

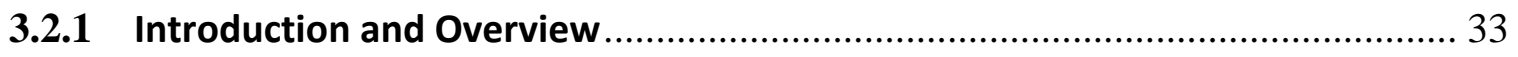

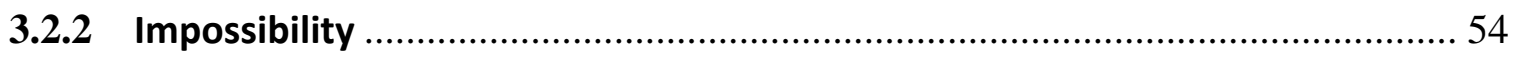

3.2.2.1 Logical Impossibility and Insufficient Evidence ............................... 54

3.2.2.2 Decision Causation or Dependency Causation .................................. 79

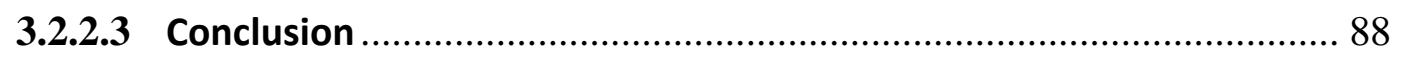

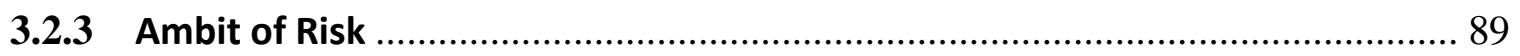

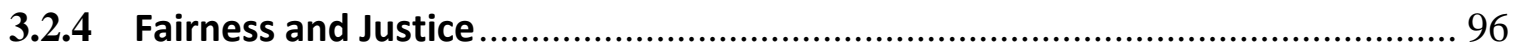

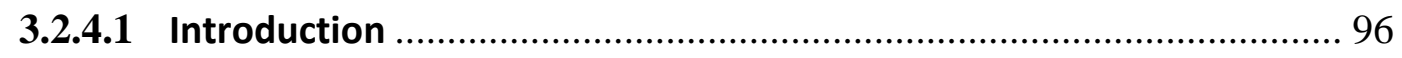

3.2.4.2 "Fairness and Justice" is a Third Requirement ................................. 99

3.2.4.3 Factors that Might Satisfy the Fairness and Justice Requirement..... 105

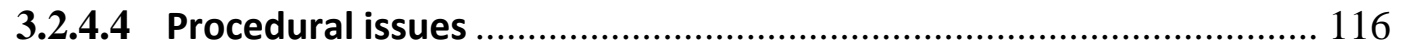

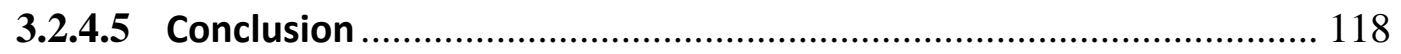

3.2.5 "Material" Increase in Risk - How Much Possibility is Enough Possibility? .... 120

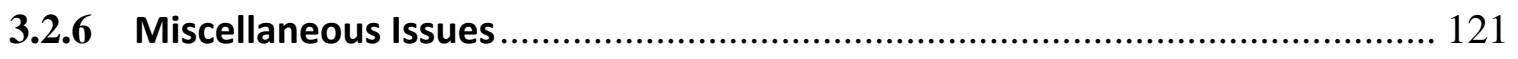

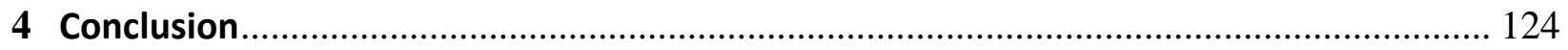




\section{Introduction}

In Resurfice Corp. v. Hanke, ${ }^{1}$ the Supreme Court of Canada set out a new test for proof of causation in negligence called a "material contribution" test. Under the Resurfice version of material contribution, a plaintiff may be able to satisfy the specific causation requirements of a cause of action in negligence, notwithstanding the plaintiff failed to establish factual causation on the balance of probability. ${ }^{2}$

... [I]n special circumstances, the law has recognized exceptions to the basic "but for" test, and applied a "material contribution" test. Broadly speaking, the cases in which the "material contribution" test is properly applied involve two requirements.

First, it must be impossible for the plaintiff to prove that the defendant's negligence caused the plaintiff's injury using the "but for" test. The impossibility must be due to factors that are outside of the plaintiff's control; for example, current limits of scientific knowledge. Second, it must be clear that the defendant breached a duty of care owed to the plaintiff, thereby exposing the plaintiff to an unreasonable risk of injury, and the plaintiff must have suffered that form of injury. In other words, the plaintiff's injury must fall within the ambit of the risk created by the defendant's breach. In those exceptional cases where these two requirements are satisfied, liability may be imposed, even though the "but for" test is not satisfied, because it would offend basic notions of fairness and justice to deny liability by applying a "but for" approach. $^{3}$

Resurfice material contribution is not based on fault and proof of specific factual causation on the balance of probability. It is based on fault and proof of a possibility less than a probability of specific factual causation. ${ }^{4}$

1 [2007] 1 S.C.R. 333, 2007 SCC 7, rev'g 2005 ABCA 383, rev'g 2003 ABQB 616 [Resurfice, cited to S.C.R. unless otherwise indicated]. All references to a material contribution test are references to the Resurfice version unless otherwise stated.

2

2 Resurfice, supra note 1 at paras. 24-29. See Chapter 3.2.

3 Ibid., paras. 24-25.

4

"Factual causation" means specific factual causation unless otherwise indicated. Specific factual causation answers the question: Did the negligence cause the injury? - meaning: was the negligence a factual cause of the injury sustained by a plaintiff? General causation answers the question: can the negligence be a cause the injury? meaning: is the negligence capable of causing the injury? See, inter alia, Harrington v. Dow Corning Corp, 2000 BCCA 605 at paras. 42, 46, 193 D.L.R. (4th) 67. General causation is usually not an issue in traumatic injury cases or in property damage cases. A collision between a human body and a hard, massive enough, object moving at sufficient speed is capable of causing some injury to the person. A large enough, hot enough, fire is capable of causing some damage to a building or other property. A massive enough vehicle is capable of causing some 
This paper is an analysis of the Resurfice material contribution doctrine. Since that doctrine is based on the existence of factual causation, it cannot be usefully discussed without an explanation of factual causation in law. Accordingly, the doctrine cannot be usefully discussed without some reference to the but-for test and what Resurfice says, or seems to say, about the meaning of but-for doctrine. However, as the focus of this paper is Resurfice material contribution, the discussion of the meaning of factual causation, and but-for doctrine, is limited to what is needed for the discussion of Resurfice material contribution. ${ }^{5}$ In this paper, factual causation is the subject of the inquiry into how injury occurred in a physical sense. ${ }^{6}$ In law, the factual causation inquiry asks two questions: (1) Is the wrongful conduct part of a set of facts that could be a cause the injury? and (2) Is the wrongful conduct part of a set of facts that did cause the injury? In most instances, the second inquiry

damage to a building or other property. Resurfice material contribution necessarily assumes, or requires proof on the balance of probability, that the negligence has the capability of causing the injury in issue. In tort, causation doctrines are based on the premise that the conduct or event has the capability of being a part of a cause of the alleged injury. If the conduct in issue does not have the capability of being a part of the cause of the injury to that plaintiff, then there can never be a duty of care in respect of that conduct and that injury to that plaintiff, so the causation question never arises. See generally Richard W. Wright, "Causation, Responsibility, Risk, Probability, Naked Statistics, and Proof: Pruning the Bramble Bush by Clarifying the Concepts, (1988) 73 lowa L. Rev. 1001 at 1046 ("Thus, to prove that a specific condition was a cause of a particular result, one obviously must establish ... that some credible causal generalization links conditions of that type to results of that type.") and The Federal Judicial Centre, Reference Manual on Scientific Evidence, 3d ed., (Washington, D.C.: National Academies Press, 2011) at xiv ("general causation [asks] ... is a particular stimulus known to produce a particular reaction [?] ... specific causation [asks] ... did a particular stimulus cause a particular consequence in a specific instance[?]") [Words in brackets and punctuation added.]

5 Some of the implications in the statements in Resurfice, supra note 1 at paras. 21-23, about the but-for test are problematic if the Court meant what the text of Resurfice seems to mean. I discuss this briefly in Chapter 3.1, at the text accompanying notes 55-64. Detailed discussion is outside the scope of this paper. See generally David Cheifetz, "Tales of Sound and Fury: Factual Causation in Tort after Resurfice" in 2008 LSUC Special Lectures (Toronto: Irwin Law Book, 2009) 201 [Cheifetz, "Tales"] and David Cheifetz, "Not Clarifying Causation" in Causation in Tort II (Vancouver, Continuing Legal Education Society of British Columbia, 2011) for discussion of the effect of Resurfice on the meaning of the but-for test.

6 Paraphrasing the explanation of the factual causation inquiry in R. v. Nette, [2001] 3 S.C.R. 488 at para. 44,2001 SCC 78 [Nette]. Nette's explanation is: "Factual causation, as the term implies, is concerned with an inquiry about how the victim came to his or her death, in a medical, mechanical, or physical sense, and with the contribution of the accused to that result." The quotation should be understood to mean that that factual causation is concerned with how injury occurred in a scientific sense; that is, there must be some objective, factual, basis to support the conclusion that there is a causal connection between the wrong and the injury. It should not be understood as also suggesting that science's threshold for what is sufficient to establish that causal connection need be law's threshold. (Email from Lewis Klar dated June 13, 2012, on file with author.) The level of certainty that law requires for a decision that factual causation exists, in a scientific sense, is less than that which science would require for the same decision. See infra, text accompanying note 319. 
is the contentious issue. "Where factual causation is established, the remaining issue is legal causation." ${ }^{8}$ Legal causation is "based on concepts of moral responsibility and is not a mechanical or mathematical exercise." ${ }^{9}$ Legal causation is "a narrowing concept which funnels a wider range of factual causes into those which are sufficiently connected to a harm to warrant legal responsibility." ${ }^{10}$ Resurfice material contribution is an example of legal causation in that sense, even though it allows a finding of legal causation in circumstances where the finding could not have been made validly before Resurfice. ${ }^{11}$

${ }^{7}$ For example, there will usually not be an issue about whether a collision involving a human being and a heavy object moving at a sufficient speed could cause some physical injury to the human being. The contentious issue will usually be whether the collision was part of a set of facts that did cause the alleged injury. On the other hand, both issues may be contentious where the allegation is the effect of an alleged toxin on human health.

8 Ibid.

9 Ibid. at para. 83. Nette's explanations were adopted by the Supreme Court in R v. Maybin, 2012 SCC 24.

${ }^{10} R$ v. Maybin, ibid. at para. 9 [emphasis added].

${ }^{11}$ See Chapter 3.2. 


\section{The Decision in Resurfice}

Ralph Hanke was an employee in an Edmonton, Alberta, arena. One of his duties was to operate the ice-resurfacing machines. One of the machines was powered by gasoline. The filler ports for the gasoline tank and the hot water tank were on the same side. The hot water tank had to be refilled. Somebody put the hose for the hot water into the gas tank. Hanke did not realize this. He opened the tap. The hot water caused some of the gasoline in the tank to vaporize. The vapour escaped through open filler port and rose to the ceiling. There was a working, open-flame, natural gas heater hanging from the ceiling. The flame ignited the vapour. Hanke was badly hurt in the resulting explosion.

Hanke sued the manufacturer and the vendor of the machine. He alleged the machine was negligently designed in having both tank ports on the same side without adequate differentiation, and that this negligence was a cause of the accident. The trial judge found that the machine was not negligently designed. The trial judge applied the but-for test to determine causation. He held that Hanke was not confused by the location of the filler ports. The trial judge held that the but-for cause of the accident was Hanke's own carelessness. ${ }^{12}$

The Alberta Court of Appeal set aside the trial decision and ordered a new trial. The court held the trial judge had erred in applying the but-for test. The court held the Athey material contribution test should have been applied. The Supreme Court of Canada allowed the defendants' appeal and dismissed the action. The Court held the trial judge was correct in applying the but-for test. ${ }^{13}$

If that had been all that occurred in Resurfice, the decision might have produced some explanation of the meaning of the material contribution test that most members of the Canadian legal profession, including its judges, assumed that the Supreme Court had

12 Ibid. at paras. 1-5.

13 Ibid. at paras. 4, 30. The Alberta Court of Appeal also disagreed with the trial judge's view that the design was not negligent. The Supreme Court held that the Court of Appeal erred in interfering on this issue, too: ibid. paras. 6-12. 
established in Athey v. Leonati. ${ }^{14}$ Athey stated: "[t]he 'but for' test is unworkable in some circumstances, so the courts have recognized that causation is established where the defendant's negligence 'materially contributed' to the occurrence of the injury." ${ }^{15}$ However, Athey used the but-for test. Athey did not use this alternative test that later cases, not Athey, labelled a "material contribution" test. Athey did not provide any label for the alternative approach. Athey did not explain the meaning of "unworkable". Athey did not provide examples of instances in which the but-for test would be "unworkable". And, Athey did not explain the alternative approach to proof of factual causation beyond the advice that a factual cause "materially contributed to the occurrence of the injury" if it made more than a de minimis contribution to the occurrence of the injury. ${ }^{16}$

In Resurfice, the Supreme Court held the Alberta Court of Appeal erred in holding the applicable test for factual causation was Athey material contribution. ${ }^{17}$ The Court reiterated that the but-for test is applicable to injury in cases where the causative event is the combination of multiple necessary causes.

First, the basic test for determining causation remains the "but for" test. This applies to multi-cause injuries. The plaintiff bears the burden of showing that "but for" the negligent act or omission of each defendant, the injury would not have occurred. Having done this, contributory negligence may be apportioned, as permitted by statute.

This fundamental rule has never been displaced and remains the primary test for causation in negligence actions. As stated in Athey $v$. Leonati, at para. 14, per Major J., "[t]he general, but not conclusive, test for causation is the 'but for' test, which requires the plaintiff to show that the injury would not have occurred but for the negligence of the defendant". Similarly, as I noted in Blackwater v. Plint, at para. 78,

\footnotetext{
14
}

Athey v. Leonati, [1996] 3 S.C. R. 458, 1996 CanLII 183 [Athey cited to S.C.R.]. A leading Canadian tort treatise asserts that Athey should not have been interpreted as establishing a separate test for factual causation: see infra at the text accompanying note 145. A number of British Columbia appellate decisions since Resurfice have made the same claim: see infra at the text accompanying note 144.

15 Ibid. at para. 15 .

16 Ibid. at 16. "A contributing factor is material if it falls outside the de minimis range."

17 Resurfice, supra note 1 at paras. 18-22, 29. 
"[t]he rules of causation consider generally whether 'but for' the defendant's acts, the plaintiff's damages would have been incurred on a balance of probabilities." ${ }^{18}$

The Court held "the Court of Appeal erred in failing to recognize that the basic test for causation remains the 'but for' test. It further erred in applying the material contribution test in circumstances where its use was neither necessary nor justified." ${ }^{19}$ Although the Court did not use the "unworkable" term, the Court has to be understood to have held that there was nothing about the facts of Resurfice that made the but-for test "unworkable" in Athey terms. Thus, the Alberta Court of Appeal was wrong in asserting that the but-for test was made unworkable and the Athey material contribution test applicable merely because there was more than one potential cause for the explosion. ${ }^{20}$

In holding the applicable test for factual causation was the Athey material contribution test, the Alberta Court of Appeal referred to a passage from Walker Estate v. York Finch General Hospital. ${ }^{21}$ Taken out of context, the Walker Estate passage does assert that a material contribution test is to be used to determine factual causation whenever the injury may have more than one cause. ${ }^{22}$ However, the Court of Appeal did not quote the passage in Walker Estate. It is:

18 Ibid. at paras. 21-22.

19 Ibid. para. 29.

20

Ibid. at paras. 18-22. Resurfice has a "multi-cause" injury in the sense that the explosion was the consequence of cumulatively necessary multiple causes. Hanke's injury has only one cause: the explosion. The injury in Athey, however, is a multi-cause injury in the sense the plaintiff had been injured twice, in unrelated incidents, before the occurrence of the third event. The combination of the first two events and the third is the cumulative cause of the Athey injury. The statement in Resurfice that the but-for test "applies to multi-cause" injuries should be understood to refer only to cases such as Athey where the injury is the consequence of cumulatively necessary prior events or conditions, or Resurfice where a number of events were cumulatively necessary to produce the event which caused the explosion and fire that injured the plaintiff.

21 [2001] 1 S.C.R. 647, 2001 SCC 23 aff'g on other grounds (1999), 43 O.R. (3d) 461, 1999 CanLII 2158 (C.A.), rev'g (1997), 39 C.C.L.T. (2d) 1 (Ont. S.C.J.) [Walker Estate cited to S.C.R. unless otherwise indicated].

22 Resurfice, supra note 1, 2005 ABCA 383 at para. 14. 
The general test for causation in cases where a single cause can be attributed to a harm is the "but-for" test. However, the but-for test is unworkable in some situations, particularly where multiple independent causes may bring about a single harm. ${ }^{23}$

The court wrote, instead:

Where there is more than one potential cause, the 'material contribution' test should be used: Walker Estate v. York Finch General Hospital, [2001] 1 S.C.R 647 at 679-80. As the Appellant's act of inserting or leaving the hose in the gasoline tank may have contributed, the 'material contribution' test should have been used. The 'but for' test was unworkable in these circumstances." 24

Walker Estate had not explained why the mere fact that the injury might be caused by multiple independent causes might make the but-for test unworkable. Walker Estate also did not explain whether the Supreme Court meant multiple independent causes all of which are cumulatively necessary for the occurrence of the injury or multiple independently sufficient causes. ${ }^{25}$ Neither did the Alberta Court of Appeal. Beyond citing Walker Estate, the

23 Walker Estate, supra note 21 at para. 87 [emphasis added]. The but-for test was held to be workable and satisfied in Walker Estate, supra at para. 97.

24

Resurfice, supra note 1, 2005 ABCA 383 at para. 14.

25

It is widely accepted that the but-for test cannot be validly applied to instances of injury caused by multiple sufficient causes. The label commonly used, in causation literature, for instances of multiple sufficient causes is "duplicative causation". Injury caused where there is duplicative causation is described as "overdetermined" injury. In instances of duplicative causation, each of the causes is sufficient (together with the background facts that are necessary for it to be sufficient, at least some of which will be common to all of the sufficient conditions) but none of the sufficient causes can be described as necessary since any one of the other sufficient causes will suffice as a cause. See generally Lewis Klar, Tort Law, 4th ed. (Toronto: Carswell, 2008) at 430, n. 11, and at 454-55 [Klar, Tort Law]. McLachlin C.J. discussed this issue in her 1987 article, Hon. B. McLachlin, "Negligence Law Proving the Connection" in Nicholas Mullany and Allen M. Linden, eds., Torts Tomorrow, A Tribute to John Fleming (Sydney: LBC Information Services, 1998) 16 at 18-23 [McLachlin, "Proving the Connection"]. It is also implicit in McLachlin J.'s (as she then was) dissent in Sunrise Co. v. Lake Winnipeg (The), [1991] 1 S.C.R 3, 1991 CanLII 107 [Sunrise]. If the results are to be seen as correct, then Walker Estate, supra note 21, necessarily, and Myers v. Peel County Board of Education, [1981] 2 S.C.R. 21, 1981 CanLII 27 [Myers], arguably, have to be understood as instances where the Supreme Court recognized the existence of duplicative causation. A sufficient condition test for factual causation presumes the possible existence of another sufficient cause. The Court's statements in Myers, ibid., [1981] 2 S.C.R. 21 at 35, that the plaintiff did not have to prove, on the balance of probability, that the presence of crash mats or teacher supervision "would have prevented" the injury can be correct only under a sufficient condition test, unless the Court is to be to understood to have made the trite statement that the plaintiff did not have to prove factual causation was a certainty. Neither statement is valid under a necessary condition test based on the balance of probability; that is, the but-for test. The absence of one or the other of crash mats or teacher supervision would have been irrelevant if both events were negligent. The existence of one or the other of these events would have been relevant if one of them was not the result of negligence. The best available candidate for a test that validly handles all types of currently known causal connections - causal necessity and causal sufficiency without necessity - is the NESS test. Klar, Tort Law, ibid. at 430, n. 11, provides a brief outline of 
Court of Appeal did not attempt to explain why the mere fact there was the potential for more than one cause made the but-for test necessarily unworkable. The court did not explain why the mere fact that Hanke's action "may have contributed" to how the explosion occurred made the but-for test unworkable.

Athey should have made the Alberta Court of Appeal panel reconsider their conclusion that the but-for test was unworkable. Athey had multiple independent causes which, in fact, brought about a single injury: the disc herniation. Athey did not have multiple, independently sufficient, causes. All of the two motor vehicle accidents and the pre-existing back-condition were cumulatively necessary. ${ }^{26}$ The Supreme Court did not have any difficulty in applying the but-for test in Athey. The likely explanation for why the Alberta Court of Appeal missed this is the manner in which the Athey material contribution test came to be used in the common law courts of the provinces and territories.

There is no doubt that Athey used the but-for result, notwithstanding the Supreme Court's use of the "material contribution" phrase, four times, in the latter part of the Athey reasons. ${ }^{27}$ However, this was in the context of the Court's explanation of why the trial judge's findings of fact satisfied the requirements of the but-for test. ${ }^{28}$ The Court explained:

If it was necessary to have both the accidents and the pre-existing back condition for the herniation to occur, then causation is proven, since the herniation would not have occurred but for the accidents. Even if the accidents played a minor role, the defendant would be fully liable because the accidents were still a necessary contributing cause. ${ }^{29}$

The Athey decision is an application of this principle. The Court held the trial judge had found it was necessary to have both the accidents and the pre-existing back condition. "The

the NESS test. The seminal article is Richard W. Wright, "Causation in Tort Law" (1985), 73 Calif. L. Rev. 1737 [Wright, "Causation"].

26 The Athey reasons contain the incorrect statement that the exercise "incident" was not a cause but an effect: see supra note 4 at para. 39. The herniation was the effect. The exercise was part of the cause.

27 Athey, supra note 14 at paras. 41, 44 and 45.

28 Ibid. at paras. 39-53.

29 Ibid. at para. 41.2 [emphasis in original]. 
findings of the trial judge indicate that it was necessary to have both the pre-existing condition and the injuries from the accidents to cause the disc herniation in this case." ${ }^{30}$ This is a but-for conclusion, nothing more.

The sole reference to Athey in the Alberta Court of Appeal's reasons in Resurfice is the quotation containing Athey's statement of a material contribution test. ${ }^{31}$ The Alberta Court of Appeal panel then used their apparent understanding of the Walker Estate dictum, quoted above, $^{32}$ to justify the conclusion that the Athey material contribution test applied, not the but-for test. ${ }^{33}$ Without explaining why, the Court of Appeal ignored the explicit statements in Walker Estate that the version of a material contribution test described in Walker Estate was restricted to cases arising out of negligent screening of blood donors. ${ }^{34}$ The explanation is, undoubtedly, that judges and commentators alike had ignored this limitation when referring to Walker Estate's use of material contribution, either by itself or in conjunction with Athey.

The Alberta Court of Appeal's statement that the but-for test was made unworkable by the mere presence of more than one potential cause explains the Supreme Court's decision to grant leave and, ultimately, to set aside the Court of Appeal's decision.

The Court of Appeal found, correctly, that the trial judge had applied a "but for" test in determining causation, stating, "[t]he thrust of the reasoning is that "but for' the Appellant putting or leaving the hose in the gasoline tank, the explosion would not have occurred" (para. 12). Referring to the observation in Athey v. Leonati ... at para. 15, that the "but for" test "is unworkable in some circumstances", the Court of Appeal concluded that this was such a case and that the trial judge should have used a "material contribution" test instead of the "but for" test (para. 14).

The Court of Appeal erred in suggesting that, where there is more than one potential cause of an injury, the "material contribution" test must be used. To accept

30

Ibid. at para. 43 [emphasis in original].

31

Resurfice, supra note 1, 2005 ABCA 383 at para. 13.

32 supra at note 23.

${ }^{33}$ See the text accompanying note 24 .

34 Walker Estate, supra note 21 at paras. 87-88. 
this conclusion is to do away with the "but for" test altogether, given that there is more than one potential cause in virtually all litigated cases of negligence. If the Court of Appeal's reasons in this regard are endorsed, the only conclusion that could be drawn is that the default test for cause-in-fact is now the material contribution test. This is inconsistent with this Court's judgments in Snell v. Farrell ...; Athey v. Leonati, at para. 14; Walker Estate v. York Finch General Hospital ... at paras. 87-88, and Blackwater v. Plint ... at para. $78 .^{35}$

The Supreme Court's protestations notwithstanding, the Alberta Court of Appeal applied the meaning of an explicit statement in Walker Estate, provided one ignored the explicit limitation to cases arising out of negligent screening of blood donors as judges had been doing.

The Supreme Court was correct in stating that "[i]f the Court of Appeal's reasons in this regard are endorsed, the only conclusion that could be drawn is that the default test for cause-in-fact is now the material contribution test". ${ }^{36}$ However, the Court should have acknowledged that the Alberta Court of Appeal was relying on what seemed to be the judicially accepted understanding of Walker Estate's explanation of the meaning of Athey's "unworkable". The Supreme Court ignored the fact that, unless the Court of Appeal was prepared to distinguish Walker Estate, the Court of Appeal was bound by what it thought Walker Estate meant. The Walker Estate material contribution ratio was not obiter. Even if it were, the limitation on its use was still binding. ${ }^{37}$ It might be that the Supreme Court's

35

Resurfice, supra note 1, paras. 18-19 [citations omitted]. See Mizzi v. Hopkins (2003), 64 O.R. (3d) 365 at paras. 13, 26-33, 2003 CanLII 52145 (C.A.) for another appellate view of the scope of Athey material contribution which is almost as wide as the Alberta Court of Appeal's. Mizzi asserts the Athey material contribution test applies whenever it is alleged the plaintiff has prior conditions, or was involved in prior incidents, which were also a cause of the injury in respect of which the plaintiff sues. The Court of Appeal's authorities were Athey and Walker Estate. Mizzi referred to the same pages in Walker Estate as the Alberta Court of Appeal did in Resurfice. Mizzi has not been referred to by the Ontario Court of Appeal for this proposition since Resurfice. The comments of the trial judge in the post-Resurfice decision in Frazer v. Haukioja, 2008 CanLII 42207 at para. 214 (Ont. S. C. J.) aff'd on other grounds 2010 ONCA 249 are also proof that, in Ontario, the Athey material contribution was becoming become the default test in cases having factually complicated or otherwise difficult causation questions. The trial judge held that the plaintiff had satisfied the but-for test. The trial judge stated that the Athey material contribution test "might" have been used before Resurfice to produce the same result (ibid.). The Court of Appeal did not discuss this comment and the Mizzi reasons contain nothing relevant to it.

36

Resurfice, supra note 1 at para. 19.

37

It was not obiter. There is an extensive discussion of the binding or merely persuasive status of Supreme Court obiter rulings of law in R. v. Henry, [2005] 3 S.C.R. 609 at paras. 52-57, 2005 SCC 76. 
apparent preference to avoid discussion of the meaning of Walker Estate - shown by the statement that it was not going to review causation jurisprudence in depth ${ }^{38}$ - explains why the Court stated only that the Court of Appeal had misunderstood Athey, not Athey and Walker Estate. In any event, the Supreme Court mentioned Walker Estate only as part of the list of cases the Court cited as having established that the but-for test, not a material contribution test, was the default test for factual causation. ${ }^{39}$

The Supreme Court could have limited the Resurfice reasons to an explanation of why the trial judge had applied the but-for test correctly. The Court did not. Resurfice concludes with a discussion of method by which a plaintiff may be able, in some cases, to satisfy the causation requirements of a cause of action in negligence even though the plaintiff cannot establish factual causation on the balance of probability. ${ }^{40}$ While Resurfice calls this approach "a material contribution test", it is not a restated version of the Athey material contribution test. The discussion of the conditions for this version of a material contribution test is not a discussion of the meaning of Athey's "unworkable". Apart from the fact that Resurfice does not suggest it is, the primary reason that the Resurfice version of material contribution test cannot be the Athey version is that the Athey version (whatever it meant) requires proof of factual causation on the balance of probability.

The Supreme Court asserted, in Resurfice, that the principles of the new version of a material contribution test "emerge from the cases". ${ }^{41}$ They do not. The principles of Resurfice material contribution are explicitly inconsistent with earlier Supreme Court of

\footnotetext{
38 Resurfice, supra note 1 at para. 20.

39 Ibid. at para. 19.

40 Ibid., paras 24-29. See Chapter 3.2.
}

41 Ibid. at para. 20. The Court did not set out any of those cases, unless the list includes the two cases the Court used in its two examples: Cook v. Lewis, [1951] S.C.R. 830, 1951 CanLII 26 aff'g [1950] 4 D.L.R. 136, [1950] 2 W.W.R. 451 (B.C.C.A.) [cited to S.C.R. unless otherwise indicated] and Walker Estate, supra note 21. That assumption is problematic at best. 
Canada decisions. The list predates Snell v. Farrell, ${ }^{42}$ but there is no need to go beyond Snell. ${ }^{43}$ The farthest the earlier cases ever went was Walker Estate's sufficient condition version of a material contribution test, even limited as it was to cases arising out the negligent screening of blood donors. ${ }^{44}$ Walker Estate states:

In cases of negligent donor screening, it may be difficult or impossible to prove hypothetically what the donor would have done had he or she been properly screened by the CRCS. The added element of donor conduct in these cases means that the butfor test could operate unfairly, highlighting the possibility of leaving legitimate plaintiffs uncompensated. Thus, the question in cases of negligent donor screening should not be whether the CRCS's conduct was a necessary condition for the plaintiffs' injuries using the "but-for" test, but whether that conduct was a sufficient condition. The proper test for causation in cases of negligent donor screening is whether the defendant's negligence "materially contributed" to the occurrence of the injury. ${ }^{45}$

However, the Walker Estate sufficient condition version of material contribution still requires proof of factual causation on the balance of probability. ${ }^{46}$

Resurfice also contains explicit or implicit propositions relating to the use of the but-for test and proof of factual causation on the balance of probability. This aspect of Resurfice is not discussed except to the extent these propositions may affect the interpretation of the Resurfice material contribution doctrine. These propositions include at least the following.

1. The basic, default, test for determining factual causation in negligence is the but-for test. $^{47}$

42 [1990] 2 S.C.R. 311, 1990 CanLII 70 [Snell cited to S.C.R.].

43 The cases are listed infra in note 121. See also Cheifetz, "Tales", supra note 4 at 218-19, at the text accompanying n. 90.

44

Allen M. Linden \& Bruce Feldthusen, Canadian Tort Law, 9th ed. (Toronto: LexisNexis, 2011) [Linden, Canadian Tort Law] at 124, at the text accompanying n. 81, acknowledges that Walker Estate is a sufficient condition decision.

45

Supra note 21 at para. 88 [emphasis added]. "CRCS" is the Canadian Red Cross Society.

${ }^{46}$ This is implicit in Walker Estate, ibid. at paras. 87-88 and 97. The Supreme Court did not expressly say that the standard of proof is the balance of probability. There is no discussion of the standard of proof at all. However, the Court refers to Athey. Athey holds that the standard of proof for all past events is the balance of probability. See Athey, supra note 14 at paras. 27-28.

${ }^{47}$ Resurfice, supra note 1 at paras. 21.29 
2. The but-for test is not conclusive. ${ }^{48}$

3. The but-for test "applies to multi-cause injuries." 49

4. The general rule is the plaintiff has the burden of proof of establishing, on the balance of probability, the injury would not have occurred but-for the aspect of the conduct of the defendant which makes that conduct negligent. ${ }^{50}$

5. The rule in Cook v. Lewis ${ }^{51}$ and the Walker Estate sufficient-condition material contribution test still exist as tests for proof of factual causation on the balance of probability. $^{52}$

6. The but-for test requires the plaintiff prove more than just a necessary connection, on the balance of probability, between the defendant's negligence and the injury. The necessary connection must be a "substantial connection". ${ }^{53}$

7. The Athey material contribution test is defunct. ${ }^{54}$

8. Resurfice has no effect on the content of remoteness (proximate cause) jurisprudence.

48 Ibid. at para. 22

49 Ibid. at para. 21.

50 Ibid.

${ }^{51}$ Supra note 41. Resurfice does not disavow, or even discuss, the basis of the decision in Cook v. Lewis.

52 See the text accompanying notes 44-46 for the discussion of the Walker Estate sufficient condition version of a material contribution test for proof of factual causation on the balance of probability.

${ }^{53}$ Resurfice, supra note 1 at para. 23.

54 At least for cases that do not have multiple sufficient causes. 


\section{Consequences of Resurfice}

\subsection{Summary}

If the Resurfice reasons are given their apparent meaning, the first major consequence is that, with one exception, the but-for test is now the only available test for proof of factual causation, on the balance of probability, in litigation alleging injury caused by negligence. The one exception is where the injury arises out of negligent screening of blood donors. It is wrong to interpret Resurfice to have replaced the Walker Estate version of material contribution with the Resurfice version of material contribution for cases arising out of the negligent screening of blood donors, so that those plaintiff are never required to establish factual causation on the balance of probability. In those cases, the court will have to first decide whether the plaintiff is able to establish factual causation under the Walker Estate version of material contribution. If the plaintiff fails, the court will then have to consider whether the reason for that failure is capable of triggering Resurfice material contribution. ${ }^{55}$

The apparent instruction that the but-for test is, now, the only available method for by which the existence of factual causation may be validly determined is problematic for a number of reasons beyond that it is inconsistent with the existence of Walker Estate material contribution. It is sufficient to mention some of these other reasons because they must underlie the Supreme Court's acknowledgment that the but-for test is "not conclusive". Resurfice does not explain why the but-for test is not conclusive. It does nothing more than quote Athey. ${ }^{56}$ The but-for test cannot be conclusive if the Athey material contribution test, properly understood, was a valid alternative method of establishing the existence of factual causation, on the balance of probability, in circumstances to which the but-for test is not validly applicable.

\footnotetext{
${ }^{55}$ This version is summarized supra at the text accompanying notes $44-46$ and discussed in detail in Chapter 3.2 .

${ }^{56}$ Resurfice, supra note 1 at para. 22.
} 
The but-for test is not conclusive because there are at least two known instances of factual causation, which can be established on the balance of probability, where the but-for test cannot validly identify any of the factual causes. ${ }^{57}$ Both are instances of duplicative causation: where the multiple sets of factors ${ }^{58}$ which are the causes of the injury are all independently (of each other) sufficient so that each one is, individually, not necessary. One of these instances is where the negligence is necessary for the causal sufficiency of a set of which it is a part, but that set is not necessary because there are other sufficient causal sets which do not include the negligence. The other is instances where there are multiple separate incidents of negligence by different people where none of the separate incidents are individually sufficient to cause the injury and each of the incidents can be combined with fewer than all of the other incidents to create a causally sufficient set. ${ }^{59}$ What is now the test for proof of factual causation on the balance of probability, in these instances, if it is not the but-for test because it cannot be the but-for test. ${ }^{60}$

The reason why the but-for test fails - why it is impossible to validly use the but-for test - in instances of duplicative causation has nothing to do with insufficient evidence. It is a consequence of the definition of the but-for text: the requirement of "necessity". In applying the but-for test, the court first decides if the defendant's negligence could be a factual cause on the balance of probability. It is only if the court concludes that the negligence could be a factual cause on the balance of probability that the court then undertakes the but-for counterfactual analysis which determines whether the injury probably would have occurred even without the negligence. It is the counterfactual aspect of the but-for analysis that

\footnotetext{
57 Another reason why the but-for test is not conclusive is that, even if the negligence satisfies the but-for test, it must still satisfy the proximate cause or remoteness requirement: see generally Klar, Tort Law, supra note 25 , c. 12. It is not clear whether the Court was referring to this aspect of causation jurisprudence in Resurfice when it stated that the but-for test is not conclusive. The better view is that it was not. 
produces the conclusion that the defendant's negligence was or was not necessary for the injury to have occurred. "[I]f the defendant's conduct can be shown to have been a necessary cause of the plaintiff's harm ... the but for test is satisfied. Conversely, if the plaintiff fails to prove this on the balance of probabilities, the causal connection has not been established." 61

Another problem that requires brief mention is the apparent conflation, in Resurfice, of the but-for, factual causation, inquiry and the remoteness (proximate cause) inquiry. Resurfice states:

The "but for" test recognizes that compensation for negligent conduct should only be made "where a substantial connection between the injury and the defendant's conduct" is present. It ensures that a defendant will not be held liable for the plaintiff's injuries where they "may very well be due to factors unconnected to the defendant and not the fault of anyone": Snell v. Farrell, at p. 327, per Sopinka J. ${ }^{62}$

As Athey noted, negligence which is a necessary cause is a but-for cause even if the role the negligence played is minor. ${ }^{63}$ If Resurfice, by using "substantial connection", meant to say that a necessary cause is not a but-for factual cause unless it is also amounts to a substantial connection, then it conflated the factual causation and remoteness (proximate cause) inquiries. ${ }^{64}$ The better conclusion is that the Supreme Court did not intend to conflate the separate inquiries. As mentioned, the Supreme Court has explained that legal causation is "a narrowing concept which funnels a wider range of factual causes into those which are sufficiently connected to a harm to warrant legal responsibility." 65 "Sufficiently connected" and "substantial connection" have to be understood as synonyms.

\footnotetext{
${ }^{61}$ See Klar, Tort Law, supra note 25 at 429-30; Linden, Canadian Tort Law, supra note 44 at 121.

62 Resurfice, supra note 1, para. 23.

${ }^{63}$ Athey, supra note 14 at para. 41.2, quoted supra at note 29.

64 The British Columbia Court of Appeal has used this passage in Resurfice to equate a but-for cause with Athey's use of "materially contributed" (Athey, supra note 14 at para. 15) by holding that "substantial connection" is synonymous with "materially contributed". See the cases listed infra in note 144.

${ }^{65}$ R. v. Maybin, supra note 9 at para. 9 [emphasis added].
} 
The second major consequence of Resurfice is that it is no longer the case that liability for negligence always requires that the plaintiff show, on the balance of probability, that the negligent conduct for which a defendant may be held liable was a factual cause of the plaintiff's injury. ${ }^{66}$ Resurfice created a new causation doctrine, available only in exceptional cases, under which a plaintiff is able to satisfy the causation requirements in a claim for injury alleged to have been caused by the negligence of the defendant, even though neither plaintiff nor defendant is able to prove or disprove factual causation on the balance of probability. The stated rationale for this doctrine is fairness and justice. ${ }^{67}$ The Supreme Court described this doctrine as a "material contribution" test. ${ }^{68}$ The Court did not explain why it chose a label that was already taken and which described a method for proof of factual causation on the balance of probability. The Resurfice version of material contribution is based on the possibility of factual causation as a result of the negligence of the defendant, not the probability of factual causation. ${ }^{69}$ The application of the doctrine does not produce a decision that the negligence did cause the injury. Instead, where the requirements of the Resurfice material contribution are satisfied, the causation requirements of the cause of action are deemed to be satisfied despite the finding that factual causation was not established on the balance of probability. ${ }^{70}$

${ }^{66}$ Resurfice, supra note 1, paras. 24-28. See Chapter 3.2.

67 Resurfice, supra note 1 at para. 25.

68 Ibid.

69 See Chapter 3.2., particularly at the text accompanying notes 171-207. See also Klar, Tort Law, supra note 25 at 44; Russell Brown, “Material Contribution's Expanding Hegemony: Factual Causation after Resurfice Corp. v. Hanke" (2007) 45 Can. Bus. L. J. 432 at 445-449, particularly at 449: Resurfice "jettisoned [the] necessary connection between wrong and harm" [Brown, "Hegemony"]; and Cheifetz, "Tales", supra note 5 at 206-211. See however G.H.L. Fridman et al., The Law of Torts in Canada, 3d ed. (Toronto: Carswell, 2010) at 416 [Fridman, The Law of Torts In Canada].

70 See Chapter 3.1. 
Under Resurfice material contribution, (1) actionable injury, ${ }^{71}$ a duty of care, and breach of the duty, together with the possibility of factual causation created by that breach ${ }^{72}$ (2) may be enough, in exceptional circumstances, ${ }^{73}$ to satisfy the causation requirements of the cause of action in negligence (3) where it is impossible to prove or disprove factual causation on the balance of probability because of the current limits of scientific knowledge or analogous reasons, ${ }^{74}$ and (4) "it would offend basic notions of fairness and justice" to dismiss the plaintiff's action merely because factual causation could not be proved or disproved on the balance of probability. ${ }^{75}$ The meaning of the impossibility requirement is one the two keys to the scope of Resurfice material contribution. ${ }^{76}$ The other is the meaning of the fairness and justice requirement. ${ }^{77}$ The ambit of risk requirement is not useful in determining which cases are the exceptional cases to which Resurfice material contribution will apply. ${ }^{78}$ That element is an essential aspect of all negligence actions. There cannot be negligence without the creation of unreasonable risk. $^{79}$

The Resurfice version of material contribution is not the Athey material contribution test with clarified, more restrictive, requirements. It is a new doctrine. According to the

\footnotetext{
71 The mere fact of a duty of care does not mean that all injury caused by a negligent breach of that duty is actionable. For example, only some types of economic loss are actionable. See Russell Brown, Pure Economic Loss in Canadian Negligence Law (Toronto: LexisNexis Canada, 2011), c. 1 [Brown, Pure Economic Loss].

72

It is necessarily implicit in the ambit of risk requirement that the wrongful conduct could be a cause of the injury that occurred. If the wrongful conduct could not possibly be a cause, there could not be a duty. This seems to have been recognized in Clements (Litigation Guardian of) v. Clements, 2011 BCCA 581 at para. 45. The Resurfice material contribution doctrine "provides a basis for finding legal causation when there is a possibility that the defendant's negligent actions could have been a factual cause." [Emphasis in original.]

73

Resurfice, supra note 1 at para. 25.

74 Ibid. at para. 25. See Chapter 3.2.2.

75

Ibid., para. 25. See Chapter 3.2.4.

${ }^{76}$ See Chapter 3.2.2.

${ }^{77}$ See Chapter 3.2.4.

${ }^{78}$ See Chapter 3.2.3.

${ }^{79}$ See Klar, Tort Law, supra note 25 at t 647, n. 196. See Chapter 3.2.3 at the text accompanying notes $403-411$.
} 
jurisprudence preceding Resurfice, and taking Athey at its word, the Athey version was an alternative method for establishing factual causation on the balance of probability. ${ }^{80}$ Whatever Athey material contribution meant, whatever triggered that doctrine, it was not the impossibility of establishing factual causation on the balance of probability. It was the impossibility of validly using the but-for test to establish the existence of factual causation on the balance of probability. Before Resurfice, any action in tort in common law Canada should have been dismissed if the judge or jury concluded that it was impossible for the plaintiff to establish factual causation on the balance of probability whether the test applied to determine if factual causation had been established was but-for or Athey material contribution. Snell and Athey, and every Supreme Court of Canada decision after Athey and before Resurfice where causation in tort was mentioned, permit no other conclusion. Resurfice material contribution is not a method of establishing factual causation on the balance of probability. Under Resurfice material contribution, liability in negligence can now be based on a possibility less than a probability of factual causation. The restatement of the rationale for Resurfice material contribution that ends the Court's discussion of the second example permits no other valid conclusion. "Once again, the impossibility of establishing causation and the element of injury-related risk created by the defendant are central." 81

It is true that the apparent meaning of the paragraph that introduces the discussion of the version of a material contribution test in Resurfice is that the law the Court was about to explain was not new.

However, in special circumstances, the law has recognized exceptions to the basic "but for" test, and applied a "material contribution" test. Broadly speaking, the cases in which the "material contribution" test is properly applied involve two requirements. ${ }^{82}$

The insurmountable hurdle to taking this sentence to refer to the Athey version of material contribution is that the Athey test was understood to be a test for proof of factual causation

\footnotetext{
80 Athey, supra note 14 at para. 15. 
on the balance of probability. ${ }^{83}$ The discussion of causation in Athey $^{84}$ and subsequent case law permit no other meaning until the Supreme Court says otherwise.

The cases Athey cited in support of the existence of a material contribution test permit no other conclusion. ${ }^{85}$ While the list of cases includes McGhee v. National Coal Board, ${ }^{86}$ that has to be understood to be McGhee as explained by Wilsher v. Essex Area Health Authority ${ }^{87}$ and accepted by the Supreme Court in Snell. ${ }^{88}$ This is the robust and pragmatic approach to the use of but-for. It cannot be the "it is sufficient that the negligence materially increased the risk" explanation of McGhee revived by the House of Lords in Fairchild v. Glenhaven Funeral Services $L t d{ }^{89}$ when it overruled the Wilsher explanation of McGhee. Athey approved Snell. ${ }^{90}$ Athey cited both Snell and McGhee for the proposition that "[c]ausation is established where the plaintiff proves to the civil standard on a balance of probabilities that the defendant caused or contributed to the injury". ${ }^{91}$

Arguments to the effect that the Athey or Walker Estate versions of a material contribution test should be interpreted to allow a plaintiff to establish factual causation on a standard of proof of possibility less than probability were rejected in the four years preceding Resurfice

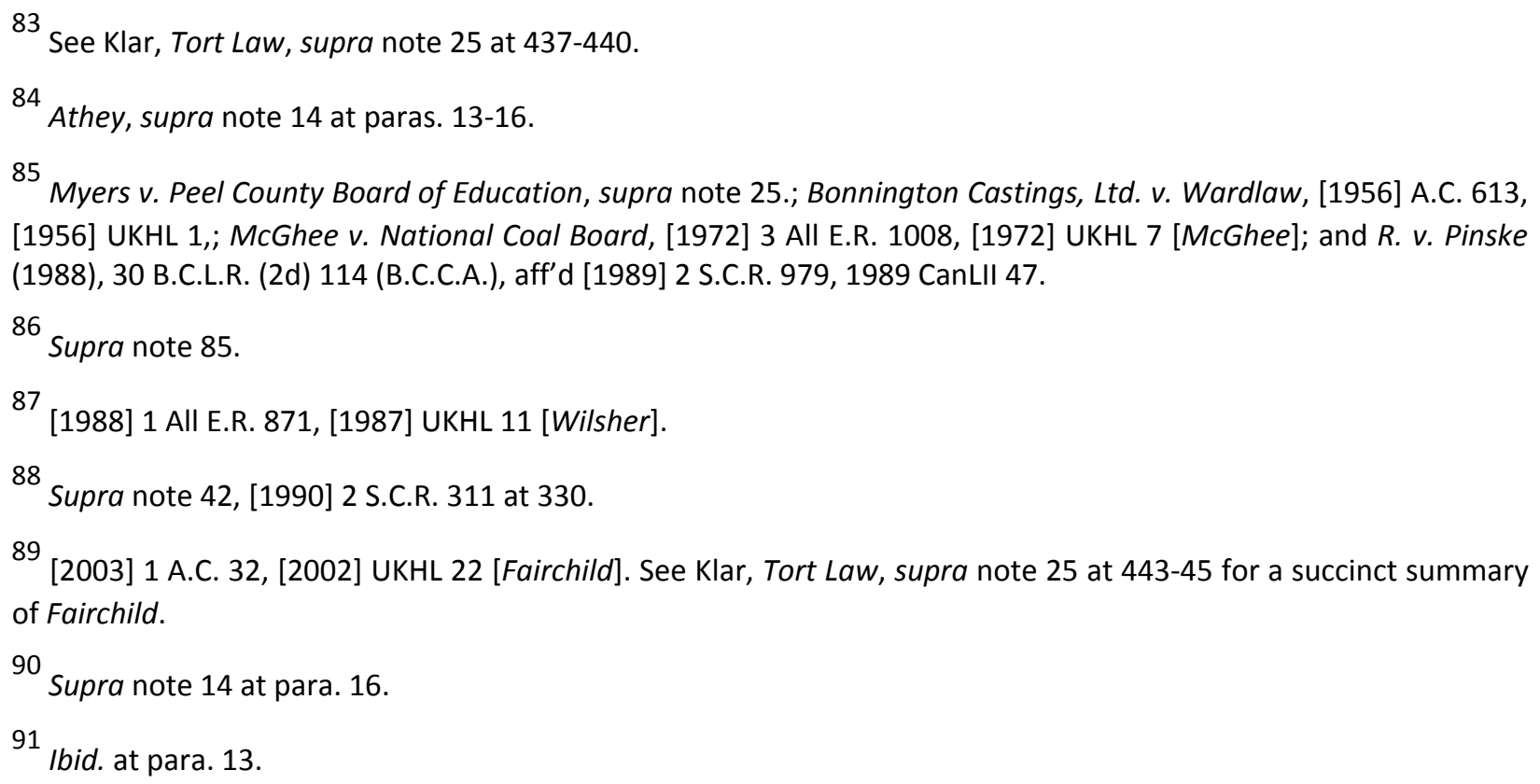


in appellate decisions in Ontario, ${ }^{92}$ British Columbia, $^{93}$ and Alberta. ${ }^{94}$ The Supreme Court denied leave to appeal in all of these cases. If the Resurfice material contribution principles already existed in Canadian common law, we might ask why leave was not granted. All of these cases were far better candidates for a discussion of the material contribution principles than was Resurfice.

The successful invocation of the Resurfice material contribution doctrine does not result in a decision that, on the balance of probability, the defendant's negligence was a factual cause of the plaintiff's injury. It produces a conclusion that the causation requirements of the cause of action are satisfied, so as to permit the imposition of liability assuming the plaintiff has satisfied the remaining requirements of the cause of action. ${ }^{95}$ Under Resurfice material contribution the negligence of the defendant is a sufficient cause if it could be possibly be a factual cause. "Could possibly be a factual cause" is the meaning of contribution. Material, then, must refer to some attribute of the possible factual cause which, for reasons of policy, justifies the conclusion that the possibility of factual causation is significant enough to

92 Cottrelle v. Gerrard (2003), 67 O.R. (3d) 737 at para. 23 , 2003 CanLII 50091 (Ont. C.A.) [Cottrelle]; leave to appeal refused [2004] 1 S.C.R. vii, 2004 CarswellOnt 1622. "[Plaintiff's counsel] submitted, however, that the evidence of a possibility, lower than a probability, that the respondent's leg might have been saved satisfied the test in Athey, and it seems likely that the trial judge proceeded on that same basis. I am unable to accept the correctness of that proposition." [Words in brackets added.] One of the arguments made in the leave to appeal application, in late 2006, in Aristorenas v. Comcare Health Services (2006), 83 O.R. (3d) 282, 2006 CanLII 33850 (ON C.A.) reversing 2004 CanLII 22088 (Ont. S.C.J.), leave to appeal refused 2007 CanLII 10550 (S.C.C.), was that possibility less than probability was enough. The leave application was filed in December 2006. The application went to the leave panel on February 26, 2007, after Resurfice was released.

93

Mooney v. British Columbia (Attorney General), 2004 BCCA 402 at para. 185, [2004] 10 W.W.R. 296, leave to appeal refused, [2005] 1 S.C.R. xiii [Mooney]. Walker Estate "should not be interpreted as espousing some lower threshold of causation in every case where the element of human behaviour introduces difficulties of proof " (ibid.).

94

Meyers v. Moscovitz, 2005 ABCA 114 at para. 31, 251 D.L.R. (4th) 114; leave to appeal refused [2005] 2 S.C.R. ix (note), 2005 CanLII 39649 [Meyers] stating that the ambit of risk test - defined to be a test under which causation could be established where a tortfeasor "created or materially contributed to a significant risk" - was considered and rejected by the Supreme Court" in both Snell, supra at the text accompanying note 88, and St.-Jean v. Mercier, [2002] 1 S.C.R. 491, 2002 SCC 15 [emphasis in original].

95

See Chapter 3.2. See the text accompanying notes 171-179 for the list of the British Columbia and Alberta authorities. See infra at the text accompanying notes 180-183 for the list of contrary Ontario Court of Appeal decisions. See also Cheifetz, "Tales", supra note 5 at 210-11. 
require the imposition of liability on the negligent defendant, assuming that all other requirements for the imposition of liability (other than proof of the probability of factual causation) are satisfied. ${ }^{96}$

Until Resurfice, the Athey material contribution test was used by the judges of Canada's common law jurisdictions as an alternative method of proving factual causation on the balance of probability. ${ }^{97}$ In setting out when the new version of material contribution might be available, Resurfice refers only to instances where the plaintiff is not able to use the butfor test to establish factual causation on the balance of probability. ${ }^{98}$ Resurfice does not refer to instances where the plaintiff is not able to establish factual causation on the balance of probability using either the but-for test or the Athey material contribution test. The Court did not explain why it did not refer to the Athey material contribution test. It makes no sense to assume the Court intended Resurfice material contribution to apply where Athey material contribution could be validly used by the plaintiff to prove factual causation on the balance of probability. Thus, the statement of the parameters of the Resurfice material contribution test has to be read as if one of its requirements is that factual causation cannot be proved or disproved, on the balance of probability, by whatever valid means exist. ${ }^{99}$

Next, the Supreme Court did not say it was explaining the meaning of Athey's "unworkable". The reasons do not use "unworkable" or any variation of the phrase in explaining the material contribution doctrine. The reasons do not discuss any of the cases purporting to explain the meaning of Athey's "unworkable". Athey is not mentioned in the part of the

\footnotetext{
96

See Chapter 3.2.5 for more discussion of the possible meaning(s) of "material" in the Resurfice material contribution doctrine.

97

See generally Klar, Tort Law, supra note 25 at 437-440.

98

Resurfice, supra note 1 at paras. 25, 26, 27, 28.

99

For Canadian purposes, the United Kingdom mesothelioma cases such as Fairchild, supra note 89, Barker v. Corus (UK) Plc., [2006] 2 A.C. 572, [2006] UKHL 20 [Barker v. Corus], and Sienkiewicz v. Greif (UK) Ltd., [2011] 2 A.C. 229, [2011] UKSC 10 [Sienkiewicz] dealing with the United Kingdom's version of a material increase in risk doctrine should be understood as cases where the evidence was not sufficient to identify any of the asbestos exposures which were the result of negligence as a probable cause.
} 
reasons that discuss material contribution. ${ }^{100}$ The only time "unworkable" is used is in the Court's description of the basis of the Alberta Court of Appeal's decision. ${ }^{101}$

The content of the examples to which the Resurfice material contribution test might apply is inconsistent with the suggestion that the Resurfice material contribution test is merely the Athey version of a test for factual causation on the balance of probability with restated prerequisites. The first example to which the Resurfice material contribution could apply is the assumed facts of Cook v. Lewis. ${ }^{102}$

One situation requiring an exception to the "but for" test is the situation where it is impossible to say which of two tortious sources caused the injury, as where two shots are carelessly fired at the victim, but it is impossible to say which shot injured him. ${ }^{103}$

However, those facts have a solution which the Court did not mention: the "rule in Cook v. Lewis". That solution predates Resurfice and is not a version of a material contribution test. It is the but-for test with the onus of proof shifted to the defendant to show, on the balance of probability, that the defendant's negligence was not a factual cause. ${ }^{104}$ The Supreme Court did not suggest that it was abolishing the rule in Cook v. Lewis. ${ }^{105}$

The better view of the rule in Cook v. Lewis is that it is limited to instances which have two tortfeasors where the injury must have been caused by one or the other. ${ }^{106}$ If there are more than two tortfeasors, so long as the injury could have been caused only by the conduct

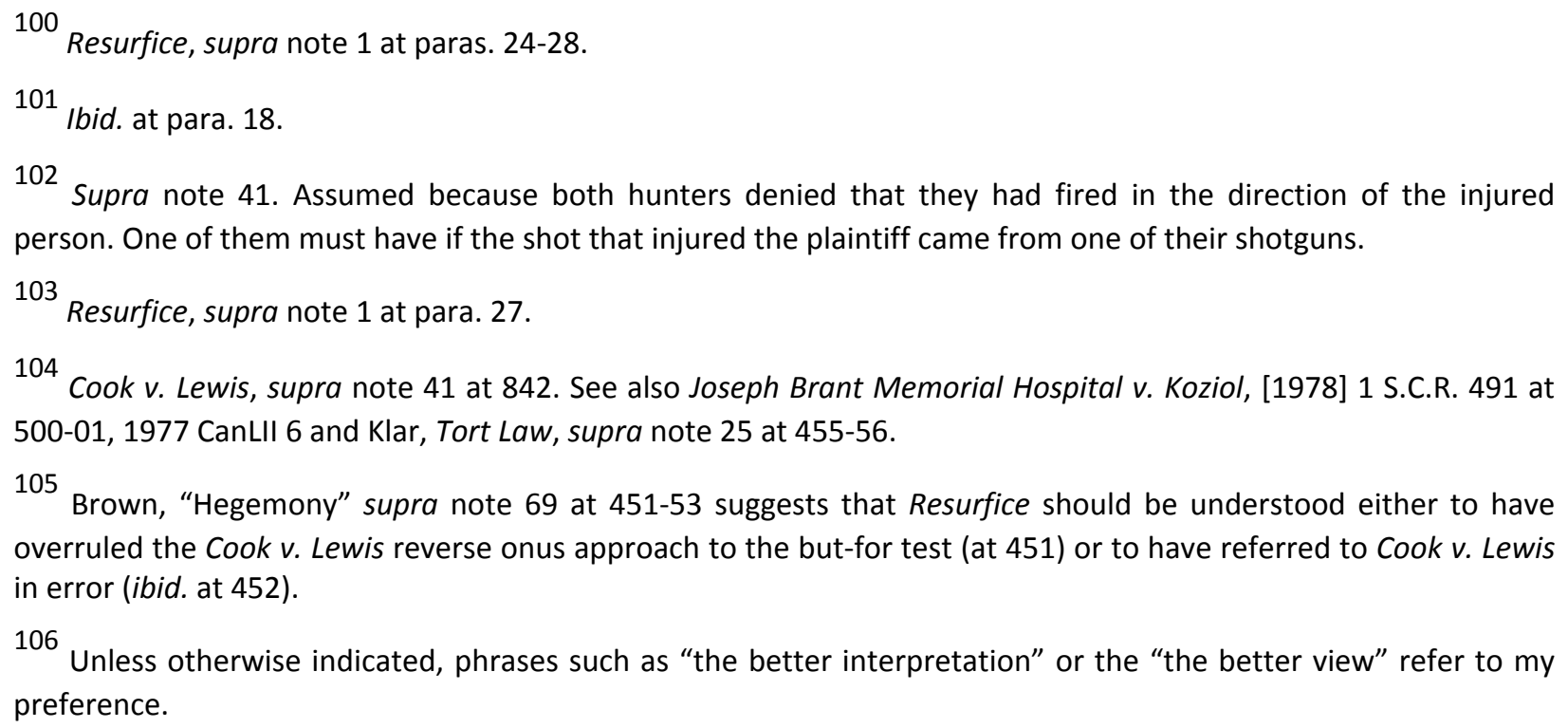


of one of them, the fact that one tortfeasor is able to establish, on the balance of probability, that that tortfeasor's negligence was not a factual cause does not determine the answer for the remaining tortfeasors. All it does is eliminate one of the tortfeasors. It would be contrary to principle to assume that the Court intended to limit the Resurfice version of material contribution to instances having no more than two tortfeasors. In addition, the premise of the rule in Cook $v$. Lewis is that the cause of the injury was the conduct of only one of the two tortfeasors, notwithstanding that both may be held liable if sued and neither tortfeasor is able to show that that tortfeasor's negligence was not a probable cause, on the balance of probability. ${ }^{107}$ However, the premise under the Resurfice version of material contribution is that the conduct of all negligent persons to whom it applies is a possible cause. Resurfice material contribution presumes that there may be more than one factual cause, whether the multiple causes are cumulative, duplicative or alternative. If the doctrine is applicable, all sued tortfeasors whose conduct is held to have been a possible cause may be held liable absent some other defence.

The second example in Resurfice of circumstances to which the material contribution test could apply also implies a new meaning.

A second situation requiring an exception to the 'but for' test may be where it is impossible to prove what a particular person in the causal chain would have done had the defendant not committed a negligent act or omission, thus breaking the 'but for' chain of causation. ${ }^{108}$

The facts of the second example - the facts of Walker Estate - also have their own rule for proof of factual causation: a sufficient-condition material contribution test that requires proof of factual causation on the balance of probability. ${ }^{109}$ As mentioned, the Walker Estate version of material contribution is limited to cases arising out of negligent screening of blood donors. ${ }^{110}$ The Resurfice material contribution doctrine is clearly not limited in that manner.

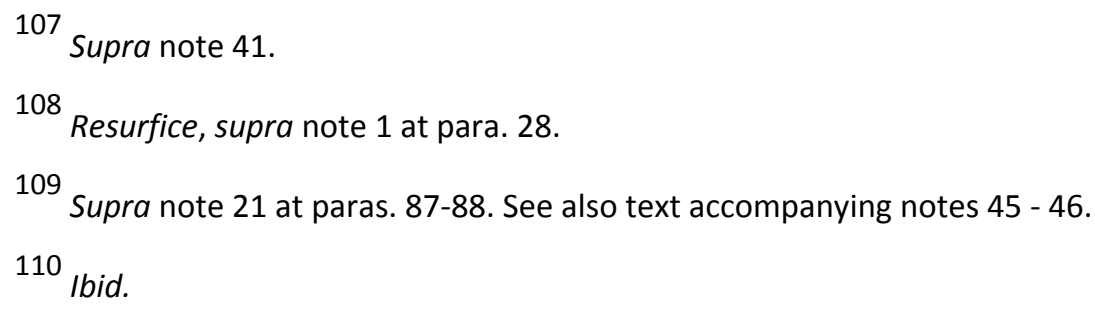


The alternative position is that Resurfice material contribution is nothing more than a clarified version of the Athey material contribution doctrine. Under this view, Resurfice should be understood to have finally explained the meaning of Athey's "unworkable", even if the Court did not state that that was what it was doing. Recall that Athey did not define "unworkable". It stated only that "[t]he 'but for' test is unworkable in some circumstances, so the courts have recognized that causation is established where the defendant's negligence 'materially contributed' to the occurrence of the injury". ${ }^{111}$ Resurfice, then, defined "unworkable" to mean instances where the but-for test cannot be validly used to prove or disprove factual causation, on the balance of probability, because of the current limits of scientific knowledge or analogous reasons.

There are a few Ontario Court of Appeal decisions which seem to claim that Resurfice material contribution is nothing more than a clarified version of Athey material contribution. This view is implicit in the statements that Resurfice did not alter the law of causation but only clarified it ${ }^{112}$ and that Resurfice material contribution is a test for factual causation. ${ }^{113}$ However, the Ontario appellate decisions did not explain these assertions about the meaning of Resurfice material contribution.

Barker v. Montfort is the leading Ontario decision case asserting the proposition that Resurfice "did not alter the state of the law on causation. Rather it confirmed that the basic test for determining causation remains the 'but for' test." ${ }^{114}$ The Barker v. Montfort dictum

\footnotetext{
${ }^{111}$ Athey, supra note 14 at para. 15 [citation omitted].

112 Barker v. Montfort Hospital, 2007 ONCA 282 at para. 51, 278 D.L.R. (4th) 215 [Barker]. See also Monks v. ING Ins. Co. of Canada, 2008 ONCA 269 at para. 86: "More recently, in Resurfice Corp. v. Hanke, [2007] 1 S.C.R. 333, the Supreme Court of Canada clarified the exceptions to the 'but for' causation test and the circumstances in which the material contribution test may be applied. I do not understand Resurfice to alter the basic causation principles that I have described." The "principles" that the court described, ibid. at para. 85, are a paraphrase of propositions in Athey. Monks is not a tort case. The issue was the interpretation of the causation provisions of motor vehicle accident benefits legislation. The Athey material contribution test governed that issue.

113

Frazer v. Haukioja, supra note 35, 2010 ONCA 249 at para. 41: "Factual causation can be established in two ways: the 'but for' test and the 'material contribution' test. Only one of these tests will apply in any given case. The differences between the two tests was recently clarified in Resurfice."

114 Supra note 112, 2007 ONCA 282 at para. 51 [internal quotation marks omitted].
} 
has not been quoted or referred to, since, in any reported decision. This silence could be evidence that some Ontario Court of Appeal judges believe that Resurfice did alter the law of causation. Better evidence is the fact that there are no Court of Appeal decisions since Resurfice referring to Mizzi v. Hopkins ${ }^{115}$ and Mizzi's explanation of the Athey material contribution test. In Mizzi, the Court of Appeal held that the Athey material contribution test, not the but-for test, is applicable to instances of what Resurfice would call "multi-cause injuries" where the injuries "are not susceptible to ... clear cut-division". ${ }^{116}$

The principles enunciated in Athey $v$. Leonati may be applied with relative ease when a plaintiff's injuries are [discrete], and clearly attributable to one or more independent tortious or non-tortious occurrences. Often, however, a plaintiff's injuries are not susceptible to such ready or clear-cut division. Rather, as noted by Major J. in Athey v. Leonati at p. 239, a plaintiff's injuries may emanate from "a myriad of other background events [or conditions] which were necessary preconditions" to the occurrence of the injuries in question. In such cases, it is frequently impossible to attribute a single cause to the plaintiff's injuries. For that reason, the Supreme Court has recognized that the traditional test for causation, the "but-for" test, is unworkable in some situations and, in those cases, should be replaced by the "material contribution" test, which is concerned with whether the defendant's negligence "materially contributed" to the occurrence of the plaintiff's injuries: Athey v. Leonati at p. 239 and Walker Estate v. York Finch General Hospital, [2001] 1 S.C.R. 647 at 679-80, per Major J. This case falls within the latter category of cases. ${ }^{117}$

The Walker Estate reference contains the passage that the Alberta Court of Appeal referred to in Resurfice. ${ }^{118}$ Mizzi's analysis is equivalent to the Alberta Court of Appeal's analysis of Athey material contribution in Resurfice. The fact that there was only one incident - the explosion - in Resurfice, so that the plaintiff's injury is a multi-cause injury only in the sense that the explosion had multiple causes, does not make the cases different.

Next, causation with a standard of proof less than the balance of probability is a radical change in Canadian tort law. "The elimination of causation as an element of negligence is a

\footnotetext{
115 Supra note 35. Mizzi has been cited for other reasons.

116 Ibid. at para. 31.

117 Ibid.

118 See supra at the text accompanying notes 23-24.
} 
radical step that goes against the fundamental principle." ${ }^{119}$ In principle, an argument can be made that that the Supreme Court did not intend anything so radical as creating a doctrine allowing liability in negligence without proof of factual causation on the balance of probability. The Court did not acknowledge it was creating a new doctrine. It claimed (or at least implied) it was not. ${ }^{120}$ The Court did not mention its own contrary decisions. ${ }^{121}$ We should assume that the judges of the Supreme Court are aware of the Court's jurisprudence. Without providing citations, the Court wrote that it was "assert[ing] general principles that emerge from the cases"; ${ }^{122}$ and that, "in special circumstances, the law has recognized exceptions to the basic "but for" test, and applied a "material contribution" test." 123 It had, but that was the Athey material contribution test. It was not the version of a material contribution test the Court was about to describe.

Paul Perrell ${ }^{124}$ has analyzed the Supreme Court's jurisprudence governing the manner in which that Court will change established common law. "In a series of cases, the justices of the Supreme Court of Canada ... decided ... that: 'major revisions of the law are best left to the legislature' and ... the judiciary should confine itself to those incremental changes which are necessary to keep the common law in step with the dynamic and evolving fabric of our society'."125 It cannot be argued, reasonably, that Resurfice material contribution is only an

119

Mooney, supra note 93 at para. 157. See also Barker v. Corus, supra note 99 at para. 126: "For the first time in our legal history, [negligent] persons are made liable for damage even though they may not have caused it at all, simply because they have materially contributed to the risk of causing that damage."

${ }^{120}$ Resurfice, supra note 1 at paras. 23-24.

${ }^{121}$ Snell, supra note 88; Hollis v. Dow Corning Corp., [1954] 4 S.C.R. 634, 1995 CanLII 55 [Hollis]; Athey, supra note 14; Walker Estate, supra note 21; Laferrière v. Lawson, [1991] 1 S.C.R. 541 at 605, 78 D.L.R. (4th) 609, 1991 CanLII 87 [Laferrière]; St.-Jean v. Mercier, supra note 94; Arndt v. Smith, [1997] 2 S.C.R. 539, 1997 CanLII 360 [Arndt]; and, Stewart v. Pettie, [1995] 1 S.C.R. 131, 1995 CanLII 147. See also Cheifetz "Tales" supra note 42 at 218-20 and Brown, "Hegemony", supra note 69.

122 Resurfice, supra note 1 at para. 20.

123 Ibid. para. 24.

124 Now Justice Paul Perrell of the Ontario Superior Court of Justice.

125 Paul M. Perrell, "Changing the Common Law And Why The Supreme Court of Canada's Incremental Change Test Does Not Work" (2003) 26 Adv. Q. 345 at 346 [internal footnotes omitted]. The Supreme Court cases cited are 
"incremental change" and is not "a major revision of the law" if that doctrine permits plaintiffs to satisfy the causation requirements of some causes of action in negligence through a possibility less than a probability of factual causation. If this new doctrine was created, that occurred without any reference to the Supreme Court's case law setting out the principles governing this type of radical change in Canadian common law.

There is no consensus on the meaning of Resurfice material contribution in common law Canada's primary tort treatises. Klar, Tort Law, published in mid-2008, seems to assert that Resurfice material contribution is not a test for factual causation of injury. Klar states that Resurfice "arguably .... revived, and perhaps even extended, McGhee." ${ }^{126}$ The McGhee reference is the explanation of McGhee revived by the House of Lords in Fairchild: the negligent creation of risk explanation under which fault and a possibility less than probability of factual causation may be sufficient to satisfy the causation requirements of the cause of action. ${ }^{127}$ Linden, Canadian Tort Law, ${ }^{128}$ does nothing more than paraphrase the material contribution paragraphs in the Resurfice reasons. ${ }^{129}$

Fridman, The Law of Torts in Canada, ${ }^{130}$ expressly describes Resurfice material contribution as a test for factual causation on one occasion, seemingly viewing the doctrine as a restated

Watkins v. Olafson, [1989] 2 S.C.R. 750 at 584, 1989 CanLII 36, 61 D.L.R. (4th) 577 and R. v. Salituro, [1991] 3 S.C.R. 654 at 670, 1991 CanLII 17, 68 C.C.C. (3d) 289.

126 Supra note 25 at 447 . This position is maintained in the forthcoming 5 th edition of Klar, Tort Law.

127 Supra note 89 at paras. 21-23, 35, 44, 64-70, 126, 143, 150, 154-55 (from the speeches of 4 of the 5 Law Lords. The fifth held that McGhee was based on the fiction of a legal inference of factual causation: ibid. at paras. 108-09, 116.) This quotation from Fairchild, at para. 67, suffices: "I therefore regard McGhee as a powerful support for saying that when the five factors I have mentioned are present, the law should treat a material increase in risk as sufficient to satisfy the causal requirements for liability."

128 Supra note 44.

129 Mr. Justice Linden wrote, in Allen M. Linden, "The Triumphs and Trials of Tort Canadian Tort Law" (Calgary, Canadian Bar Association, August 14, 2007) at 21 that Resurfice "does not reflect [the Court's] best thinking on the issue [of causation] which needs fuller treatment in the near future." [Words in brackets added.]

130 Supra note 69. 
version of Athey material contribution. ${ }^{131}$ However, other portions of the chapter on factual causation imply otherwise. Fridman states that "there is some reason to think that Resurfice, by adopting what would appear to be the Fairchild exception to but-for causation, has introduced into Canadian negligence law Fairchild's material increase in risk of harm approach to factual causation in certain exceptional cases." ${ }^{132}$ In Barker v. Corus, ${ }^{133}$ a majority of the Appellate Committee of the House of Lords confirmed that the Fairchild exception to but-for causation - the United Kingdom analogue of Resurfice material contribution - does not result in a finding of factual causation. ${ }^{134}$ Fridman also states:

... [T] hings may have changed with the court's decision in Resurfice. ... Depending on how one reads the language ... it may be possible to construct an argument from the claim that [liability] will sometimes flow from a defendant's negligently imposing on a plaintiff a risk of harm to the conclusion that negligently reducing a plaintiff's chance of a positive outcome is itself a form of harm. ${ }^{135}$

This passage is part of the text's discussion of Fairchild and Barker v. Corus. In Barker v. Corus, the House of Lords held that the injury which is the compensable injury under the Fairchild exception is the risk the negligence creates of the occurrence of the injury, not the resulting injury itself. ${ }^{136}$

Osborne, The Law of Torts, ${ }^{137}$ does not take a position on whether Resurfice material contribution is a merely a clarification of Athey or is a new doctrine under which the causation requirements in negligence may be satisfied even though the plaintiff cannot establish factual causation on the balance of probability. In noting the ambiguity in the

131 Ibid. at 407-08, 416 proposition 5.

132 Ibid. at 413.

133 Supra note 99.

134 Ibid. at inter alia, paras. 17, 53, 104. It was probably a 3-2 majority. Lord Rodger seems to have not agreed: see paras. 70-71, 83-86. The fifth member of the Appellate Committee, Baroness Hale, likely agreed with Lord Rodger on this issue.

135 Fridman, The Law of Torts In Canada, supra note 69 at 416 . I have substituted "[liability]" for the text's "negligence".

136 Supra note 74 at, inter alia, paras. 35-39, 48 (again by 3-2 majority).

137 Philip Osborne, The Law of Torts, 3d ed. (Toronto: Irwin Law, 2007) [Osborne, The Law of Torts]. 
language of Resurfice, Osborne states that, while the Supreme Court "sought to clarify the nature and applicability of the material contribution test in Resurfice", 138

[i]t is unlikely that Hanke will settle the confusion surrounding cause-in-fact because while seeking to marginalize the material contribution test the Court defined it by using language that is both reminiscent of the views of Lord Wilberforce in McGhee, and capable of a very broad interpretation contrary to the Court's apparent intent. ${ }^{139}$

However, Osborne does not explain the Court's apparent intent. The text merely paraphrases the Resurfice material contribution passages. Osborne describes the Resurfice examples in the footnote accompanying the passage just quoted. "The Court gave only two narrow examples of where the Hanke test might apply. The first was the concept of alternative liability found in Cook v. Lewis ... and the second was illustrated by the facts of Walker where cause-in-fact depends on the unknowable decision of a third party." ${ }^{140}$

Another consequence of Resurfice is that, in practice, the Athey version of material contribution is defunct. With very few exceptions, the reported cases since Resurfice show that no version of the Athey material contribution test is now formally used for proof of factual causation on the balance of probability in a negligence action, regardless of the continued use of the phrase "caused or contributed" by some lawyers and judges. ${ }^{141}$ This has occurred even though there is nothing in Resurfice that can be understood to be a reference to the Athey version of a material contribution test, as it was understood in the Canadian jurisprudence prior to Resurfice, outside of the two paragraphs in which the

138 Ibid. at 57 (italics in original).

139

lbid. at 58 (italics in original).

140

Ibid. at 58 n. 69.

141

Where it has been explicitly used, the usage was declared wrong on appeal, if the case was appealed and the findings of fact could not be justified on a but-for basis: see infra at notes 146 and 540 . If one were to ask those who still use "caused or contributed" what they understand the difference to be in the two terms, I suspect the answers would be versions of the explanation that "cause" refers a situation where the negligence is the "only" cause and "contributed" the example where there are multiple necessary causes. See, for example, B.( $M$.). $v$. 2014052 Ontario Ltd. (2012), 109 O.R. (3d) 351 at para. 29, 2012 ONCA 135 [B.(M.) v. 2014052]: "Successive and cumulative injury cases, including those involving pre-existing conditions, can also satisfactorily meet the 'but for' test. This is because a defendant's negligence need only be 'a' cause, not 'the' cause of the injury". [Internal quotation marks and brackets omitted.] 
Supreme Court discussed the reasons of the Alberta Court of Appeal and held that the Athey material contribution test was not applicable because the but-for test was. ${ }^{142}$

In practice, the result is that but-for doctrine has absorbed the pre-Resurfice meaning of a factual causation under Athey material contribution, whatever that meaning actually was. ${ }^{143}$ There are British Columbia Court of Appeal decisions explicitly stating that "materially contributing" as used in Athey means "but-for". ${ }^{144}$ In British Columbia, at least, the law on factual causation has become what Linden, Canadian Tort Law, asserts it always should have been.

This seemingly innocent phrase, material contribution, unleashed a debate in which some lawyers and judges mistakenly thought that it was meant to be a new, less rigourous test for determining causation that would replace the more rigid 'but-for' test. This is wrong. The language, 'material contribution', was merely meant to be another way of describing the 'but-for' test, when more than one causal factor was involved in an event ... ${ }^{145}$

This statement is a concession that a decade's worth of Canadian tort jurisprudence on the meaning of factual cause has no doctrinal value, except in the negative sense of highlighting a wrong analysis. Not surprisingly, neither Linden, Canadian Tort Law, nor the British Columbia Court of Appeal, suggests that the results of the cases which applied the Athey material contribution test in the plaintiff's favour were wrong.

142 Resurfice, supra note 1 at. paras. 18-19.

143 See David Cheifetz, "The Snell Inference And Material Contribution: Defining The Indefinable And Hunting The Causative Snark - A Not Excessively Subtle and Theoretical Examination of Proof of Factual Causation in Canadian Tort Law" (2005), 30 Adv. Q. 1 ["Snell Inference"] at 56-103 for a detailed examination of Athey material contribution. See also Klar, Tort Law, supra note 17 at 437-41. The parameters of Athey material contribution were contentious, despite its regular use. Ken Cooper-Stephenson wrote: "there is nowhere ... any sensible description of what is meant by [Athey] material contribution": Ken Cooper-Stephenson, "Justice in Saskatchewan Robes: The Bayda Tort Legacy" (2007), 70 Sask. L. Rev. 269 at 303 [word in brackets added, internal quotation marks omitted].

144 For example: Farrant v. Latkin, 2011 BCCA 336 at paras. 9-11, reversing 2008 BCSC 234; Chambers v. Goertz, 2009 BCCA 358; and Sam v. Wilson, 2007 BCCA 622 at para. 109, 287 D.L.R. (4th) 608 [Sam]. See, however, the majority reasons in Nattrass v. Weber, 2010 ABCA 64, 316 D.L.R. (4th) 666, reversing 2008 ABQB 259, leave to appeal refused, 2010 CanLII 52689 (S.C.C.).

145

Linden, Canadian Tort Law, supra note 44 at 124. 
So far, Resurfice has made no difference to the result of reported cases that have advanced beyond the trial level. No case in which a trial judge openly applied his or her understanding of Resurfice material contribution, or any other version of material contribution, as the basis for holding that the plaintiff had satisfied the causation requirements of the cause of action has survived appeal, unless the appellate court concluded that the trial judge's findings of fact, on the evidence, amounted to but-for findings. Cases in which the trial judge expressly purported to apply Athey material contribution, as the basis for holding that factual causation was sufficiently proven, have been reversed and dismissed if the appellate court was not able to find that the trial judge's findings and conclusions were correct on a but-for basis. ${ }^{146}$ There has not yet been a reported case where the action was dismissed because the court held that the but-for test governed, the plaintiff failed to satisfy the but-for test, and the trial judge or any appellate judge said that he or she would have held that factual causation was established under some version of a pre-Resurfice material contribution test but for Resurfice.

\footnotetext{
146 A number of these cases were not appealed. Fullowka v. Pinkerton's of Canada Ltd., [2010] 1 S.C.R. 132 at paras. 93-95 , 2010 SCC 5, aff'g 2008 NWTCA 4, [2008] 7 W.W.R., rev'g 2004 NWTSC 66, [2005] 5 W.W.R. 420 [Fullowka] is an example of case tried before Resurfice where the trial judge used Athey material contribution not but-for. That was held to be an error by both the Northwest Territories Court of Appeal and the Supreme Court. In Moore v. Wienecke, 2008 ONCA 162, 90 O.R. (3d) 463, aff'g 2006 CanLII 1195 (Ont. S. C J.) the trial judge's preResurfice findings of factual causation based on Athey material contribution were upheld by the Ontario Court of Appeal on the basis that the findings amounted to but-for findings. In Donley Investments Limited v. Canril Corporation, 2011 ONCA 625 [Donley Investments] the trial judge referred only to Athey material contribution and applied that doctrine in finding that the plaintiff had proved factual causation. The Ontario Court of Appeal set aside the decision for that reason, and other errors of law, and ordered a new trial. In both Bohun v. Segal, 2008 BCCA 23, 289 D.L.R. (4th) 614 and Clements (Litigation Guardian of) v. Clements, 2011 BCCA 581, rev'g 2009 BCSC 112; leave to appeal granted 2011 CanLII 36004 (S.C.C.) (appeal argued February 17, 2012; judgment reserved) [Clements] the plaintiffs succeeded at trial by establishing causation on the basis of the judge's view of the meaning of Resurfice material contribution. The trial judges held that the plaintiff had failed to satisfy the but-for test. The cases were dismissed on appeal. In Bohun, the British Columbia Court of Appeal held that the trial judge had misunderstood the evidence and the defendant had disproved factual causation on the balance of probability. In Clements, the Court of Appeal held that once the trial judge had found that the plaintiff had not proved factual causation on the balance of probability, the action should have been dismissed as there was no basis for applying Resurfice material contribution. Clements is discussed in more detail later in this chapter.
} 


\subsection{Causation Without Probability}

\subsubsection{Introduction and Overview}

This section reviews some of the changes in the content of Canadian causation jurisprudence as a result of the Resurfice. Resurfice provides direction on both but-for test and its version of a material contribution test. The focus of this paper is Resurfice material contribution. The but-for test is discussed only to the extent needed to explain Resurfice material contribution.

Resurfice created a new doctrine by which, in some circumstances, a plaintiff will be able to satisfy the causation requirements of a cause of action in negligence without establishing factual causation on the balance of probability. ${ }^{147}$ However, as the justification for the doctrine is "notions of fairness and justice", there is no reason, in principle, to exclude the doctrine from other torts, or other causes of action, where factual causation has to be established on the balance of probability. There is nothing explicit in Resurfice on the relationship between the Resurfice version of a material contribution test and the doctrine falling under the interchangeable labels of proximate cause or remoteness. Remoteness is a defence, limiting the extent of liability for wrongful conduct found to be an actionable cause. Remoteness doctrine asks whether liability ought to be imposed on a defendant for wrongful conduct found to be an actionable cause of compensable injury. ${ }^{148}$ The policy question is "where to draw the line". ${ }^{149}$ The remoteness or proximate cause issue is implicit in the Court's statement that "notions of fairness and justice" 150 underlie and limit the use of the Resurfice material contribution test.

\footnotetext{
147 The alternative argument is that Resurfice material contribution is nothing more than a restated version of the Athey material contribution doctrine. The merits of these two interpretations of Resurfice are discussed in Chapter 3.1. commencing with the text accompanying note 80 through the balance of the chapter. See also Cheifetz, "Tales", supra note 5 at 206-211. 
Resurfice sets out the explicit requirements of its version of material contribution in one paragraph.

First, it must be impossible for the plaintiff to prove that the defendant's negligence caused the plaintiff's injury using the "but for" test. The impossibility must be due to factors that are outside of the plaintiff's control; for example, current limits of scientific knowledge. Second, it must be clear that the defendant breached a duty of care owed to the plaintiff, thereby exposing the plaintiff to an unreasonable risk of injury, and the plaintiff must have suffered that form of injury. In other words, the plaintiff's injury must fall within the ambit of the risk created by the defendant's breach. In those exceptional cases where these two requirements are satisfied, liability may be imposed, even though the "but for" test is not satisfied, because it would offend basic notions of fairness and justice to deny liability by applying a "but for" approach. ${ }^{151}$

The requirements of the Resurfice material contribution test may be summarized this way. The test may be applied only where (a) it is impossible, for qualifying reasons, to validly apply the but-for test to determine, on the balance of probability, whether factual causation exists or does not exist; (b) the compensable injury that the plaintiff sustained is within the ambit of the risk upon which the defendant's duty to the plaintiff was based; and (c) it must "offend basic notions of fairness and justice" to dismiss the action solely on the basis that the plaintiff was unable to satisfy the requirements of the but-for test. ${ }^{152}$ Therefore, the mere fact the plaintiff failed to establish factual causation on the balance of probability is not sufficient to trigger the doctrine. ${ }^{153}$

It is implicit in Resurfice that the plaintiff will still have to establish, on the balance of probability, that the negligence could be a cause of the injury the plaintiff. The burden of

\footnotetext{
151 Resurfice, supra note 1, para 25. In Fullowka, supra note 146 at para. 95, the Court summarized para. 25 of Resurfice in way that does not mean what para. 25 asserts as written. Fullowka did not explain why the summary differs from the text of Resurfice. The better view is that the Court did not intent to alter anything it said in Resurfice.

152 Some of these are propositions based on my view of the better reading of the text, not (yet) the text as explained by subsequent case law.

153 Fullowka, supra note 146; Clements, supra note 146.
} 
proof remains the balance of probability for all past events that the plaintiff will have to establish to satisfy the causation requirements. ${ }^{154}$

The Supreme Court has mentioned Resurfice's material contribution dicta only once since Resurfice: in Fullowka. ${ }^{155}$ In September 1992, a number of miners were killed in an explosion in a mine. The incident occurred during a strike. The cause was a bomb. Another miner suffered psychological injury when he saw the bodies. The plaintiffs sued the mine owner, the security company employed by the owner, the local and national unions for the mine workers and the territorial government. The trial took place in 2004. The plaintiffs succeeded at trial. The trial judge applied the Athey material contribution test to find that the negligent conduct of certain of the defendants, together with the conduct of the bomber, was a cause of the plaintiffs' injuries. The appeal was heard in 2007, after Resurfice. The Northwest Territories Court of Appeal dismissed the action. That court held there was no duty and, in any event, no breach of duty. The court held that the trial judge erred in applying the Athey material contribution test rather than the but-for test. ${ }^{156}$ The court held the facts did not

\footnotetext{
154

F.H. v. McDougall, [2008] 3 S.C.R. 41, 2008 SCC 53 [McDougall], holds that the common law standard of proof for all issues in civil matters is the balance of probability. The statement must be understood to have been intended to apply to past events. It must be accepted that the Court did not intend to suggest this proposition applied to proof of post-trial events and the assessment of post-trial damages. Athey, supra note 14 at para. 27, states: "Hypothetical events (such as how the plaintiff's life would have proceeded without the tortious injury) or future events need not be proven on a balance of probabilities. Instead, they are simply given weight according to their relative likelihood ... A future or hypothetical possibility will be taken into consideration as long as it is a real and substantial possibility and not mere speculation."

155

Supra note 146. The Court dealt briefly with but-for causation in Hill v. Hamilton-Wentworth Regional Police Services Board., [2007] 3 S.C.R. 129, 2007 SCC 41. Resurfice and material contribution are not mentioned. The majority reasons contain statements about factual causation and the but-for test that could be seen to conflict with Resurfice if taken at face value. The statements should not be understood to create or to have been intended to create conflict with Resurfice or prior causation case law. Causation was a minor issue in Hill. It is unlikely the Court intended to say anything about causation jurisprudence that conflicted with Resurfice or otherwise said something new about causation law.

156

The Court of Appeal's discussion of Resurfice material contribution is cursory and not helpful. See infra at the text accompanying note 184 .
} 
establish that the conduct of the defendants (other than the bomber) was a probable cause. The Supreme Court affirmed the dismissal on the basis that there was duty but no breach. ${ }^{157}$

The Supreme Court's discussion of the causation issues is brief. ${ }^{158}$ The Court agreed that the but-for test was applicable rather than a material contribution test and the plaintiffs had not established that the negligence of any of the defendants was a cause. The Court agreed the trial judge had applied Athey material contribution and that the trial judge should have used the but-for test. ${ }^{159}$ The Court then referred briefly to Resurfice.

The appellants submit in the alternative that this case falls into the class of exceptional situations discussed in Hanke in which the test for causation should be relaxed to the "material contribution" standard. I cannot accept this submission. As Hanke made clear, the sorts of special situations for which the material contribution test is reserved generally have two characteristics. First, it is impossible for the plaintiff to prove that the defendant's negligence caused the injury under the "but for" test, and second, it is clear that the defendant breached a duty of care owed to the plaintiff and thereby exposed the plaintiff to an unreasonable risk of injury of the type which the plaintiff ultimately suffered: Hanke, at para. 25. This case has neither of these characteristics. It was not impossible to prove causation to the "but for" standard. The appellants' submissions in effect demonstrate this: their primary position is that they did so and the trial judge found that they had. Moreover, there was no clear breach of a duty: for the reasons I have given, I would hold that neither Pinkerton's nor the government breached its duty of care towards the murdered workers. It follows that the "but for" standard should have been, but was not applied by the trial judge. ${ }^{160}$

Subject to one caveat, the better view of Fullowka is that it does not provide any explanation of Resurfice material contribution. The better view is also that the Court did not intend to alter anything it had said about the impossibility requirement in Resurfice, even though Fullowka's summary of that requirement omits the "current limits of scientific knowledge" proviso.

\footnotetext{
157 Fullowka, supra note 146, [2010] 1 S.C. R. 132 at paras 1-10, 13-14, 92-96; 2008 NWTCA 4 at paras. 182-206; 2004 NWTSC 66 at paras. 609-14, 897-90. 
Fullowka should not be understood to hold the mere fact that plaintiff argues that the facts satisfy the but-for test requires the conclusion that it is possible to validly use the but-for test to prove or disprove factual causation. It is the reasons why the but-for test fails in a particular case, and not the manner in which the plaintiff, or the defendant, attempt to use (or misuse) it, that will determine if the Resurfice material contribution test is applicable if the but-for test is not. Similarly, the statements in Frazer v. Haukioja ${ }^{161}$ should be understood to mean only that was not necessary for the trial judge to consider whether the Resurfice material contribution could be applied once the trial judge found that the plaintiff had established factual causation on the balance of probability. ${ }^{162}$ Any rule that makes the availability of Resurfice material contribution depend on a plaintiff's election not to attempt to prove factual causation on the balance of probability offends basic principles of justice.

The caveat is what Fullowka meant by "no clear breach of a duty", ${ }^{163}$ assuming the Court's intention was to signal that the concept of a clear beach of duty will be relevant to the determination of whether Resurfice material contribution is applicable. If that statement was intended to refer to any aspect of the Resurfice material contribution doctrine, it could only be the ambit of risk requirement.

[I]t must be clear that the defendant breached a duty of care owed to the plaintiff, thereby exposing the plaintiff to an unreasonable risk of injury, and the plaintiff must have suffered that form of injury. In other words, the plaintiff's injury must fall within the ambit of the risk created by the defendant's breach. ${ }^{164}$

161 Supra note 28.

162 Ibid., 2010 ONCA 249 at paras. 29 and 42. The explanation for the comments in Frazer is the panel's belief that Resurfice material contribution is another method of establishing factual causation. See Frazer at para. 41 . The trial judge realized it is not. The premise for his alternative Resurfice material contribution analysis is the assumption that he had erred in finding that the plaintiff had established factual causation on the balance of probability under but-for. See supra note 28, 2008 CanLII 42207 at para. 217.

163

Fullowka, supra note 146, [2010] 1 S.C.R. 132 at para. 95 [emphasis added].

164 Supra note 1 at para. 25 [emphasis added]. 
It is likely that Fullowka's use of "clear" was intended to echo Resurfice's in the definition of the ambit of risk requirement. ${ }^{165}$

"Clear breach of duty" is an odd statement. Was it the Supreme Court's intent to signal that basic notions of fairness and justice towards defendants require the courts to be more circumspect in applying a doctrine of causation premised on a possibility less than a probability of factual causation - since that entails the concession that there is a significant possibility (even if less than a probability) that the causation decision is wrong - in cases where the breach of duty decision is a close call ${ }^{166}$ There is either a breach of the duty of care or there is not. The facts upon which the decision is made as to whether there was a breach of duty might or might not be contentious. If the facts are clear enough, the judge or jury makes the decision required by those facts. The plaintiff has failed to establish a breach of duty if the facts are not clear enough to allow a decision to be made validly on the balance of probability. ${ }^{167}$ What could "clear" mean in a case where there has been a finding of breach of duty? That finding, since is based on past facts, is treated as a conclusive finding that the breach occurred. "Past events must be proven, and once proven they are treated as certainties." 168 It is not clear, then, what "clear" adds to the concept of breach of duty.

Does it matter if the duty that was breached was an established duty, rather than a novel duty declared to exist in the judgment holding the defendant liable? Tort law, as private law, speaks retrospectively. ${ }^{169}$ Perhaps there are cases in which it can be said, reasonably, that a defendant ought to have foreseen the law might change. But that will not always be so. Did

\footnotetext{
165 Resurfice, supra note 1 at para 25: “... it must be clear that the defendant breached a duty of care owed to the plaintiff ...".

166 This argument becomes stronger if the extent of liability under Resurfice material contribution is solidary (joint and several) rather than proportional (several). See infra at note 502 and accompanying text.

167 McDougall, supra note 154.

168 Athey, supra note 14 at para. 28;

169 Canada (Attorney General) v. Hislop, [2007] 1 S.C.R. 429, 2007 SCC 10; British Columbia v. Imperial Tobacco Canada Ltd., [2005] 2 S.C.R. 473, 2005 SCC 49.
} 
the Court intend to signal that there is a hierarchy of duties of care such that only some are important enough that a breach of that duty is capable of creating the exceptional circumstances required by Resurfice? The Supreme Court should have been clearer if it meant that, in instances where breach of duty is found, questions relating to the nature of the duty of care in issue, and how certain the conclusions are on those issues, will play some part in the decision as to whether Resurfice material contribution is applicable. If these issues could be any part of the Resurfice material contribution doctrine, it seems they should be a component of the fairness and justice control, assuming there is such a control. ${ }^{170}$

British Columbia Court of Appeal decisions are clear that Resurfice material contribution is a new development. The leading decisions are Farrant v. Latkin; ${ }^{171}$ Clements v. Clements; ${ }^{172}$ Chambers v. Goertz; ${ }^{173}$ Sam v. Wilson; ${ }^{174}$ Bohun v. Segal; ${ }^{175}$ B.S.A. Investors Ltd. v. DSB; ${ }^{176}$ Seatle v. Purvis; ${ }^{177}$ and, Jackson v. Kelowna General Hospital. ${ }^{178}$ The Alberta Court of Appeal decision in Nattrass $v$. Weber ${ }^{179}$ seems to support that conclusion. There are four Ontario Court of Appeal decisions which, in one way or the other, suggest that Resurfice did nothing more than "clarify" causation law: B.(M.) v. 2014052 Ontario Ltd.; ${ }^{180}$ Frazer v. Haukioja; ${ }^{181}$

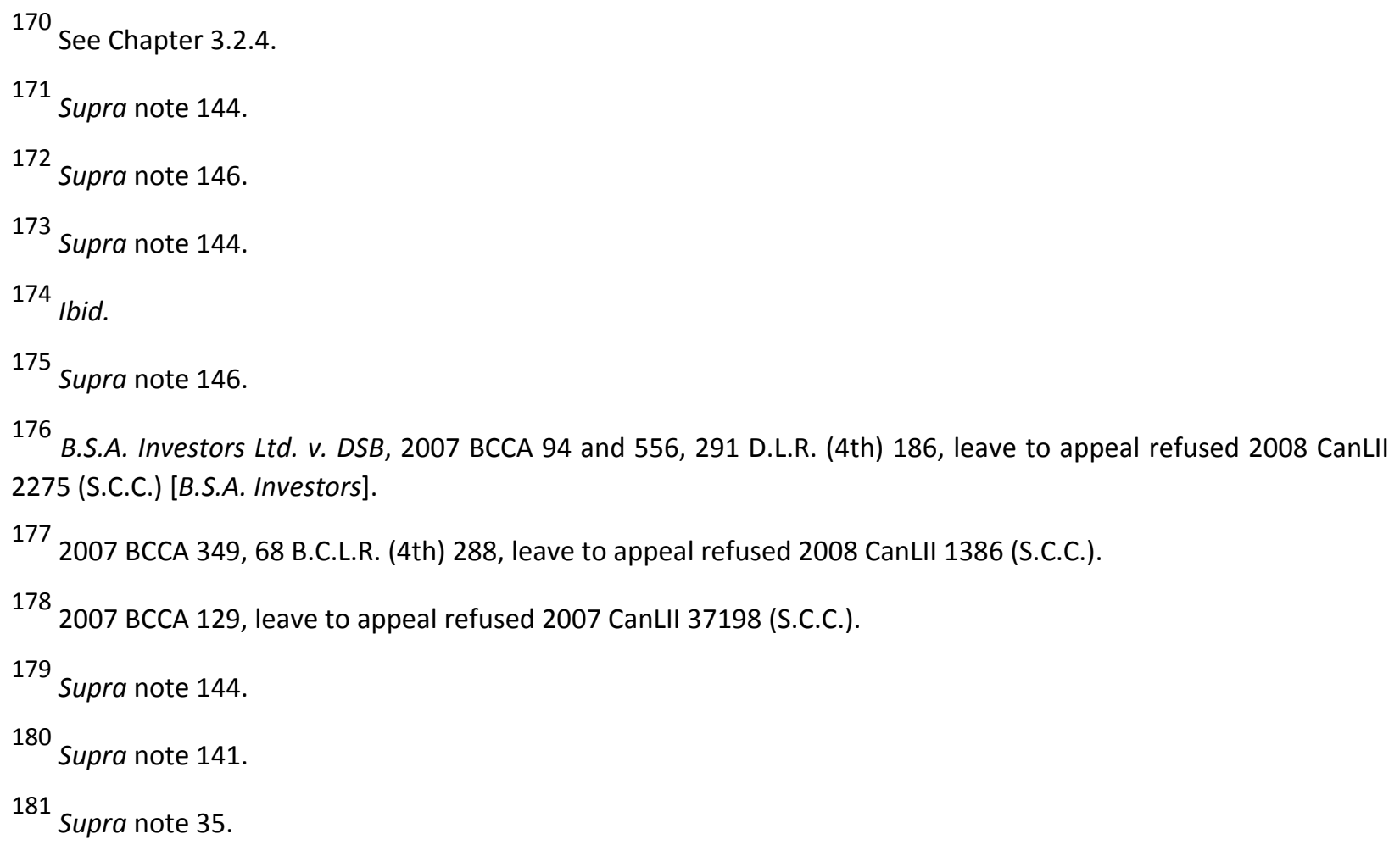


Barker v. Montfort Hospital; ${ }^{182}$ and Monks v. ING Ins. Co. of Canada. ${ }^{183}$ The Ontario Court of Appeal has avoided the issue in all other cases where Resurfice has been mentioned. The Courts of Appeal of Alberta, British Columbia, and Ontario have not acknowledged the existence of contrary views on the meaning of Resurfice in other appellate courts. The discussion of material contribution doctrine in the reasons of the Northwest Territories Court of Appeal in Fullowka is cursory. The better interpretation of that decision is that judges thought that Resurfice material contribution is a restated version of the Athey material contribution test and, as such, a test for the existence of factual causation. ${ }^{184}$ The Supreme Court, in its Fullowka reasons, did not comment on anything the Court of Appeal said about material contribution doctrine, other than agreeing that test did not apply because the but-for test applied. ${ }^{185}$ There is nothing relevant from the courts of the other common law jurisdictions, the courts of Quebec, or the Federal courts.

In Sam v. Wilson, the majority of a panel of the British Columbia Court of Appeal provided an explanation of Resurfice material contribution which seems to be the meaning most consistent with the text of Resurfice.

As McLachlin C.J.C. explained in Resurfice Corp. v. Hanke, at paras. 24-29, the 'material contribution test' applies as an exception to the 'but for' test of causation when it is impossible for the plaintiff to prove that the defendant's negligent conduct caused the plaintiff's injury using the 'but for' test, where it is clear that the defendant breached a duty of care owed the plaintiff thereby exposing the plaintiff to an unreasonable risk of injury, and where the plaintiff's injury falls within the ambit of the risk. In my reasons for judgment in B.M. v. British Columbia (Attorney General), 2004 BCCA 402, 31 B.C.L.R. (4th) 61 at paras. 153-166, I traced the development of this principle from its genesis in McGhee v. National Coal Board, [1972] 3 All E.R. 1008 (H.L.) through to Fairchild v. Glenhaven Funeral Services Ltd., [2002] UKHL 22, [2002] 3 All E.R. 305 and noted that it is not a test of causation at all: rather, it is a rule of law based on policy. .... ${ }^{186}$

\footnotetext{
182 Supra note 112.
}

183 Ibid.

184 See Fullowka, supra note 146, 2008 NWTCA 4 at para. 195.

185 See supra text accompanying notes $155-164$ for the discussion of Fullowka.

186 Supra note 144 at para. 109. The plaintiff succeeded at trial. The trial occurred before Resurfice. The appeal was argued on the basis that the but-for test was the applicable test: see para. 34 . The majority allowed the 
In Chambers v. Goetz, ${ }^{187}$ and recently in Clements, ${ }^{188}$ the British Columbia Court of Appeal reiterated the position that the Resurfice material contribution doctrine is not a test for determining factual causation: ${ }^{189}$ "the use of the [Resurfice] material-contribution test leads to the finding of a legal, as opposed to a factual, connection between a defendant's negligence and the harm suffered by a plaintiff." 190

As of writing, Clements is the last significant provincial appellate attempt to explain the meaning of Resurfice material contribution. ${ }^{191}$ The plaintiff, riding pillion, was seriously injured in a single-vehicle motorcycle accident. The motorcycle's rear tire was punctured, likely by a nail. The tire deflated rapidly. The deflation caused the driver to lose control and the bike to weave. The driver was able to slow the bike down but not enough that he and his passenger could dismount safely. The bike capsized at a speed of about 37 kilometres per hour. The trial judge held that the defendant was not negligent in losing control. The defendant's negligence was in driving too quickly for the conditions. The conditions included the wet road and that the motorcycle was overloaded. ${ }^{192}$ The factual causation question was whether that negligence was a cause of the driver being unable to regain control. The trial

defendant's appeal and dismissed the action. The dissenting judge would have dismissed the appeal. The dissenting judge did not comment on the majority's explanation of Resurfice material contribution.

187 Supra note 144 at paras. 15-18 ( 2 of 3 judges; the third declined to express an opinion on the issue). 188 Supra note 146 at paras. $45-46$.

189 Ibid. at para. 45.

190 Ibid. at para. 46.

191

For case comments on Clements, see: Russell Brown and David Cheifetz, "The Bounds Of 'Common Sense' Inferences Of Causation: Clements v. Clements and the Art of Motorcycle Factum Maintenance" (2012) 40 Adv. Q. 34 [Brown and Cheifetz, "Inferences of Causation"]; Erik S. Knutsen, "Causal Draws and Causal Inferences: A Solution to Clements v. Clements (And Other Causation Cases) (2011), 39 Adv. Q. 241 at 241 [Knutsen, "Causal Draws"], and Lynda M. Collins "Causation, contribution and Clements: Revisiting the material contribution test in Canadian tort law" (2011), 19 Tort L. Rev. 86 [Collins, Causation, contribution and Clements]. The process of inference drawing is usefully reviewed in Russell Brown, "Known Unknowns in Cause-in-Fact" (2011) 39 Adv. Q. 37 [Brown, "Known Unknowns"]; Russell Brown, "The Possibility of 'Inference Causation': Inferring Cause-In-Fact And The Nature Of Legal Fact-Finding" (2010) 55 McGill L. J. 1 [Brown, "Inference Causation"]; and Russell Brown, "Inferring Cause-in-Fact and the Search for Legal 'Truth'”, in Richard Goldberg, ed., Perspectives on Causation (Oxford: Hart Publishing, 2011) 93.

192

Clements, supra note 146, 1002 BCSC 112 at paras. 58, 61-62. 
judge held that the evidence did not permit him to make that conclusion, on the balance of probability, applying the but-for test. The evidence included the testimony of an expert called by the defendant. Nonetheless, the trial judge concluded that common sense supported the conclusion that there was a causal connection between the negligence and the driver's inability to regain control, and the facts justified the application of the Resurfice material contribution test. ${ }^{193}$

The British Columbia Court of Appeal held that the but-for test applied, agreed that the facts did not satisfy that test, and dismissed the action. ${ }^{194}$ The court held that qualifying impossibility under Resurfice material contribution is not established by the mere fact that the current limits of scientific knowledge do not permit a plaintiff to adduce expert evidence that the defendant's negligence was a probable cause. ${ }^{195}$ The Court of Appeal held that the plaintiff's action should be dismissed because it was merely "a case like many others in which, given the current state of knowledge, it is not possible to prove whether the negligent actions of a defendant caused harm". ${ }^{196}$ There was no valid reason why the plaintiff should be allowed to succeed where other similarly situated plaintiffs would not. ${ }^{197}$ Clements contains a number of propositions on the meaning of Resurfice material contribution.

\section{The material contribution doctrine}

193 Ibid. at paras. 64-67. The trial judge held that the defendant's expert evidence established that the causal connection could not be proved or disproved on the balance of probability (para. 63). It is probable that the trial judge misunderstood the defence evidence. That evidence, as noted by the Court of Appeal (2010 BCCA 581 at para. 23), was that the bike would have capsized even if the bike's speed had been the lower speed which the judge found was the proper speed for the conditions. The trial judge's misunderstanding of the evidence is discussed in more detail in Brown and Cheifetz, "Inferences of Causation", supra note 191. The trial judge seems to have thought that Resurfice material contribution is a combination of the Athey and Resurfice versions. See 2009 BCSC 112 at para. 67.

194

Clements, supra note 146, 2010 BCCA 581 at paras. 64-65.

195

Ibid. at paras. 59, 63-64.

196

Ibid. at para. 64.

197 Ibid. 
discussed in Resurfice Corp. is not a test for determining factual causation. It does not provide a framework for determining whether a plaintiff has proven on a balance of probabilities that a defendant's negligence has in fact caused harm. Rather, it provides a basis for finding legal causation when there is a possibility that the defendant's negligent actions could have been a factual cause. ${ }^{198}$

2. " $[T]$ he material contribution test should be reserved for rare cases involving logical impossibilities" in the proof or disproof of factual causation on the balance of probability. ${ }^{199}$

3. The "current limits of scientific knowledge" proviso does not "mean that the material contribution test is appropriate in any case where the science involved is difficult, complex, or 'just not there yet'." 200

4. "That forensic science is not always able to provide an answer to a causation question is not a reason for doing away with causation as an essential element of a plaintiff's case." ${ }^{201}$

5. There is an "over-arching policy that the material-contribution test is available only when a denial of liability under the but-for test would offend basic notions of fairness and justice." 202

Propositions 2-5, taken together, have two different meanings. It is not clear whether the Clements panel realized this. The first is that Clements intended to say only that the "basic notions of fairness and justice" are part of the impossibility requirement. Under this interpretation, the inquiry into whether the impossibility requirement has been satisfied

198 Ibid. at para. 45 [emphasis in original] citing Chambers v. Goertz, supra note 144, and Sam v. Wilson, supra note 144. See also Clements, ibid. at para. 46.

199 Ibid. at para. 58.

200 Ibid. at para. 58, quoting Erik S. Knutsen, “Clarifying Causation” (2011) 33 Dal. L. J. 143 at 171 [Knutsen, "Clarifying"]. See Chapter 3.2.2.1. for the discussion of the meaning of the "current limits of scientific knowledge" proviso.

201 Ibid. at para. 59.

202 Ibid. at para. 63. See Chapter 3.2.4. 
requires the court to decide: (1) whether the reason the plaintiff has failed to establish causation on the balance of probability is due to "current limits of scientific knowledge"; and, (2) if the answer to that question is "yes" then do "basic notions of fairness and justice" require the court to conclude that the impossibility requirement has been satisfied? Under this interpretation, the impossibility requirement is not satisfied if the answer to the second inquiry is "no".

The alternative meaning is that the fairness and justice issue is not part of the impossibility inquiry and requirement but a separate requirement which must be satisfied. Under this interpretation, the court would have to decide if the fairness and justice requirement has been satisfied even if both the impossibility and ambit of risk requirements are satisfied and could decide that it has not been. None of the propositions are more consistent with the first interpretation than the second. The language of the fifth proposition is more consistent with the second interpretation.

It will not matter, to the particular plaintiff, where the fairness and justice requirement appears in the analysis, if there is such a requirement. It will have to be met. The Resurfice material contribution doctrine will not apply if there is a fairness and justice requirement that has not been satisfied. If there is a fairness and justice requirement at all, it must be applicable to the ambit of risk requirement too. The second interpretation seems to be the better conclusion at least because it limits the number of times the fairness and justice analysis has to be done and because that analysis necessarily takes into account system of justice considerations, not just the interests of the parties to the action. ${ }^{203}$

In Nattrass v. Weber, the majority of a panel of the Alberta Court of Appeal described Resurfice material contribution as "an exception where it is impossible for the plaintiff to prove causation to the 'but for' standard" 204 and as "an exceptional alternative standard of

\footnotetext{
203 The issue of the fairness and justice requirement is considered in more detail in the sections in Chapter 3 for each of the impossibility, ambit of risk, and fairness and justice requirements .

204 Supra note 144 at para. 47.
} 
proof that can sometimes be used to prove causation". ${ }^{205}$ The court did not write "factual causation". ${ }^{206}$ If there is a clue here, it is in the majority's use of "causation" rather than "factual causation". The better conclusion is that if the majority had meant "factual causation" they would have written "factual causation". If this is correct, the use of "causation" is a signal that the majority agreed that Resurfice material contribution is not a method of establishing factual causation. Instead, it is a method by which the plaintiff may be able to satisfy the causation requirement of the cause of action even though factual causation cannot be proved, or disproved, on the balance of probability. ${ }^{207}$

The leading Ontario cases are the Court of Appeal decisions in Barker v. Montfort, ${ }^{208}$ Frazer v. Haukioja ${ }^{209}$ and B.(M.). v. 2014052. ${ }^{210}$ Barker v. Montfort asserts that Resurfice "did not

205

Ibid. The complete text of the paragraph is: "In Resurfice the Supreme Court of Canada confirmed that the "but for' test is the presumptive legal test, and confirmed an exception where it is impossible for the plaintiff to prove causation to the 'but for' standard. Unfortunately that exceptional rule is also called 'materially contributes', leading to potential confusion. In Athey, de minimis or 'non-material contribution' is an exception to liability where several causes contribute to the damage. It could be described as a type of de minimis defence or limit on liability. In Resurfice, 'material contribution' is an exceptional alternative standard of proof that can sometimes be used to prove causation." The difference between the comments on Athey and the last sentence on Resurfice is another reason for concluding that "causation" does not mean "factual causation".

206

The discussion of factual causation jurisprudence occurs in Nattrass, ibid., at paras. $43-46$ and the portion of para. 47 preceding the last sentence.

207

On the other hand, Slatter J.A., who was part of the Nattrass majority, was also on the panel of the Northwest Territories Court of Appeal that heard Fullowka. The latter reasons imply that Resurfice material contribution was seen as a method of establishing factual causation: see supra note 146. The dissent in Nattrass, supra note 144, does not contain anything relevant to the issues even though the dissenting judge held that the trial judge was "warranted in applying the 'material contribution' test". The dissenting judge would have affirmed the trial judgment against all three defendants. She held that, even assuming the trial judge had failed to properly apply the but-for test to the facts, the trial judge's findings of fact satisfied the requirements of the but-for test in respect of two of the defendant physicians and the Resurfice material contribution test in respect of the third defendant physician. See 2010 ABCA 64 at paras. 22, 23, 29, 30-34 of the dissenting reasons. The dissenting judge wrote, ibid. at para. 32: "Given the current lack of scientific knowledge (versus a lack of evidence or proper consideration of the evidence by the trial judge) that would allow a court to find that 'but for' Dr. Sevcik's conduct he [the plaintiff] would have lost his legs in any event, I am of the view that the preconditions for bypassing the "but for" test have been met (see Resurfice at para. 25) and the "material contribution" test was properly applied." [Words in square brackets added.] That is the extent of the dissenting judge's explanation of her understanding of the meaning of Resurfice material contribution.

208

Supra note 112.

209

Supra note 35. 
alter the state of the law on causation. Rather it confirmed that "the basic test for determining causation remains the 'but for' test". ${ }^{211}$ Frazer v. Haukioja asserts that Resurfice material contribution is a test for factual causation. ${ }^{212}$ B.(M.). v. 2014052 asserts that liability under Resurfice material contribution is solidary (joint and several) not proportional (several). ${ }^{213}$ This is conclusion is consistent with the premise that Resurfice material contribution in merely a clarified restatement of Athey material contribution. ${ }^{214}$ All of these statements are obiter. None are supported by any analysis of the Resurfice material contribution doctrine. All are explicable on the premise that the judges involved viewed the Resurfice material contribution doctrine as, in substance, the Athey doctrine with revised criteria defining when the doctrine is available.

A few trial judges have made useful statements about Resurfice material contribution which have not yet been formally acknowledged in the appellate jurisprudence. In Farrant $v$. Latkin, the trial judge wrote that "the standard of 'impossible to prove' is murky". ${ }^{215}$ In Rice v. Condran, ${ }^{216}$ the trial judge wrote that "the plaintiff cannot be the cause of that impossibility". In Frazer v. Haukioja, the trial judge seems to have realized that the effect of Resurfice is to turn cases where, before Resurfice, the finding that factual causation had been established would have been made by applying Athey material contribution - meaning the judge or jury found that the but-for test was "unworkable" - into cases where the but-

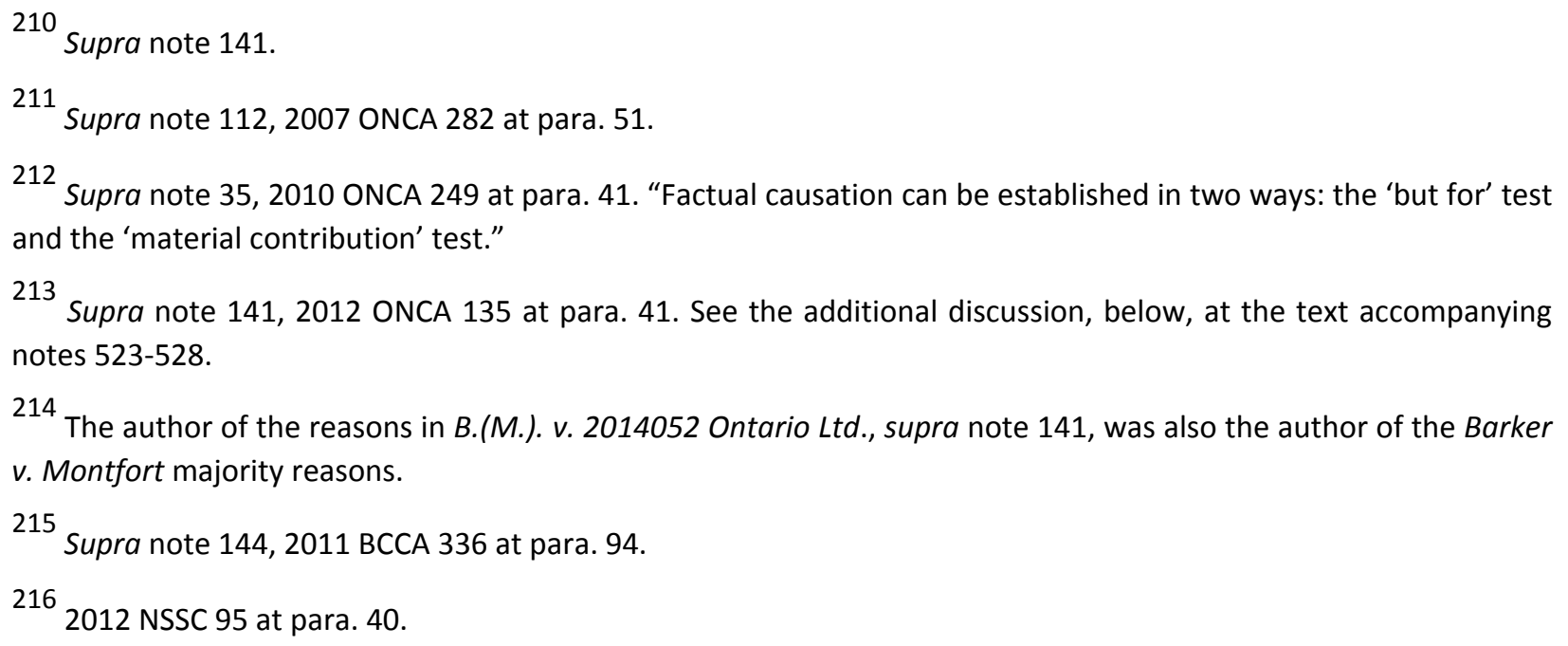


for test is held to be workable and to produce the same conclusion. ${ }^{217}$ However, where the law is set out, most trial reasons contain nothing more than a quotation, or paraphrase, of the Resurfice material contribution requirements followed by a statement that the but-for test governs. In the few cases where trial judges have held the use of the but-for test was impossible in the sense explained in Resurfice, whatever the judge understood that sense to be, the explanation given amounts to nothing more than a quotation or paraphrase of Resurfice. Where there is an attempt at an explanation, the explanation amounts to nothing more than the assertion that it was or was not impossible for factual causation to be proven or disproven using the but-for test. There is no adequate (if any) explanation why the facts made it impossible for the plaintiff to garner and adduce sufficient evidence for a valid inference, on the balance of probability, that a defendant's negligence was a cause. ${ }^{218}$

What is missing in all of the trial decisions purporting to apply Resurfice material contribution is any explanation of why "it would [have] offend[ed] basic notions of fairness and justice to deny liability by applying a 'but for' approach." ${ }^{219}$ None of the cases explain why the particular plaintiff should be favoured over other plaintiffs whose actions fail because they were unable to establish factual causation on the balance of probability. Regardless of the trial judge's intentions, these cases leave the impression that, ultimately, the trial judge's justification was no more than that he or she thought that the defendant ought to be held liable because the defendant was negligent in circumstances in which the defendant ought to be "punished" for that negligence and that negligence could have been a cause of the injury. None of the decisions admit that.

The Resurfice material contribution doctrine requires the plaintiff establish that "the injury sustained by the plaintiff falls within the ambit of the risk created by the defendant's breach

\footnotetext{
217 Supra note 35, 2008 CanLII 42207 at para. 214 (Ont. S.C.J.).

218 The trial decisions in each of the following cases are paradigmatic: Farrant v. Latkin, supra note 144 at paras. 94-95. Clements, supra note 146; Leslie v. S \& B Apartment Holding Ltd., 2011 NSSC 48 at paras. 40-44; Zazelenchuk v. Kumleben, 2007 ABQB 650; and Mainland Sawmills Ltd. v. USW Union Local - 1-3567, 2007 BCSC 1433,62 C.C.E.L. (3d) 66.

219 Resurfice, supra note 1 at para. 25.
} 
of a duty of care". ${ }^{220}$ Any facts underpinning that conclusion would have to be established on the balance of probability. ${ }^{221}$ While it is Resurfice's second-listed general requirement, it is the first requirement the plaintiff must establish. If the plaintiff does not, the court never gets to the causation question. The action must be dismissed. ${ }^{222}$ If there is no duty of care, or no breach, or no actionable injury if there was duty and breach, then causation is not relevant. All issues of past fact must be proved on the balance of probability. ${ }^{223}$

The requirements of Resurfice material contribution may be easier to understand if restated to include the implicit prerequisites. ${ }^{224}$

1. The injury sustained by the plaintiff falls within the ambit of the risk created by the defendant's breach of a duty of care. ${ }^{225}$ This also means the injury the plaintiff alleges must be one the law recognizes as a compensable injury. If the injury is not recognized as a compensable injury even if there is a duty of care, or if there is no duty of care, everything else is irrelevant. The action must be dismissed.

2. The plaintiff has to establish that a duty of care exists and that the defendant breached the duty of care.

3. The plaintiff has not established on the balance of probability that the defendant's negligence was a probable cause.

220 Ibid.

221 McDougall, supra note 154.

222 It is now accepted that the causation inquiry is not undertaken until after the duty of care, standard of care, and breach of standard inquiries. See Klar, Tort Law, supra note 25 at 429. See also Bafaro v. Dowd, 2010 ONCA 188 at paras. 35-36, 260 O.A.C. 70 and McArdle Estate v. Cox, 2003 ABCA 106 at para. 25, [2003] 6 W.W.R. 264.

223 See Athey, supra note 14 at para. 27. See also supra note 154.

224 The order in which the requirements are listed is dictated by what is involved in their proof and the practicalities of litigation. For example, whether the injury is legally compensable at all is a question of law which will need little evidence.

225 Resurfice, supra note 1 at para. 25. 
4. The defendant has not established on the balance of probability that the defendant's negligence was not a probable cause. ${ }^{226}$ Resurfice does not mention this requirement. The better view is that it is implicit in the Court's explanation of the doctrine, at a minimum in the fairness and justice requirement.

5. It is impossible, for qualifying reasons, for anyone to prove or disprove that the defendant's negligence caused the plaintiff's injury using the but-for test. The literal text of Resurfice is the plaintiff must establish that is impossible for the plaintiff to prove on the balance of probability that the defendant's negligence caused the plaintiff's injury using the but-for test. ${ }^{227}$ The better interpretation is that the Supreme Court did not mean the particular plaintiff but meant that, for qualifying reasons, factual causation cannot be proved or disproved on the balance of probability by anybody. ${ }^{228}$

6. The impossibility must be due to factors that are outside of the plaintiff's control. An example of qualifying impossibility is one created by the current limits of scientific knowledge. $^{229}$

226 Bohun v. Segal, supra note 146 at paras. 52-53 is authority for this proposition. Clements, supra note 146 could be an example of this rule. It appears, from the Court of Appeal reasons, that the defendant's expert evidence was that the accident would have occurred even if the motorcycle had been travelling at the speed the trial judge held was the proper speed for the conditions: see 2010 BCCA 581 at paras. 23, 34. However, the Court of Appeal held it did not have to decide whether this was the evidence because Resurfice material contribution was not applicable on the facts favourable to the plaintiff: ibid. a para. 37. See Brown and Cheifetz, "Inferences of Causation", supra note 191 on this aspect of Clements.

227 The text of Resurfice, supra note 1, para. 25, literally refers only to the plaintiff in the action.

228 See Farrant v. Latkin, supra note 144, 2008 BCSC 234 at paras. 94-95; Vaughan Black and David Cheifetz, "Through the Looking Glass, Darkly: Resurfice Corp. v. Hanke" (2007) 45 Alta. L. Rev. 241 at 249 [Black and Cheifetz; "Looking Glass"]. The tenor of the discussions in all of the British Columbia Court of Appeal decisions is that it is the generic plaintiff. That the fairness and justice requirement (discussed in Chapter 3.2.4) focuses on the objective (generic) plaintiff's position is support for the view that it is the objective plaintiff in the impossibility requirement. The United Kingdom position under the Fairchild version of material contribution is objective: "any person". See Farrant v. Latkin, supra note 144, 2011 BCCA 336 at para. 94 and Black and Cheifetz; "Looking Glass", ibid. at 249 .

229 Resurfice, supra note 1 at para. 25 [internal quotation marks omitted]. 
7. It would offend basic notions of fairness and justice to deny liability merely because the particular plaintiff is unable to satisfy the but-for test. ${ }^{230}$

As indicated, Resurfice does not explicitly state that a precondition to the application of the Resurfice material contribution doctrine is that the defendant has not established, on the balance of probability, that the defendant's negligence was not a factual cause. Nonetheless, the precondition is implicit in the fairness and justice requirement. "In those exceptional cases where these two requirements are satisfied, liability may be imposed, even though the "but for" test is not satisfied, because it would offend basic notions of fairness and justice to deny liability by applying a 'but for' approach." 231 "Applying a 'but for' approach" has to be understood to mean that the factual causation cannot be proved or disproved, on the balance of probability. It cannot offend basic notions of fairness and justice to deny liability where a defendant is permitted to establish, and has established, that the defendant's negligence was not a factual cause on the balance of probability. ${ }^{232}$

$230 \mathrm{Ibid}$. at paras. 25, 29. The text of para. 29 is quoted supra at note 19. The second sentence of para. 29 states the Court of Appeal "erred in applying the material contribution test in circumstances where its use was neither necessary nor justified". It is difficult to see what the phrase "neither necessary nor justified" could add. The use of any version of material contribution was not necessary or justified because the but-for test was applicable. If the design of the machine had been negligent, It would have possible to prove, on the balance of probability, whether that negligence was a cause of Hanke's failure to realize the hot water hose was in the gasoline tank if in fact it was a cause. Hanke had testified. He had to have testified he was confused or, at the least, that he had no recollection. The trial judge found that Hanke was not confused. The better view is that para. 29 does not add to or qualify anything the Court said about material contribution in paras. 24-28 but was intended only as brief summary of the Court's explaining why the Alberta Court of Appeal erred in using any version of a material contribution test.

231

Ibid. at para. 25.

232 "Where the defendant Is permitted to" because, in some instances, a rule of law may prevent the defendant from leading evidence which, if accepted, would establish on the balance of probability that the defendant's negligence was not a factual cause. "General rule" because, as the learned intermediary rule established in Hollis, supra note 121, shows, there may be instances where the court will presume, on a non-rebuttable basis, that a defendant's negligence was a probable cause. The defendant will not be allowed to introduce evidence to rebut that presumption, even if the evidence could show that the negligence was not a cause. In addition, the concurring reasons of Rand J. in Cook v. Lewis, supra note 41, imply that there are other instances in which the conduct of the defendant may be a basis for refusing to dismiss the action even though the existing evidence requires the conclusion that the defendant's negligence was not a factual cause. The uncertain status of the spoliation doctrine falls within this area. In common law Canada, spoliation is currently only a rule of evidence. It is not an independent tort. However, the Supreme Court of Canada has not yet ruled on this issue. The current status of spoliation case law is discussed in Holland v. Marshall, 2008 BCCA 468 at paras. 58-81, 301 D.L.R. (4th) 371. 
In any event, the requirement that the defendant not have disproved factual causation on the balance of probability is necessarily implicit in both the impossibility and fairness and justice requirements, so long as it remains Canadian law that past events, once proven on the balance of probability, are treated as certainties. Athey states:

... [P]ast events must be proven, and once proven they are treated as certainties. ... $[T]$ he negligent conduct either was or was not a cause of the injury. The court must decide, on the available evidence, whether the thing alleged has been proven; if it has, it is accepted as a certainty. ${ }^{233}$

Resurfice does not mention this rule. Any suggestion the Court intended to modify or abolish it is not plausible. It follows that the situation the Court referred to when it wrote "it would offend basic notions of fairness and justice to deny liability by applying a 'but for approach" $^{234}$ is only the situation where the action is dismissed because the plaintiff failed to establish factual causation on the balance of probability under but-for and the defendant did not establish, on the balance of probability, that the defendant's negligence was not a factual cause.

There are four generic fact situations which should never pose a problem for the courts because the cases never get to the point where the judge has to decide if Resurfice material contribution could apply. The first is where the parties agree, correctly, that the but-for test is applicable. The second is where the plaintiff does not make the argument that Resurfice material contribution applies if but-for does not. The third is where the judge accepts a theory of the case, whether advanced by the plaintiff or the defendant, which is based on the premise that factual causation could be proved by the plaintiff on the balance of probability. This can be seen as a version of the second example. In each instance, it is not open to judges to decide a case on grounds not raised at trial. ${ }^{235}$

233 Athey, supra note 14 at para. 28 [citations omitted].

234 Resurfice, supra note 1 at para. 25.

235 For Ontario: Labatt Brewing Co. Ltd. v. NHL Enterprises Canada, L.P., 2011 ONCA 511 at paras. 5-9; for Alberta: Sumner v PCL Constructors Inc., 2011 ABCA 326 at para. 26; for British Columbia: Randhawa v. 420413 B.C. Ltd., 2009 BCCA 602 at para. 26. 
The fourth example is the problem caused by duplicative factual causation. An instance of duplicative factual causation is not an instance of factual causation without probability. Duplicative causation means the proven existence, on the balance of probability, of multiple sufficient causes. Doctrinal problems arising where the evidence is not sufficient to allow the judge or jury to select validly any one or more of the potential causes as an actual cause are distinct from the doctrinal problems caused by the existence of duplicative causation. The doctrinal issues that duplicative causation creates have nothing to do with any insufficiency in the amount of evidence, or the quality of the evidence, needed to establish factual causation. The issue is an extent of legal responsibility question: what is the effect on the potential for liability of one wrongdoer whose conduct was a sufficient cause that there is another sufficient cause unrelated to the former's conduct? The better view of Resurfice is that Supreme Court did not intend to deal with the problem that duplicative causation causes for the but-for test. ${ }^{236}$ The Supreme Court did not intend to suggest that the solution for duplicative causation is provided by a test that is premised on the assumption that it is impossible for anyone to establish, on the balance of probability, that the negligent conduct was or was not a factual cause.

It is likely to be clear enough in most cases whether there is any need to consider the Resurfice material contribution test, ${ }^{237}$ assuming both that the plaintiff has failed to establish factual causation on the balance of probability under the but-for test (or any other available method) and the defendant has not disproved factual causation on the balance of probability. ${ }^{238}$ That much seems necessarily implicit in the fairness and justice requirement.

\footnotetext{
236 The discussion of Fairchild in Knutsen, "Clarifying Causation", supra note 200 at 165, should not be read as a suggestion that Resurfice material contribution is applicable to instances of duplicative causation. The better view is that Knutsen used Fairchild as an example of the situation where there could be more than two alternative sufficient causes.

237 Even if not so obvious that the conclusion strikes "with the force of a five-week-old, unrefrigerated dead fish": see Parts and Electric Motors, Inc. v. Sterling Electric Inc., 866 F.2d 228 at 233 (7th Cir. 1988) where the description is used in a different context.

238

By showing either no general causation (the negligence has no capacity to cause the particular injury) or no specific causation (in the particular case the negligence probably was not a cause of the particular injury). See supra note 4.
} 
The fairness and justice requirement is trivial if it is deemed conclusively satisfied by the plaintiff satisfying the impossibility and ambit of risk conditions. If the requirements of Resurfice material contribution are not satisfied by the mere fact that the plaintiff has been able to satisfy the ambit of risk and impossibility requirements, then, if there is to be any substance to the fairness and justice requirement, the relevant considerations must extend beyond those specific to the claim by the particular plaintiff against the particular defendant. $^{239}$

Last, if the fairness and justice requirement is conclusively satisfied merely by the plaintiff has satisfying the impossibility and ambit of risk conditions, then it is difficult to see any valid basis for ever concluding that it would not offend basic notions of justice and fairness to dismiss any action where the defendant has not established, on the balance of probability that the defendant's negligence was not a cause. That interpretation of the Resurfice material contribution doctrine is inconsistent with the Supreme Court's statements that it applies only in "special circumstances" ${ }^{240}$ and "exceptional cases". ${ }^{241}$ These terms, themselves, indicate that the "justice and fairness" looks outward as well as inward. Both "special" and "exceptional" are comparative. The circumstances of a particular action can be "special" only because there is something about the circumstances of that action that makes it different in a "special" way from seemingly similar circumstances in other actions. The same point applies to "exceptional cases". The point is, then, that there is necessarily an objective component to fairness and justice in the meaning of "basic notions of fairness and justice". 242

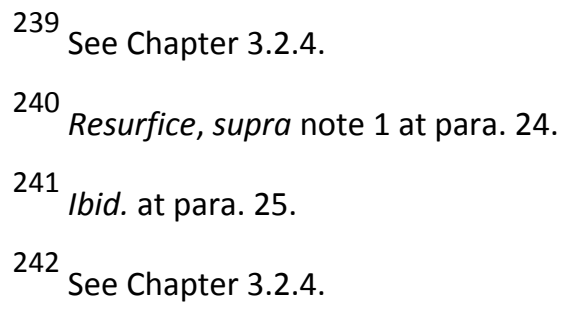




\subsubsection{Impossibility}

\subsubsection{Logical Impossibility and Insufficient Evidence}

The first of the stated prerequisites is the impossibility requirement.

First, it must be impossible for the plaintiff to prove that the defendant's negligence caused the plaintiff's injury using the "but for" test. The impossibility must be due to factors that are outside of the plaintiff's control; for example, current limits of scientific knowledge. ${ }^{243}$

The cursory explanation of the impossibility requirement ${ }^{244}$ creates a legion of questions. The meaning of the impossibility requirement is one of the two keys to the meaning of Resurfice material contribution. The other is the meaning of the fairness and justice requirement. ${ }^{245}$ The second requirement - the ambit of risk requirement - is not useful. It provides no assistance in separating the exceptional cases, to which Resurfice material contribution may apply, from those to which it will not. The ambit of risk requirement is an essential aspect of all negligence actions. ${ }^{246}$ This section examines what seem to be the major questions in the meaning of the impossibility requirement.

Does the impossibility requirement apply only to cases where, for qualifying reasons, there is not sufficient evidence to determine, on the balance of probability, whether the negligence of a defendant is or is not a factual cause? In this instance, the but-for test would provide a valid answer if the evidence existed; however, the available evidence is not sufficient to produce a valid answer if the test is applied properly. Or, is the requirement also intended to also describe cases where there is factual causation but the but-for test cannot be validly used to establish that? The better view is the former, only. As indicated, there are instances of factual causation which can be established on the balance of probability but cannot be

\footnotetext{
243 Resurfice, supra note 1, para. 25.

244 Ibid., paras. 26-28.

245 See Chapter 3.2.4.

${ }^{246}$ See Chapter 3.2.3.
} 
validly identified by the but-for test. One example is duplicative causation. ${ }^{247}$ It must be assumed that the Court was aware of the intrinsic doctrinal limitations of the but-for test.

Does "plaintiff" mean the specific plaintiff, so that requirement is satisfied by an inquiry into the circumstances of the particular plaintiff? Or, was the reference intended to be an objective inquiry into the abilities of a hypothetical plaintiff with unlimited resources? The problem in the text of Resurfice is the focus on the impossibility of the particular plaintiff proving causation on the balance of probability if the impossibility requirement is read literally. The better position is that the Supreme Court intended the Resurfice material contribution test to apply only where, for qualifying reasons, it is impossible for anyone to establish validly, on the balance of probability, that a defendant's negligent conduct is or is not a factual cause of injury. The phrase "impossible for the plaintiff to prove" should be understood to mean "impossible for anyone to either prove or disprove even if every bit of evidence that could ever be available to the moment of trial were put before the court." 248 Unless "impossible to prove" is interpreted in this manner, the impossibility requirement is too easily satisfied. ${ }^{249}$

There will be many cases where, for reasons outside a plaintiff's control, it is impossible for the plaintiff to demonstrate causation. ... There are an infinite number of cases where, for reasons beyond a plaintiff's control which have nothing to do with

\footnotetext{
247 See supra note 25 and the text in the paragraph after note 235 . In addition to instances of duplicative causation, there is at least one other known instance of factual causation which cannot be validly identified by the but-for test. It occurs where the set of causal factors which is a cause of the injury is, itself, made up of a number of factors which are cumulatively sufficient but are individually neither sufficient nor necessary. They are not individually necessary because the causal set is composed of more of these factors than is needed to make it a cause. A form of the example used in causation literature has a person drinking water that contains a poison. Four or more people each put in $1 / 3$ of the required dose. The victim, therefore, drank $4 / 3$ of the required dose. Each of the doses was a factual cause of the injury even though each was, individually, neither sufficient nor necessary. See Richard W. Wright, "Acts and Omissions As Positive and Negative Causes" in Emerging Issues in Tort Law, eds. Jason Neyers, Erika Chamberlain, and Stephen Pitel (Oxford: Hart Publishing, 2007) 287 at 297, Richard W. Wright, "The Grounds and Extent of Legal Responsibility" (2003) 40 San Diego L. Rev. 1425 at 1443-44, text accompanying nn. 58-64, and Wright, Causation in Tort Law", supra note 18 at 1792-94.

248 See Black and Cheifetz, "Looking Glass" supra note 227 at 249. This is essentially the analogous impossibility requirement in Fairchild: supra note 89 at paras. 42-43, 46, 61, 72, 113, where the focus is clearly on whether anyone could prove or disprove factual causation, not whether the particular plaintiff can or cannot. See particularly para. 43.

249

Black and Cheifetz, "Looking Glass", ibid. at 249. See Chapter 3.2.4.
} 
what caused what, the plaintiff cannot demonstrate that the defendant's actions had any causal factual relationship with the plaintiff's injury. In many of those cases, that creates no dissatisfaction with the but-for test, nor should it. ${ }^{250}$

This objective interpretation of the meaning of the impossibility requirement seems to be what is meant by statements that the impossibility requirement requires that that it be "truly impossible" to prove factual causation on the balance of probability. ${ }^{251}$ It is also the interpretation consistent with the premise that there is an overriding, objective, fairness and justice requirement. The requirements of the Resurfice material contribution doctrine are too easily satisfied unless there is some limitation to the doctrine's applicability, in a particular case, even if the two "general requirements" are met. ${ }^{252}$

Is the "current limits of scientific knowledge" condition only an example of an instance creating relevant impossibility, or is it a necessary limiting condition ${ }^{253}$ Must the problem that renders the plaintiff unable to establish factual causation on the balance of probability result from the current limits of science? Or, does the phrase merely set out an example to help identify the essential characteristics of a reason that produces qualifying impossibility? The grammatical meaning of the text of the requirement is the "an example"

250 Ibid. at 249.

251 See Jackson v. Kelowna Hospital, supra note 178 at para. 22 and Farrant v. Latkin, supra note 144, 2008 BCSC 234 at paras. 94-95. Farrant cites the discussion in Black and Cheifetz, "Looking Glass".

252 See Chapter 3.2.4.

253 The provenance of the "current limits of current limits of science" phrase undoubtedly includes Fairchild, supra note 89. Fairchild set out six preconditions to the application of the United Kingdom's version of its version of a doctrine allowing causation to be established on the basis of fault and a possibility less than the probability of factual causation. The first is "gap in medical knowledge of aetiology such that respective likelihoods of risks cannot be determined". See Brown, "Hegemony", supra note 105 at 448, n. 78. The provenance might also include the summary of Fairchild in Cottrelle, supra note 92 at para. 30. 
interpretation. ${ }^{254}$ The appellate case law, to date, seems to support the "an example" view. $^{255}$

Resurfice sets out two examples of the circumstances making the valid use of the but-for test impossible and permitting, but seemingly not requiring, the use of its version of a material contribution test. The verb used by the court in each case is preceded by "may be". The text of the first example ends with "a material contribution may be appropriately applied" ${ }^{256}$ The text of the second example begins with the phrase "[a] second situation requiring an exception to the 'but for' test may be where". ${ }^{257}$ This permissive, not mandatory, phrasing is connected to the third requirement: that it would "offend basic notions of fairness and justice" if the action were to be dismissed solely because factual causation can neither be proved nor disproved on the balance of probability. ${ }^{258}$

254

Many reasons that neither discuss nor apply Resurfice material contribution paraphrase the Resurfice requirements when setting out causation law and omit the second sentence of the impossibility condition completely; or, omit any version of the phrase "current limits of scientific knowledge".

255

The one aberration is the obiter comments of the majority in Bowes v. Edmonton (City), 2007 ABCA 347. Bowes is not likely not good law, even in Alberta. Bowes was not mentioned in Nattrass v. Weber, supra note 144, the leading Alberta Court of Appeal decision on Resurfice. Bowes seems to ignore the "current limits of scientific knowledge" proviso and does not quote the text of the impossibility requirement. The better view of the facts seems to be that the evidence the plaintiffs needed either still existed and could have been adduced or it once existed. The Court of Appeal unanimously dismissed the action on the grounds that the action had been commenced after the expiration of the limitation period. Two judges on the panel held that the plaintiffs could use Resurfice material contribution to satisfy the causation requirements of the cause of action. The third judge dissented. The dissent points out why the evidence either still existed and could be adduced or once existed and could have been obtained. The majority seem to have understood Resurfice material contribution to be the Athey version producing a finding of factual causation, albeit with restated qualifying conditions. The majority did not refer to Cook v. Lewis, supra note 41. However, the majority's explanation of why it was now impossible for the plaintiffs to prove factual causation on the balance of probability seems to echo Rand J.'s opinion in Cook v. Lewis (ibid. at 840-41) that causation should be presumed where the defendant's conduct impaired the plaintiff's ability to satisfy the burden of proof.

256

Resurfice, supra note 1 at para. 27.

257 lbid. at para. 28.

258

Ibid. at para. 25. See Chapter 3.2.4. 
The first example describes a situation where it is impossible to use the but-for test to determine validly, on the balance of probability, which of two people committed the act that injured the plaintiff. ${ }^{259}$

One situation requiring an exception to the "but for" test is the situation where it is impossible to say which of two tortious sources caused the injury, as where two shots are carelessly fired at the victim, but it is impossible to say which shot injured him: Cook v. Lewis. ... Provided that it is established that each of the defendants carelessly or negligently created an unreasonable risk of that type of injury that the plaintiff in fact suffered (i.e. carelessly or negligently fired a shot that could have caused the injury), a material contribution test may be appropriately applied. ${ }^{260}$

The first example is the situation where the injury was caused by one of two alternative tortious events but the evidence is not sufficient to allow the judge or jury to make a valid choice, on the balance of probability, between the alternatives. In principle, the rationale underlying the Resurfice material contribution doctrine is applicable where there is more than one alternative but not all of the alternatives are tortious. ${ }^{261}$

A puzzling aspect of Resurfice is that Canadian law has an answer for the exact problem posed by the first example, so long as there are only two alternative causes both of which are tortious. The premise in the example, as written, is that the injury was necessarily caused by one of the two sources. Cook v. Lewis $^{262}$ holds that the but-for test applies to this example, albeit with the onus of proof shifted to the defendant. Under Cook v. Lewis, a defendant is held liable if the defendant is not able to establish, on the balance of probability, that the defendant's negligence was not a probable cause. A plaintiff injured in circumstances to which Cook v. Lewis applies does not need the Resurfice material

\footnotetext{
259 Ibid., para 27. The example uses "say" not "prove".

260 Ibid., para. 27 [citation omitted].

261 See Barker v. Corus, supra note 99 (4 alternatives of which 3 were tortious) and Sienkiewicz, ibid., (2 alternatives, 1 tortious). This fact can be seen as a justification for the overriding fairness and justice control. If the evidence were such that it established, on the balance of probability, that both a tortious cause and a non-tortious cause were duplicative sufficient causes, then the action would have to be dismissed, on both causation of injury and damages assessment principles: Athey, supra note 14, paras. 32-33, 41.1. See also infra at the text accompanying notes $456-463$.

262 Supra note 41.
} 
contribution doctrine to succeed against at least one of the two tortfeasors, so long as the plaintiff sues both. If the plaintiff sues both and fails against one of the two, it is because that defendant established, on the balance of probability, that that defendant's negligence was not a factual cause. But, if neither defendant is able to disprove negligence, then both are held liable. However, no case has suggested that the imposition of liability on both is based on the fiction that the conduct of both defendants could be a factual cause. ${ }^{263}$ In order to take the first example out of the facts of Cook v. Lewis, the assumption has to be made that plaintiff's first problem is that the plaintiff cannot establish, on the balance of probability, that the injury was probably caused by one of the two tortious sources and nothing else. But that is not Cook v. Lewis, nor is it the example as written.

The presumed problem in Cook v. Lewis was the fact that the injury was found to have been caused by the negligence of one or two wrongdoers, but the evidence might not have permitted the plaintiff to establish which of the two it was on the balance of probability. The problem in Cook v. Lewis had everything to do with the possibility that the evidence was not sufficient to identify who the shooter was, perhaps but not necessarily due to limits of science. ${ }^{264}$ Snell explains the rule in Cook v. Lewis.

In Cook v. Lewis ... the plaintiff was struck by a bullet fired from the gun of one of his two companions. The evidence supported the theory that they fired simultaneously in the plaintiff's direction when they knew his location. The plaintiff could not prove which shot struck him and therefore on traditional rules, he would fail. The basic premises referred to above did not make good legal sense in this instance. Both defendants were negligent and each asserted that his negligence did not cause the injury. Since the plaintiff could establish that one of them caused the injury, why should not the defendants be required to exculpate themselves by proving their assertions, and failing that, be held equally liable? ... [T] his Court concluded that if it could not be determined which defendant fired the shot that struck the plaintiff, both defendants must be found liable. ${ }^{265}$

\footnotetext{
263 While Athey, supra note 14 at para. 28, states that a finding of causation on the balance of probability is treated as a certainty, that fiction should not be used to convert the policy-based imposition of liability under Cook $v$. Lewis into a fiction of liability imposed on the basis of an actual finding of factual causation.

264 The majority of the Supreme Court believed that "the jury should have been able to decide which one of the defendants fired the shot which struck the plaintiff." See ibid., note 41, [1951] S.C.R. 830 at 843.

265 Snell, supra note 42 at 321 [citation omitted]. See Cook v. Lewis, supra note 41 at 840-842.
} 
Both defendants denied they fired in the direction of the injured person. However, on the evidence the person responsible was one of the two. The passage is an accurate statement of the ratio of the majority in Cook v. Lewis. ${ }^{266}$ The reason for the rule in Cook v. Lewis - that in certain circumstances the onus of disproving causation will be placed on the defendant was to overcome the injustice of the general rule that the plaintiff's action had to fail if he could not prove, on the balance of probability, which of the two hunters had fired the shot that injured him. ${ }^{267}$

Resurfice does not mention the rule in Cook v. Lewis. No case before Resurfice suggested that the result in Cook v. Lewis should be seen as an application of the Athey material contribution test or any other version of a material contribution test. ${ }^{268}$ The Supreme Court did not in Hollis v. Dow Corning Corp., ${ }^{269}$ where the majority affirmed Cook v. Lewis but did not apply it. There is nothing in Resurfice that supports the view the Court intended to revise or overrule Cook v. Lewis. ${ }^{270}$ There is nothing in Resurfice that indicates what gloss on the facts of Cook v. Lewis the Court might have had in mind to take those facts out of the ambit of Cook v. Lewis. As indicated, the only option that takes the facts of the first example out of the ambit of Cook $v$. Lewis is to assume that the plaintiff cannot prove, on the balance of probability, that there are no probable alternative tortious causes other than the two in issue, even though the Court did not mention that. The premise in the case to which Cook $v$. Lewis applies is that the negligence of only one of the two wrongdoers was actually the cause. However, the premise of Resurfice material contribution is no more than that a wrongdoer's negligence is possibly a cause. There is no premise that the negligence of any of the wrongdoers was probably a cause. In order to make sense of the first example, then, the

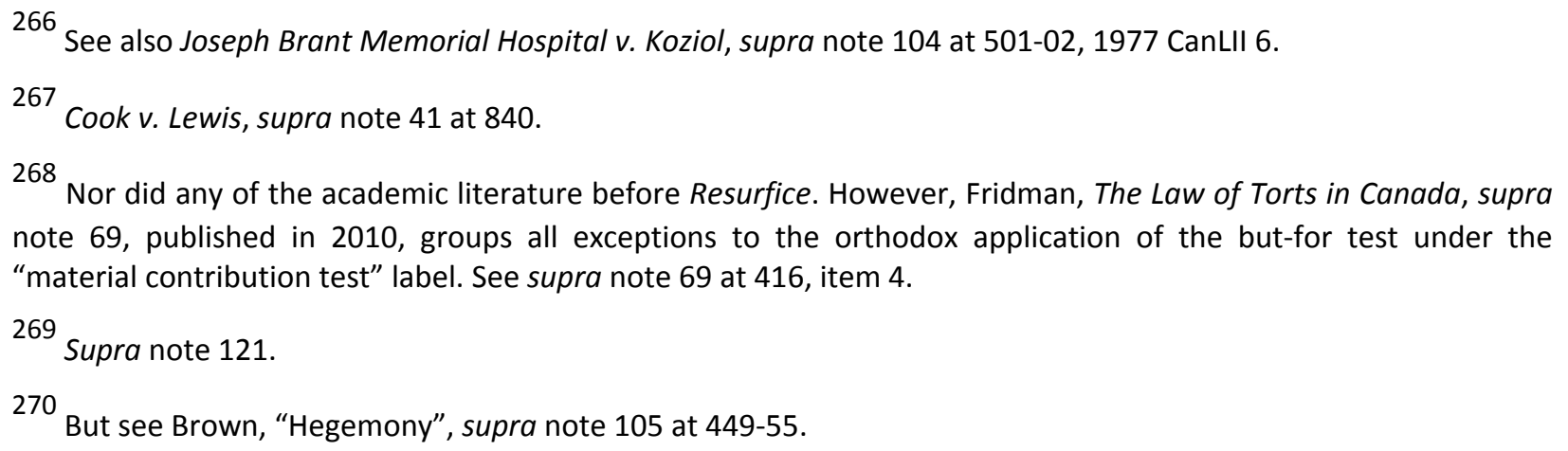


assumption has to be made that the plaintiff cannot establish, on the balance of probabilities, that one of the two tortious alternatives was the probable cause, or that the probable cause could only be one of the two tortious alternatives.

As indicated, a plaintiff cannot lose against one of the two tortfeasors where Cook v. Lewis applies, so long as the plaintiff sues both tortfeasors, because Cook v. Lewis applies only where, on the balance of probability, the cause of the injury could only have been the negligent conduct of one or the other of the two tortfeasors. However, under Resurfice material contribution, if there is a fairness and justice requirement, there is necessarily a possibility that the doctrine would not be applied. Thus, the plaintiff has the risk of losing completely, on causation grounds, if Resurfice material contribution is applied to facts to which the rule in Cook v. Lewis would have applied before Resurfice. The better conclusion is that the Court's use of the assumed facts of Cook v. Lewis to describe the problem of insufficient evidence in instances of alternative causation, without clarification of that use, was a mistake. ${ }^{271}$

The first example, as set out, is also proof enough that Resurfice material contribution is not intended to produce a finding of factual causation. On the facts of the first example, the actual cause can be only the action of one of the two tortfeasors, yet the doctrine permits both to be held liable. There is no valid reason to assume the Supreme Court intended that the application of the material contribution doctrine produce the legal fiction that the conduct of tortfeasors held liable because of its application was actually a cause of the injury. $^{272}$

The causation problem in the second example has been called "decision causation" and "dependency causation". ${ }^{273}$ The second example describes as a "situation ... where it is

\footnotetext{
271 Ibid. at 452, at the text accompanying nn. 92-93.

272 We should assume the Supreme Court was aware that the House of Lords had rejected the legal fiction explanation of Fairchild, supra note 89, in Barker v. Corus, supra note 99.

273 See Chapter 3.2.2.2.
} 
impossible to prove what a particular person in the causal chain would have done had the defendant not committed a negligent act or omission, thus breaking the 'but for' chain of causation". 274

A second situation requiring an exception to the "but for" test may be where it is impossible to prove what a particular person in the causal chain would have done had the defendant not committed a negligent act or omission, thus breaking the "but for" chain of causation. For example, although there was no need to rely on the "material contribution" test in Walker Estate v. York Finch General Hospital, this Court indicated that it could be used where it was impossible to prove that the donor whose tainted blood infected the plaintiff would not have given blood if the defendant had properly warned him against donating blood. Once again, the impossibility of establishing causation and the element of injury-related risk created by the defendant are central. ${ }^{275}$

The example means that the evidence does not exist from which the judge or jury can validly make a conclusion, on the balance of probability, about what the third person would have done. The problem outlined in the second example is the problem that Canadian law resolves by the modified objective test in informed consent medical malpractice cases what a person probably would have done if provided certain information. ${ }^{276}$

The statement that concludes the second example - "Once again, the impossibility of establishing causation and the element of injury-related risk created by the defendant are central" $^{277}$ - highlights a problem in the Court's explanation of the parameters of the Resurfice material contribution test. The assertion that the "element of injury-related risk" is a central element of the exceptional instances to which the test may apply is not useful because "injury-related risk" is an essential element of all duties of care. However, it is the creation of unreasonable risk, not merely the creation of risk. ${ }^{278}$ Resurfice must be

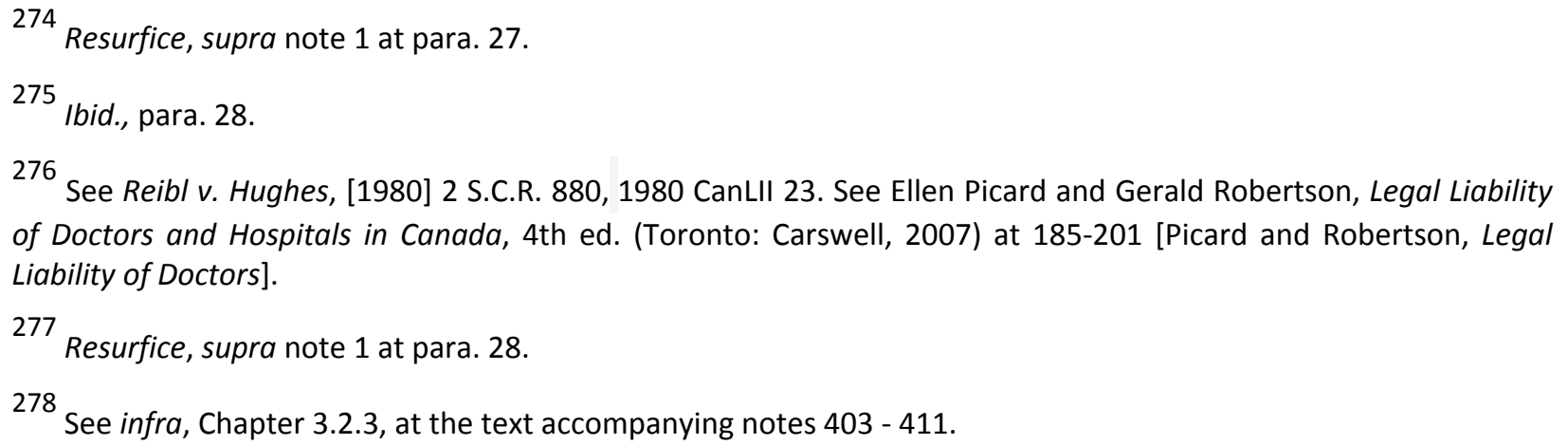


understood to have meant unreasonable risk because the Resurfice material contribution doctrine is applicable only where the defendant is found to be negligent.

The Supreme Court took the facts of Walker Estate ${ }^{279}$ as an example of a situation which might create this impossibility. Appellate judges in British Columbia ${ }^{280}$ and the Northwest Territories ${ }^{281}$ have noted, before and after Resurfice, that "[t]he but-for test of causation has traditionally been applicable even in cases where the hypothetical question requires prediction of human reaction". ${ }^{282}$ The Supreme Court held the but-for test was applicable to the facts of Walker Estate even though it was not necessary to use that test. ${ }^{283}$ Walker Estate shows the mere fact that the factual causation decision requires a conclusion about what some person other than the plaintiff would have done if the defendant had not been negligent does not mean that the counterfactual analysis through which the but-for test functions cannot be validly used to produce the inferences of necessary for the judge or jury to decide the factual causation issue on the balance of probability. Again, it is important to recall that tort law's threshold of confidence is probability, not certainty. Prior to Resurfice, the plaintiff's action was to be dismissed if the plaintiff failed to establish factual causation on the balance of probability, whatever the applicable test was. Resurfice states that the material contribution doctrine applies only in "exceptional cases". ${ }^{284}$ That means the ordinary case producing this problem must still result in a dismissal. ${ }^{285}$ Resurfice does not provide any means of identifying the exceptional cases, unless it is the content of the "basic notions of fairness and justice" ${ }^{286}$ proviso. That approach requires the conclusion that the

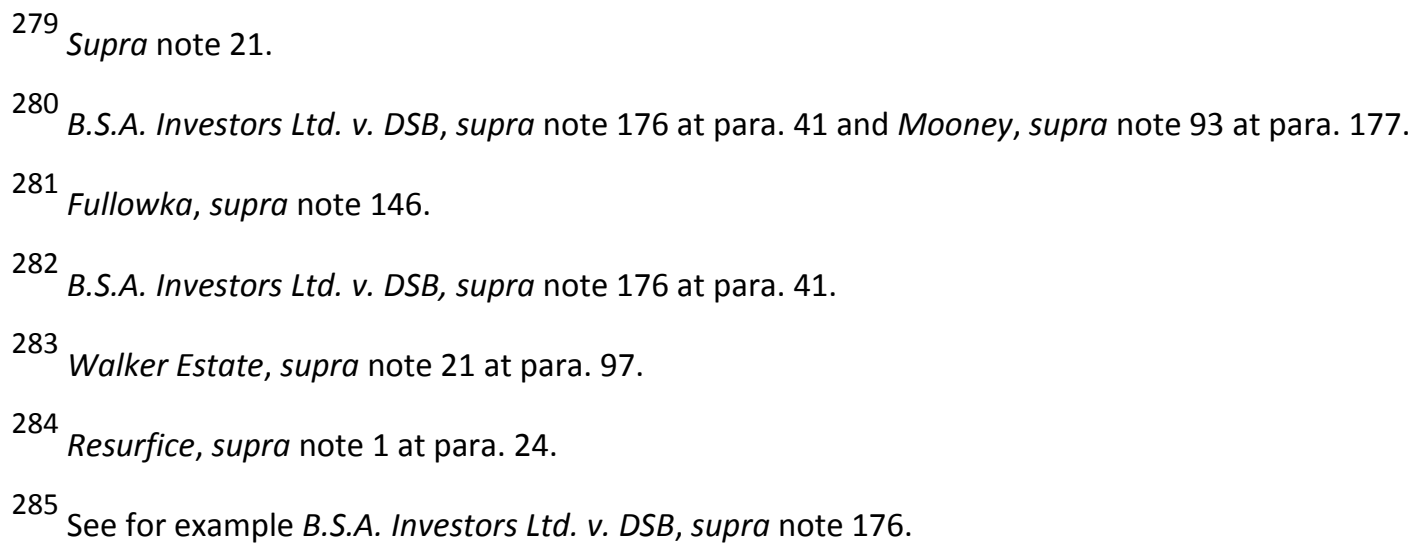


fairness and justice proviso is a separate requirement. ${ }^{287}$ Again, however, Resurfice does not provide any direction on the meaning of that proviso.

According to Resurfice, "the impossibility of establishing causation and the element of injuryrelated risk created by the defendant are central" to the reason that an exception is required to the but-for test. ${ }^{288}$ One of the problems in the Court's explanation of the parameters of Resurfice material contribution is the lack of clarity in the meaning of "impossibility". Perhaps this is due to the brevity of the Resurfice discussion. The brevity would be less of a problem if the Supreme Court had specifically acknowledged any of its sources for the material contribution doctrine, so that the sources would provide context. Both examples do not describe situations where it is necessarily impossible to ever establish factual causation on the balance of probability in every instance of those examples. Rather, the examples describe instances where, in a particular, case, there might not be enough admissible evidence for a valid decision to be made on the balance of probability. That is more apparent in the second example where, in some instances, the answer to the question of the causal status of the defendant's negligence may be provided by believing or rejecting the third person's evidence as to what he or she would have done if the defendant's negligence had not occurred. But, the plaintiff's problem in every case where there is a valid conclusion that the plaintiff failed to establish factual causation on the balance of probability, and the defendant did not disprove factual causation on the balance of probability, is that plaintiff failed to adduce the required evidence.

Before Resurfice, the plaintiff's action was supposed to be dismissed if the plaintiff failed to adduce that evidence, except where the Cook v. Lewis exception (alternative causes) ${ }^{289}$ or

\footnotetext{
${ }^{286}$ Resurfice, supra note 1 at para. 25

287 See Chapter 3.2.4.

${ }^{288}$ Resurfice, supra note 1 at para. 28.

289 See supra at the text accompanying notes 264-267.
} 
the Hollis v. Dow Corning Corp. exception (the learned intermediary rule) ${ }^{290}$ applied. Whatever the Athey material contribution test meant as an exception to the but-for test, it still required the plaintiff to adduce evidence sufficient to show that the defendant's negligence was a probable cause. ${ }^{291}$ It is clear that the Supreme Court did not intend the Resurfice material contribution analysis to be undertaken in all cases where the plaintiff fails to establish factual causation on the balance of probability, whether under the but-for test or one of the exceptions, merely because the plaintiff fails to establish factual causation on the balance of probability. The Court's description of the cases to which the Resurfice material contribution doctrine will apply as "special circumstances" 292 and "exceptional cases" $^{293}$ is sufficient proof. This desire to limit the applicability of Resurfice material contribution to cases that are "special" or "exceptional" explains the Court's attempt to limit the meaning of "impossibility" in the first requirement by the phrase "due to factors that are outside of the plaintiff's control; for example, current limits of scientific knowledge". ${ }^{294}$ It also explains why some judges, since Resurfice, have offered "truly impossible" as useful summary of the meaning of the impossibility requirement. ${ }^{295}$ Unfortunately, the explanations offered of "truly impossible" in these cases are the examples in Resurfice. ${ }^{296}$

As indicated, the triggering circumstances described by the first example necessarily contain the possibility the court will decide that the negligence of none of the tortfeasors was a possible cause, even if example the Court chose does not contain that possibility. That

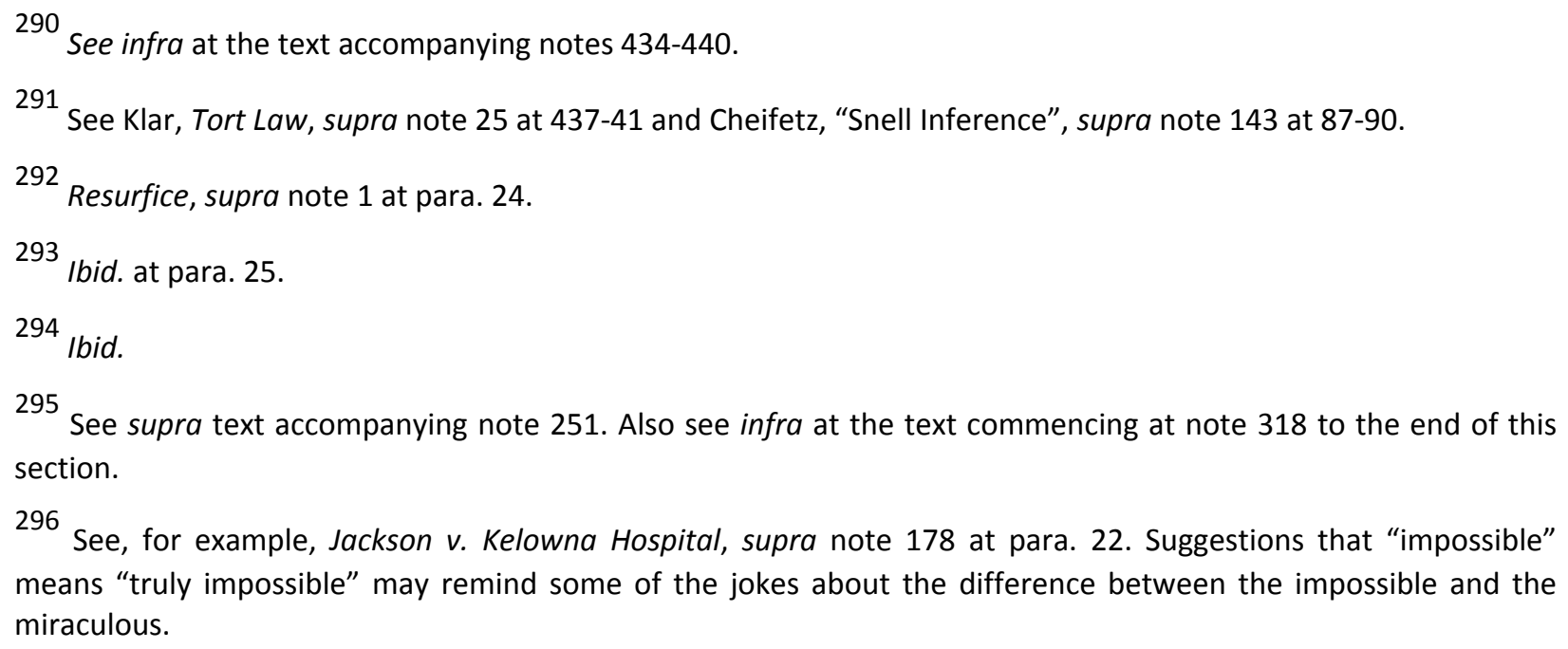


possibility does not exist in the facts of the example that the Supreme Court chose because, in that example, the assumption was that the cause was the conduct of one or the other of the two tortfeasors. However, the example was offered as nothing more than one example of an instance of qualifying impossibility. It does not make sense to assume the Court intended Resurfice material contribution to apply only to instances where all of the negligent persons are known so that the only question to decide is whether the conduct of one or more of them was a possible cause. ${ }^{297}$ In the first example, the question is whether the conduct of any one or more of the assumed tortfeasors was a possible cause. A complete "no" must be a valid possibility. That is, it must be a valid possibility that there will be a decision that the evidence does not establish that the negligence of any of them is a possible cause for the purposes of Resurfice material contribution.

The second example does not contain the possibility that the conduct of a negligent defendant will be found to not have been a factual cause. It is based on the assumption that the conduct of the negligent defendant was a necessary component of circumstances sufficient to cause the injury. That is, the premise of the second example has to be that the negligent conduct of the defendant, which conduct the third person may or may not have taken into account in deciding what to do, was a necessary part of a set of facts sufficient to be a cause of the injury. Therefore, the issue posed by the second example is only whether the negligence of the defendant is to be treated as a legal cause. Otherwise, there is no purpose in inquiring into the legal effect of the conduct of the third person on the causal status of the negligent conduct of the defendant. This is point is necessarily implicit in the Court's "breaking the but-for chain of causation" description. ${ }^{298}$

The two examples set out in Resurfice are not intended to be exhaustive. They are not intended as definitions of the meaning of qualifying impossibility. They are merely examples of facts that amount to qualifying impossibility. That is made clear by the manner by which

\footnotetext{
297 Fairchild, supra note 89 was decided on this assumption. It was abandoned in Barker v. Corus, supra note 99. We should assume the Supreme Court knew this.

298 Resurfice, supra note 1 at para. 28.
} 
each is introduced: "Without dealing exhaustively with the jurisprudence, a few examples may assist in demonstrating the twin principles just asserted"; 299 "One situation requiring an exception"; 300 and, "A second situation requiring an exception". ${ }^{301}$ In addition, it is difficult to see how the evidentiary problem in the second example is one of the current limits of scientific knowledge, unless the Supreme Court had in mind the absence of any known to be valid mechanism of mind reading of living persons, or recovering the memories of the dead. This is more evidence that that "current limits of scientific knowledge" proviso is only an example of a sufficient reason for qualifying impossibility, not the definition of that reason.

Neither Resurfice example addresses the problems of proof caused by indivisible injury, whether the case has successive, separate, incidents held to cause indivisible injury or one or more incidents with consequences superimposed over pre-existing conditions that are not due to actionable, or at least once actionable, events. ${ }^{302}$ The better view is that Resurfice material contribution was not intended to apply to cases where the judge or jury concludes that the injuries from multiple incidents, whether or not superimposed upon pre-existing conditions as explained above, amount to indivisible injury. This is a necessary consequence of the definition of indivisible injury. There is indivisible injury only where there are multiple causes of injury and the negligence of the defendant is held, on the balance of probability, to be one of the causes of the injury, regardless of whether the multiple causes are cumulative (as in Athey) or could be duplicative or cumulative. "Divisible injuries are those capable of being separated out and having their damages assessed independently. Indivisible injuries are those that cannot be separated or have liability attributed to the constituent causes. “303 The definition of indivisible injury eliminates the need for the court to decide whether the

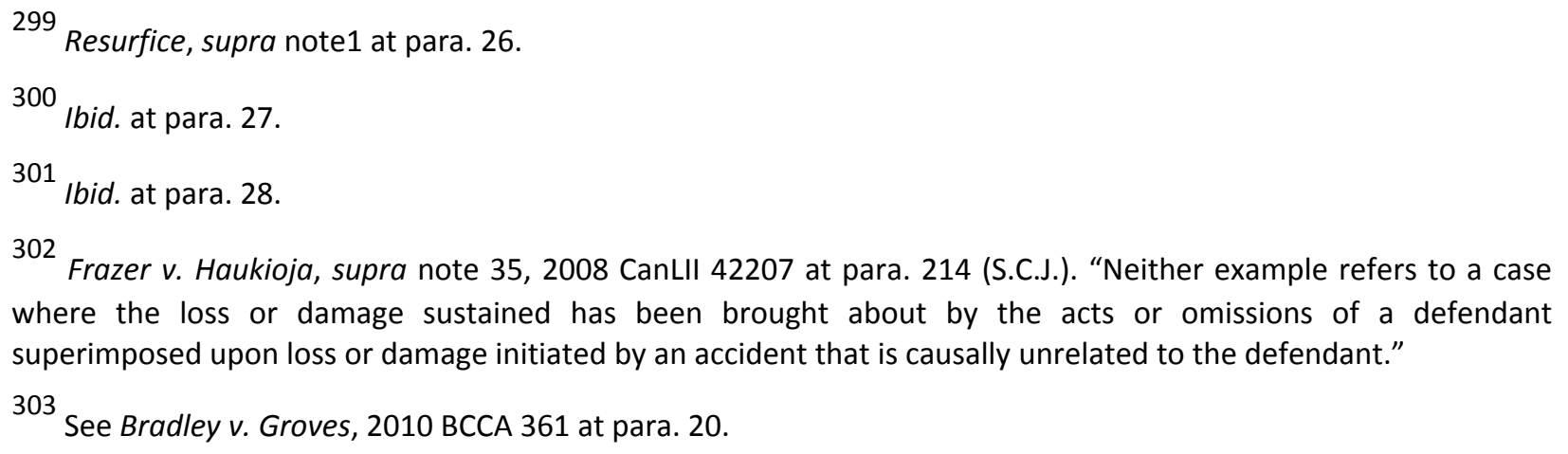


multiple causes are cumulatively necessary of separately sufficient. The conclusion that injury is indivisible deems that injury to have been probably caused by all of the multiple causes found to have been possible causes and produces joint and several liability. ${ }^{304}$

Recall the description in Aristorenas of the nature of the causation problem that was required to trigger the Athey material contribution test. "The test is invoked because of logical or structural difficulties in establishing 'but for' causation, not because of practical difficulties in establishing that the negligent act was a part of the causal chain." ${ }^{305}$ This description succinctly describes the Resurfice examples. What is clear is that both examples are supposed to be something more than merely instances of "practical difficulties in establishing that the negligent act was a part of the causal chain". However, Resurfice does not provide any guidance, any bright line, for the judge or jury for use in those cases where it is not obvious which category the problem of proof invokes.

The Resurfice material contribution doctrine must be capable of applying even where there is only tortfeasor. There is no basis, in principle, or in the text of Resurfice, for restricting the doctrine to instances having more than one tortfeasor. ${ }^{306}$ While the examples that Resurfice offers of instances where the doctrine might apply have two wrongdoers (the facts of the Cook v. Lewis example ${ }^{307}$ ) or could have two wrongdoers (the facts of the Walker Estate example ${ }^{308}$ ) both instances are just examples. There are at least two tortfeasors in the Walker Estate example if the blood donor was also negligent. There is only one if the blood

\footnotetext{
304 Ibid. at 20-25 citing Athey, supra note 14, and E.D.G. v. Hammer, [2003] 2 S.C.R. 429, 2003 SCC 52, See also B.(M.) v. 2014052 Ontario, supra note 141 at para. 60.

305 Aristorenas, supra note 92 at para. 53. In Fisher v. Victoria Hospital, 2008 ONCA 759 at para. 53, n. 14, the Ontario Court of Appeal claimed that the two examples in the Resurfice reasons "would seem to support" the Aristorenas dictum.

${ }^{306}$ The United Kingdom equivalent was applied to a one tortfeasor situation in Sienkiewicz, supra note 99.

307 lbid. at para. 27.

308 lbid. at para. 28.
} 
donor was not. The better position is that if the Supreme Court had intended this easily stated numerical limitation on the scope of the doctrine it would have said so.

It has been stated that there cannot be qualifying impossibility where the plaintiff's own conduct is the cause of the impossibility. ${ }^{309}$ That is a necessary implication of the requirement that "[t]he impossibility must be due to factors that are outside of the plaintiff's control; for example, current limits of scientific knowledge." ${ }^{310}$ It seems unlikely that there could be a situation where the impossibility has been caused (in a meaningful) sense by the plaintiff's conduct and will still be due to factors outside the plaintiff's control. However, does the problem causing the impossibility have to be something that, in some relevant sense, is the plaintiff's fault, too; that is, not just a result of the plaintiff's conduct? Rice $v$. Condran does not address this issue. The trial judge wrote, in summarizing his understanding of the Resurfice material contribution requirements: "[t]he other condition is that it must be impossible for the plaintiff to prove that the defendant caused the plaintiff's injury using the 'but for test and the plaintiff cannot be the cause of that impossibility." ${ }^{311}$ The trial judge did not explain the concluding proviso, nor cite any cases. There is nothing about the facts of Rice $v$. Condran case that provides context. The issue of the application of Resurfice material contribution did not arise. There might be cases where the fact the plaintiff dies in the incident, or otherwise before trial, that could satisfy the text of the Resurfice requirements. The fact that a plaintiff is dead and unable to provide required evidence can be described as a consequence of the current limits of scientific knowledge.

The problem of relating the cause of the lack of evidence to the conduct of the particular plaintiff, and the related question of whether that conduct has to be wrongful in some

\footnotetext{
309 Rice v. Condran, supra note 216; but see Bowes v. Edmonton, 2007 ABCA 347. In Rice v. Condran, ibid. at para. 40 , the trial judge wrote: "The other condition is that it must be impossible for the plaintiff to prove that the defendant caused the plaintiff's injury using the 'but for' test and the plaintiff cannot be the cause of that impossibility." The trial judge did not explain the statement, nor cite any cases. There is nothing about the case that provides context. It appears to be the trial judge's summary of the explanation in Resurfice.

310 Resurfice, supra note 1 at para. 25.

${ }^{311}$ Supra note 216.
} 
relevant sense, does not exist if the question is not what was or was not possible for the particular plaintiff but, rather, whether it was impossible for anyone to either prove or disprove factual causation on the balance of probability even if every bit of evidence that could ever be available to the moment of trial were put before the court. ${ }^{312}$

The impossibility requirement is not satisfied merely because the court concludes that the evidence does not establish that the negligence of a defendant is a but-for factual cause on the balance of probability, because the court prefers the defendant's evidence over the plaintiff's; ${ }^{313}$ or because the plaintiff failed to adduce evidence which could exist such as by not calling the necessary witness(es) ${ }^{314}$ or not asking witness(es) the necessary questions. ${ }^{315}$ The better explanation of what the Supreme Court meant by "impossibility ... due to factors that are outside of the plaintiff's control; for example, current limits of scientific knowledge" $\mathrm{e}^{316}$ is a problem of proof of factual causation caused by factors outside the plaintiff's control that amount to "intractable scientific uncertainty... wholly unconnected to the merits of the plaintiff's case." 317

Intractable scientific uncertainty seems to be a more useful description of the meaning of point of Resurfice's "current limits of scientific knowledge" proviso than phrases such as "truly impossible". ${ }^{318}$ "Intractable" defines the problem as one for which there is, currently, no valid scientific solution. Intractable scientific uncertainty seems to be a better description

\footnotetext{
312 See the text accompanying notes 248-252.

313 Seatle v. Purvis, supra note 177; Jackson v. Kelowna General Hospital, supra note 178.

314 B.S.A. Investors Ltd. v. DSB, supra note 176; Jackson v. Kelowna General Hospital, supra note 178; Barker v Montfort Hospital, supra note 112.

315 Barker v Montfort Hospital, ibid.

316 Resurfice, supra note 1 at para. 25.

317 Collins, "Causation, contribution and Clements", supra note 191 at 89.

318 Jackson v. Kelowna General Hospital, supra note 178, 2007 BCCA 129 at para. 22: "where it is truly impossible to say what caused the injury, such as where two tortious sources caused the injury ... or it is impossible to prove what a particular person in the chain of causation would have done in the absence of the negligence."
} 
of a class of problems of proof that are "logical or structural difficulties" and not merely "practical difficulties in establishing that the negligent act was a part of the causal chain". This interpretation meshes with tort law's position that probability in tort is a lower standard of certainty than probability in science. ${ }^{319}$ Whatever it is that creates valid intractable scientific uncertainty may create sufficient evidential uncertainty that even tort law's lower standard of certainty - the balance of probability - is not satisfied in some cases. It is essential to remember that, in most cases, intractable scientific uncertainty means only that science cannot provide an answer that factual causation is or is not probable by reference to that science's higher threshold of certainty. If the intractable scientific uncertainty is over the question of whether the negligence could have been a possible cause, the Resurfice material contribution doctrine cannot save the plaintiff. The action must fail on causation grounds. Resurfice material contribution cannot be interpreted to relieve a plaintiff of the obligation to establish general causation - the possibility the negligence could be a factual cause - on the balance of probability. ${ }^{320}$

The "intractable scientific uncertainty" description seems consistent with the Clements assertion that "'[c]urrent limits of scientific knowledge' should not be read ... to mean that the material contribution test is appropriate in any case where the science involved is difficult, complex, or "just not there yet"" 321 because "[w] hat is provable today may not have been provable last year; what cannot be proven today may be provable next year. That forensic science is not always able to provide an answer to a causation question is not a reason for doing away with causation as an essential element of a plaintiff's case." ${ }^{322}$ There

\footnotetext{
${ }^{319}$ Snell, supra note 42 at 328: "causation need not be determined with scientific precision"; and at 330: "Medical experts ordinarily determine causation in terms of certainties whereas a lesser standard is demanded by the law." The result is that tort law allows a "probably" conclusion in some circumstances where probability is not a valid scientific conclusion. This should be limited to cases where science does not exclude the conclusion that a causal connection exists. See Barry Edward McDonald v. Girkaid Pty Ltd., [2004] NSWCA 297 at para. 110.

${ }^{320}$ Supra note 4.

321 Clements, supra note 146, 2010 BCCA 581 at para. 59, quoting and adopting the explanation in Knutsen, "Clarifying Causation", supra note 200 at 171.

322 lbid. at para. 59.
} 
could be intractable scientific uncertainty where the reason that sufficient evidence is not available for the judge or jury to make a valid decision on the balance of probability is not due to "the default of the defendant but from the limited level of development in a given discipline." 323 It involves "an evidentiary vacuum of some kind. It is not merely that the plaintiff cannot prove the salient causal question, but rather that the matter is ... incapable of proof" ${ }^{\prime 324}$ under the current limits of scientific knowledge. ${ }^{325}$ The required level of scientific uncertainty may exist where there is inadequate medical knowledge of the aetiology of a disease. ${ }^{326}$

The concept of intractable scientific uncertainty may turn out to be helpful but will require careful development to avoid it becoming nothing more than a restatement of the "current limits of scientific knowledge" proviso. It may be that the only reason the problem is considered "intractable" is the current limits of scientific knowledge. That does not mean it will necessarily be intractable tomorrow. This is another reason for the fairness and justice limitation. The Aristorenas statement about the meaning of Athey's "unworkable" - that the Athey version of material contribution test was "invoked because of logical or structural difficulties in establishing 'but for' causation, not because of practical difficulties in

\footnotetext{
323 Collins, "Causation, contribution and Clements", supra note 191 at 87 . At 89, Collins compares accidents involving canoes against accidents involving motor vehicles to explain the meaning of phrase, arguing that, because motor vehicles are "a relatively new invention in human history" there is "significant uncertainty ... regarding their dynamics" when compared to canoes. Collins argues that this "significant uncertainty" meant there was "no acceptable methodology for answering the causal question on a 'but for' standard", thus justifying resort to the Resurfice material contribution to risk standard.

324 Ibid. at 89 [internal quotation marks omitted].

325 That is the basis of the United Kingdom's version of a material contribution to risk test. See Fairchild supra note 89 and Sienkiewicz, supra note 99, [2011] UKSC 10 at para. 18-19. See Klar, Tort Law, supra note 25 at 443-45 for a succinct summary.

326

For example, mesothelioma caused by inhalation of asbestos fibres: Fairchild supra note 89 and Sienkiewicz, supra note 99. See also Jane Stapleton, "Lords a'leaping evidentiary gaps" (2002) 10 Torts L.J. 276 at 5-6 ("The evidentiary gap in Fairchild existed because the mechanism by which asbestos fibre precipitates mesothelioma is unknown."); and Klar, Tort Law, supra note 25 at 443 at the text accompanying n. 72: "What was not provable, however, due to inadequate medical knowledge, was which exposure or exposures triggered the mesothelioma. ... Thus, on the facts of this type of case, it was impossible to say with any degree of probability where the employees contracted the disease."
} 
establishing that the negligent act was a part of the causal chain" ${ }^{327}$ - has the same flaws. "Logical or structural" seems to be a restatement of "intractable scientific uncertainty". All of these versions have no limits other than arbitrary limits.

Where the asserted basis of qualifying impossibility is current limits of scientific knowledge, the valid use of Resurfice material contribution must be understood to require expert evidence, accepted by the judge or jury, that proof of factual causation on the balance of probability is currently beyond the limits of the applicable science using that science's methodologies. Whether a "yes" or "no" answer to the probability question is validly obtainable under that science's methodology is necessarily a matter of expert opinion. Therefore, where the proposed basis for qualifying impossibility is current limits of scientific knowledge, it should not be open to a judge or jury to make that finding in the absence of expert evidence that it is beyond the current limits. This also means that it should not be open to a judge or jury to reject expert evidence that the negligence was not a probable cause of the injury, and then hold that the correct answer to the probability question is beyond the current limits of scientific knowledge based on "common sense" or any other form of call to the innate understanding of factual causation that sensible people are supposed to have. ${ }^{328}$

\footnotetext{
327 Aristorenas, supra note 92 at para. 53. 328

As happened in Clements, supra note 146, where the trial judge rejected the defence's expert evidence that the defendant's negligence was not a cause of the accident and then used "ordinary common sense" to conclude that there was "a relationship" between the negligence and the accident. See 2009 BCSC 112 at paras. 62-65. Some of the questions the Supreme Court put to counsel during the hearing of the Clements' dealt with the ability of a judge or jury to decide the current limit of scientific knowledge issue without expert evidence, particularly where there was contrary expert evidence which the judge or jury validly rejects. The webcast of the hearing is located at http://www.scc-csc.gc.ca/case-dossier/cms-sgd/webcast-webdiffusion-eng.aspx?cas $=34100$. The basis upon which judges and juries are entitled to reject admissible but uncontradicted expert evidence and make conclusions contrary to that evidence, or make conclusions that go beyond what the expert was prepared to make which are conclusions for which expert evidence is required, invokes issues of evidence law which beyond the scope of this paper.
} 
To date, Clements ${ }^{329}$ is the only decision that attempts to analyze the "current limits of scientific knowledge" proviso. Clements holds that the mere fact the current limits of scientific knowledge produce the consequence that the plaintiff is not able to establish that the defendant's negligence was a factual cause, on the balance of probability, is not enough to satisfy the requirements of Resurfice material contribution. ${ }^{330}$ Clements holds that plaintiff must show that it would be unjust and unfair to dismiss the action merely because the plaintiff has been unable to establish factual causation on the balance of probability. ${ }^{331}$ Clements does not set out the standard of proof for qualifying scientific impossibility. It has to be the balance of probability. ${ }^{332}$

Clements holds that the Resurfice material contribution test is "reserved for rare cases involving logical impossibilities". ${ }^{333}$ Clements also asserts that the but-for test "rarely fails, and currently only in situations involving circular causation and dependency causation". ${ }^{334}$ Clements accepts the proposition that "[c]ircular causation involves factual situations where it is impossible for the plaintiff to prove which one of two or more possible tortious causes are the cause of the plaintiff's harm" ${ }^{335}$ Clements is not a case of too many causal candidates. The plaintiff's apparent problem was that she seemed to not have the evidence required to establish the causal connection on the balance of probability. Her counsel might

${ }^{329}$ Supra note 146. The approach of the prior cases is captured in the laconic explanation provided by the British Columbia Court of Appeal in Jackson v. Kelowna General Hospital, supra note 178 at para. 22: impossible means "truly impossible" as shown by the examples provided in Resurfice.

${ }^{330}$ See the quotation from Clements at note 322 , above.

331 Ibid. at para. 64. See Chapter 3.2.4.

332 McDougall, supra note 154.

333 Clements, supra note 146, 2010 BCCA 581 at para. 58.

334 Ibid. at para. 63 applying Knutsen, "Clarifying Causation", supra note 200 at 163-64, 187-88. "Dependency causation" is discussed infra, Chapter 3.2.2.2. "Dependency causation" is not used, here, to mean but-for causation but to refer to a situation where the factual causation decision in some way depends on evidence that is, supposedly, not available to the judge or jury or inferences that cannot be validly made on the admissible evidence.

335 Ibid. [emphasis in original]. "Tortious" should not be in the definition for the definition to make sense. The circularity (of reasoning) is caused by the presence of multiple alternative causes. 
have thought that was the case because the plaintiff did not call expert evidence that there was a probable connection. ${ }^{336}$ In the result, Clements does not provide an explanation of the meaning of "the current limits of scientific knowledge" proviso. A statement that the proviso does not mean " $X$ " is not an explanation of what it does mean.

Ediger v. Johnston ${ }^{337}$ is a medical malpractice action in which the plaintiff alleged both lack of informed consent to the medical procedure and negligence in the performance of the procedure. The plaintiff succeeded at trial on both causes of action. The trial judge applied the but-for test. ${ }^{338}$ The trial judge declined to discuss the meaning of Resurfice material contribution. ${ }^{339}$ The British Court of Appeal allowed the defendant's appeal. The court held that the plaintiff had failed to establish factual causation for both causes of action because there was no evidence that permitted the judge to decide, validly, that the defendant's negligence was a cause of the injury. ${ }^{340}$ The court held that the Resurfice material contribution test was not applicable because it was not impossible for the plaintiff to have proved that the physician's negligence caused the injury by adducing the required evidence. ${ }^{341}$ Ediger formally accepts the explanation of Resurfice material contribution set out in Sam v. Wilson. ${ }^{342}$ Ediger does not mention Clements. Ediger describes the problem to which the impossibility requirement applies in a way that seems inconsistent with both Resurfice and Clements. Ediger states the impossibility requirement described in Resurfice applies to "those situations where it is impossible to determine which of the negligent acts

\footnotetext{
336 Also, if one takes the trial reasons at face value, the plaintiff did not strenuously argue, on the basis of Snell, that the evidence was nonetheless sufficient to satisfy the but-for test on the balance of probability.

337 Ediger v. Johnston, 2011 BCCA 253, reversing 2009 BCSC 386; leave to appeal granted 2012 CanLII 8362 (S.C.C.) (SCC case number 34408) [Ediger]. None of the three judges on the Ediger panel sat on the Clements panel. 
of two or more defendants created an unreasonable risk of the type of injury that the plaintiff experienced". ${ }^{343}$ That statement is not an accurate paraphrase of the impossibility requirement or either example. It is also a misstatement of negligence law. A person can be negligent only if the person's conduct creates an unreasonable risk of injury. If it is impossible to determine if somebody's conduct created an unreasonable risk, then it is it not possible to find that person negligent. ${ }^{344}$ The problem that the impossibility requirement describes is the problem of determining whether the conduct that created the unreasonable risk caused the injury, not whether a defendant's conduct created unreasonable risk.

Imagine a case where the evidence the plaintiff needs exists in another country but there are valid reasons why the plaintiff cannot get that evidence to court. Imagine, too, that the reason why a problem exists which is outside the plaintiff's control is not related, in any way, to the plaintiff's conduct or the defendant's negligent conduct. In B.S.A. Investors Ltd. v. $D S B,{ }^{345}$ there was no suggestion that the missing witness could not have been called. He just was not, without explanation. In that sense the missing evidence was related to the plaintiff's conduct, since the plaintiff had the onus of proof and the risk of non-persuasion. It should not offend basic notions of justice and fairness that the plaintiff's action was dismissed. ${ }^{346}$

But what if the evidence could have been obtained but no longer can be, by anybody? For example, imagine a situation where a witness is dead and the deceased's evidence was not obtained, before death, in a manner that would make the evidence admissible at trial. Or, what if the witness is out of the jurisdiction, is in a jurisdiction which will not co-operate by ordering the witness to attend to give his or her evidence in a deposition in that country, and the witness will not co-operate without a payment the plaintiff cannot afford? Or what if the

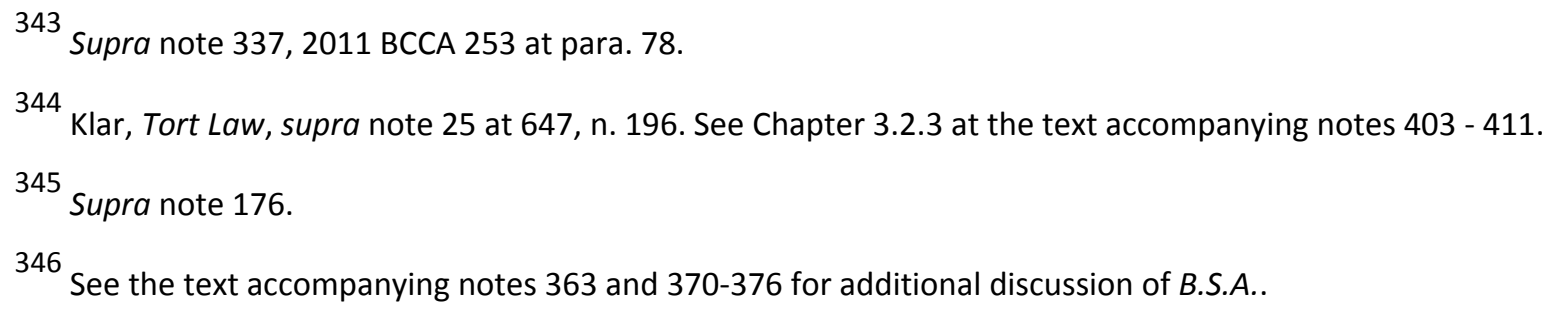


witness simply cannot be found? What if the evidence existed in Canada at one time but no longer exists and the reason the plaintiff does not have the evidence is that the plaintiff did not know that there was actionable injury (or even any injury at all) until after the evidence became unavailable? Can the plaintiff be criticized for not having evidence the plaintiff did not know of, and which became unavailable, even before the plaintiff knew or ought to have known the plaintiff had a cause of action? Do any of these circumstances create a qualifying instance where the evidence is not available because of factors outside the plaintiff's control ${ }^{347}$ All of these issues arise if Resurfice is understood to provide that the question is whether the factors are outside the actual plaintiff's control, not the hypothetical (objective) plaintiff with unlimited resources who does all that is required to prove the plaintiff's case. They do not (or at least need not) if the impossibility requirement is understood to mean "impossible for anyone to either prove or disprove even if every bit of evidence that could ever be available to the moment of trial were put before the court." ${ }^{348}$

The Resurfice impossibility requirement is capable of applying in all cases where there is a conclusion that the evidence would not be enough to allow a valid conclusion on the balance of probability, even if all of the evidence that current scientific knowledge is able to provide, together with all other evidence, is taken into account. Every case where we conclude there is not enough evidence to permit a valid conclusion, on the balance of probability, on one or both of "who did it" or "what was the cause", using whatever methods are valid for that purpose, is a case which can be described as one where the lack of evidence is due to "current limits of scientific knowledge" or due "intractable scientific uncertainty". This is because we lack, currently, the ability to recreate exactly all of the conditions that existed at the instant the injury occurred, and adequately identify each and every one of the relevant conditions. Computer programs can be written that attempt to reconstruct what happened. The answers provided by those programs are only as good as the data used and the

\footnotetext{
347 A majority of a panel of the Alberta Court of Appeal seemed to think so in Bowes v. Edmonton (City), supra note 309.

348 Black and Cheifetz, "Looking Glass”, supra note 227 at 249.
} 
assumptions made. At some point, the data and assumption move into the area of improper speculation. We lack the ability to go back into the past so as to adequately identify each and every one of the relevant conditions. If we could do that, we would know whether we have or do not have sufficient evidence to identify a cause on the balance of probability. It may or may not be fantasy beyond science fiction to speculate on whether we will ever have the necessary abilities. It is speculation that is not permissible for the law.

The Resurfice version of material contribution, unlike the United Kingdom's Fairchild version, is not restricted to a particular type of injury. The Fairchild version, for example, is, so far, limited to mesothelioma claims resulting from exposure to asbestos. ${ }^{349}$ Nonetheless, it has to be accepted that the Supreme Court did not intend the Resurfice material contribution test to be widely applicable. The Court described the circumstances to which the test applies as "special" 350 and "exceptional". ${ }^{351}$ However, there is nothing in the Resurfice statement of the impossibility requirement that identifies which instances that satisfy the requirement are exceptional or special and which instances are not. Clements attempted to answer this question by resorting to the "basic notions of fairness and justice" dictum in Resurfice would it "offend basic notions of fairness and justice to deny liability by applying a 'but for' approach" ${ }^{352}$ - as an overriding, normative, control on the circumstances capable of satisfying the impossibility. ${ }^{353}$ If the "basic notions of fairness and justice" dictum is not some sort of control, ${ }^{354}$ there is nothing in Resurfice, itself, that provides the courts with any

349 The House of Lords refused to extend Fairchild material contribution to medical negligence in Gregg v. Scott, [2005] 2 A.C. 176, [2005] UKHL 2.

350 Resurfice, supra note 1 at para. 24.

351 lbid. at para. 25.

352 Supra note 146 at para. 64.

353 Supra note 99, 2010 BCCA 581 at 64. See Chapter 3.2.4.

354 The dictum is discussed in Chapter 3.2.4. 
guidance as to which instances of evidential impossibility qualify and which do not. The second requirement - the "ambit of risk" condition - is not a useful control. ${ }^{355}$

\subsubsection{Decision Causation or Dependency Causation}

Resurfice's second example of an instance that may create relevant impossibility preventing the valid use of the but-for test to prove or disprove factual causation, on the balance of probability, is "where it is impossible to prove what a particular person in the causal chain would have done had the defendant not committed a negligent act or omission, thus breaking the "but for' chain of causation." ${ }^{356}$ The second example in seems to be premised on the assumption that there is something unique about the causation issue where the question is not what the plaintiff would have done but what some other person would have done had the defendant not been negligent, where that other person's conduct is or may be relevant to the conclusion as to whether the defendant's negligence was a factual and legal cause of the plaintiff's injury.

The Supreme Court did not explain why, in principle, the problem of deciding, on an objective basis, what a third person involved in the causal chain would have done is any more difficult than the problem of deciding, on an objective basis, what a plaintiff would or would not have done if the defendant had not been negligent. The latter problem is what judges and juries are required to do in many actions. "The but-for test of causation has traditionally been applicable even in cases where the hypothetical question requires prediction of human reaction." ${ }^{\prime 357}$ This includes actions where the claim is based on lack of informed consent for medical treatment; ${ }^{358}$ claims based on negligent misrepresentation; actions where a defendant alleges that a plaintiff's conduct after the defendant's is contributory fault; or where a defendant alleges the plaintiff failed to mitigate. A possible

\footnotetext{
355 The ambit of risk condition is discussed in Chapter 3.2.3.

356 Resurfice, supra note 1, para. 28. The text of para. 28 is quoted at note 275.

357 See the authorities cited supra in notes 280-281.

358 Reibl v. Hughes, supra note 276, Picard and Robertson, Legal Liability of Doctors, supra note 276.
} 
reason for different treatment is that, in most cases, there is evidence from a living plaintiff; or, where the plaintiff is a legal person such as a corporation, from people representing the corporation. However, that is not always the case. People have been known to die before trial, sometimes even before their version of what happened can be preserved in a manner that makes it admissible at trial. ${ }^{359}$

The second example, as written, describes two distinct issues. Only one is a factual causation issue. That is the impossibility of proof of factual causation on the balance of probability problem. The second is a remoteness (proximate cause) problem. The concept of conduct "breaking the chain" of factual causation is not a factual causation issue. To describe a factual causation issue, the first sentence of the second example has to be understood to mean: 'breaking' the ability of the plaintiff to establish the but-for chain of causation on the balance of probability because of some problem of proof arising out of the involvement of the third person. Remoteness issues arise only where that factual causation has been established on the balance of probability. The factual chain of causation is not broken when a remoteness defence applies. Remoteness is an extent of liability issue. Klar, Tort Law, summarizes: "Remoteness questions deal with how far liability should extend in reference to injuries caused to the plaintiff, once a duty relationship and negligent behaviour have been established." ${ }^{360}$ One of the circumstances that may provide a defendant with a remoteness defence is the conduct of a person other than the plaintiff. In some circumstances, that conduct will provide a defendant with a defence that the defendant's negligent conduct is not an actionable legal cause even though it is a factual cause. ${ }^{361}$

\footnotetext{
359 Canadian common law jurisdictions have common law and statutory rules governing these situations. See, for example, Rule 36 of the Ontario Rules of Civil Procedure, R.R.O. 1990, Reg. 194 (obtaining of evidence of witness before trial where there is the possibility the witness will not be available to testify for various reasons including death). There are also exceptions to the hearsay rule which might apply. See Sopinka, Lederman \& Bryant, The Law of Evidence in Canada, 3rd ed. by Alan W. Bryant, Sidney N. Lederman and Michelle K. Fuerst (Markham, Ont.: LexisNexis, 2009) at $\S 6.156$ - $§ 6.184$ (dying declaration exception to the hearsay rule).

360 Klar, Tort Law, supra note 25 at 467.

${ }^{361}$ See generally Klar, Tort Law, ibid. at 491-504, under the "novus actus interveniens" heading.
} 
In Walker Estate, where the "other person" testified, his evidence as to what he would have done was found to be sufficient for a but-for finding that had the defendant provided proper advice as to whether he qualified to give blood, he would not have donated blood. ${ }^{362}$ However, it is not the case that the failure of the other person to testify necessarily means that the court will not have the evidence required to make a valid conclusion on the balance of probability. ${ }^{363}$ Resurfice used the facts of Walker Estate without describing what it was about Walker Estate that would have created qualifying impossibility had it been the case that the evidence did not exist to allow a valid finding of factual causation on the balance of probability. The statement that "once again, the impossibility of establishing causation and the element of injury-related risk created by the defendant are central" ${ }^{364}$ does not explain what factor or factors will move the case into the exceptional category where the action is not to be dismissed merely because of the plaintiff's failure to establish factual causation on the balance of probability.

The grammatical meaning of the text of the second example could include the plaintiff as a person whose conduct has to be considered in determining whether it is impossible to validly apply the but-for test to the negligent conduct of a defendant. ${ }^{365}$ Judges paraphrasing the example treat it as referring to the conduct of some person other than the plaintiff. However, Clements might not have. The British Columbia Court of Appeal stated that the facts of Clements did not fit the second example because the factual causation issue upon which the defendant's liability turned did not depend on deciding what one party would

\footnotetext{
362 Supra note 21 at para. 97.

${ }^{363}$ See B.S.A. Investors Ltd. v. DSB., supra note 176. B.S.A. is discussed infra at notes 370-376.

364 Resurfice, supra note 1 at para. 28

365 This is, historically, what judges and juries did when applying the arcane distinctions that the common law developed to avoid the consequences of the common rule that the plaintiff's contributory negligence was a complete defence. If the plaintiff's conduct was not considered causal, then it could not be contributory negligence. If it was not causal, then it could not "break" the causal connection between the defendant's conduct and the injury.
} 
have done if another party had not been negligent. ${ }^{366}$ While Clements did not use "party" in the technical sense of a person who is a litigant, the context precludes the conclusion that the British Columbia Court of Appeal intended to mean only the wrongdoers and persons other than the injured person. ${ }^{367}$ Nonetheless, the better interpretation of the second example is that the "particular person in the causal" chain referred to in the second example is not the plaintiff. ${ }^{368}$ One reason is that Walker Estate involved the question of what someone other than the plaintiff would have done. The better reason, though, is the point made earlier. ${ }^{369}$ Judges and juries, historically, have not found it impossible to make valid, for legal purposes, conclusions about factual causation on the balance of probability even where that conclusion required prediction of human reaction where this was the plaintiff's reaction.

The British Columbia Court of Appeal considered the application of the second example in B.S.A. Investors $L t d$. v. DSB. ${ }^{370} \mathrm{M}$ defrauded the plaintiff of $\$ 550,000$. The allegation against the defendant $D S B$ was that the fraud would not have succeeded but-for the negligence of DSB. DSB's negligence was in failing to require $M$ to obtain a second signature on the document that $\mathrm{M}$ used to carry out the fraud. The plaintiff's evidence was that the person to whom $\mathrm{M}$ would have had to go to get that signature would not have signed. ${ }^{371}$ The trial was in 2004. M did not testify so there was no direct evidence as to what M probably have done in that case; that is, his evidence on what he would have done if required to obtain the second signature. Nonetheless, the plaintiff succeeded. The defendant appealed. The appeal

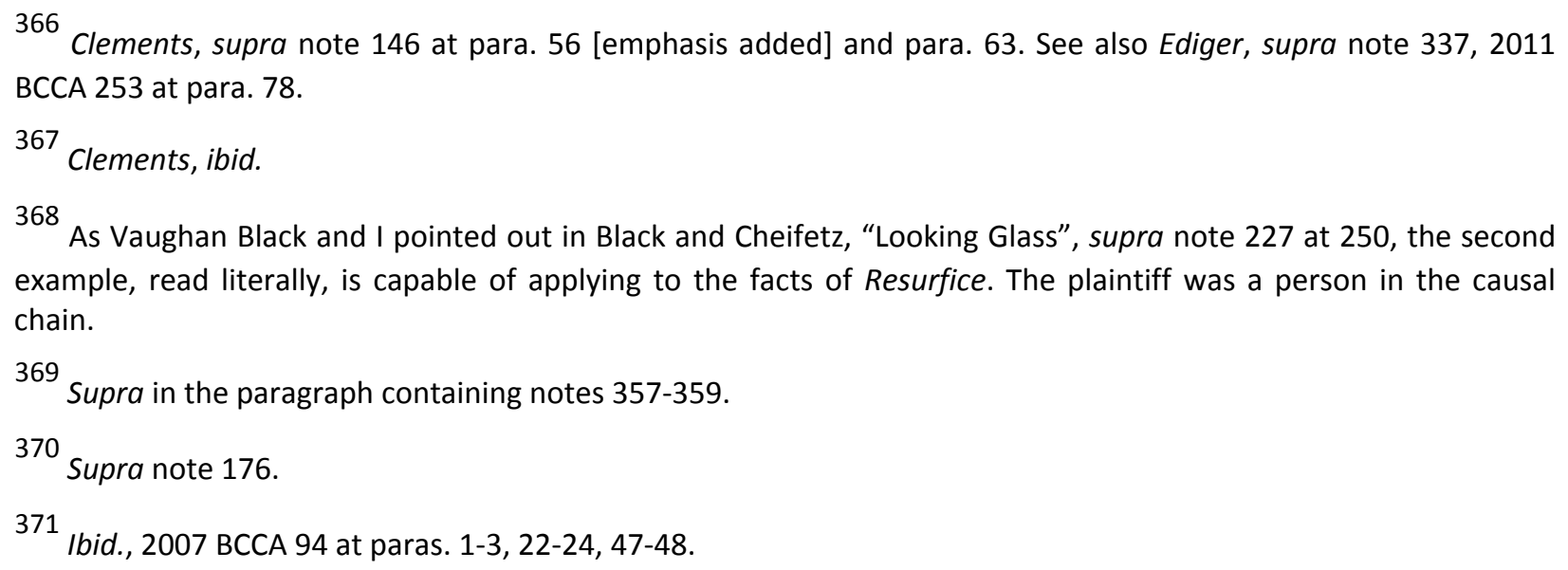


was argued in 2006, before Resurfice. The appeal reasons were released in May, 2007, after Resurfice. The appeal was allowed. The action was dismissed. ${ }^{372}$ The Court of Appeal held that the plaintiff had failed to establish, on the balance of probability, that the defendant's negligence was a cause of the loss. Referring, first, only to case law predating Resurfice, the Court of Appeal held that it was not open to the judge to conclude that factual causation had been proven on the balance of probability merely from the fact that the defendant's negligence increased the risk of the occurrence of the loss which occurred. ${ }^{373}$

The Court of Appeal then referred to Resurfice. ${ }^{374}$ The court held that the second example in Resurfice did not apply because, even without M's evidence, the case was one in which there could have been other evidence called sufficient to allow a valid decision to be made, on a but-for basis, as to what would or would not have probably occurred had the defendant not been negligent. Thus, it was not impossible to use the but-for test validly. ${ }^{375}$ It was the plaintiff's obligation, under the but-for test, to show, on a balance of probability, that had the defendant fulfilled its duty, M probably "would have been stopped". ${ }^{376}$ The plaintiff had not met that burden. As such, the court did not consider what law would have governed, and what the result would have been under that law, had the court concluded that direct evidence from $\mathrm{M}$ was necessary for a valid conclusion using the but-for test.

\footnotetext{
372 Ibid. at para. 50.
}

373

Ibid. at paras. $32-43$, especially para. 43 . The court held that the trial judge had found the plaintiff had failed to establish, on the balance of probability, that the fraud would not have occurred if the defendants had not been negligent: Ibid. at para. 25. The court also held the trial judge had found that the defendants had failed to establish, on the balance of probability, that the fraud would have occurred even the defendants not been negligent; that is, that it would have occurred even if they had acted properly: Ibid. at paras. 23-24. Paras. 23 and 24 quote the relevant portion of the trial reasons. The better view of the trial judge's reasons is that he did not find for the plaintiff notwithstanding that he had held the plaintiff had failed to establish factual causation on the balance of probability. Rather, he held the fact that, in the circumstances, the defendant's negligence materially increased the risk of the occurrence of the very loss that occurred, together with other evidence, was sufficient to infer that the defendant's negligence was a probable cause. The trial judge relied on Snell and Haag v. Marshall (1989), 61 D.L.R. (4th) 371, 1989 CanLII 236 (B.C. C.A.). See 2007 BCCA 94 at para. 24 quoting the relevant portions of the trial reasons.

374 Ibid. at para. 44. The Court of Appeal quoted paras. 20-28 of Resurfice.

375 Ibid. at para. $45-48$.

376 Ibid., para. 48. 
Clements describes the second example as one of "dependency" causation, adopting the label from Knutsen, "Clarifying Causation". ${ }^{377}$ Erik Knutsen wrote:

The causal link between the at-fault defendant and the injured plaintiff is thus mediated by the action of a third party. This 'dependency causation' necessarily relies on evidence of causation beyond the relationship between the at-fault defendant and the injured plaintiff, and is potentially very difficult to obtain. ${ }^{378}$

However, it is often the case in litigation that correct answer to the factual causation question requires evidence "beyond the relationship between the at-fault defendant and the ... plaintiff." ${ }^{379}$ In principle, the fact that a plaintiff may have to go "beyond that relationship", however one defines what it means to go "beyond that relationship", is nothing more than what Aristorenas described as "practical difficulties in establishing that the negligent act was a part of the causal chain." 380 That, as Aristorenas held, is not grounds for applying some test other than the but-for test. Another problem is apparent from Knutsen's description. "[P]otentially very difficult" is not impossible. Resurfice says "impossible".

There is a better way of describing the problem of proof of factual causation on the balance of probability that the Supreme Court attempted to describe in the second example. It is known as the problem of "decision causation". Vaughan Black wrote, before Resurfice, that there is a

cluster of claims made in some judicial opinions and academic writing to the effect that counterfactual inquiries involving judgments about hypothetical decisions are unique, or at least are distinct from those inquiries which do not - so much so that they require special rules which operate as exceptions to the usual standard for factual causation. This is the problem of decision causation.

...

... [B]y 'decision causation' we mean the problem that arises when the speculation involved in the counterfactual inquiry into what would have happened had the

377

Ibid. at para. 54; Knutsen ,“Clarifying Causation”, supra note 6 at 164, 187.

378

Knutsen, "Clarifying Causation", supra note 200 at 164.

379 Knutsen's statement may true, in practice, for many personal injury actions. It is also is true that, currently, developments in tort law tend to come from varieties of personal injury action. Neither point is of any relevance.

380 Aristorenas, supra note 92 at para. 53. 
defendant not violated the plaintiff's rights brings up an inquiry into what some later decision would have been. ${ }^{381}$

The point of the second example is not just that the factual causation decision may require some consideration of the effect of a third person's conduct. It is that the factual causation may depend on a valid decision as to what that other person would have decided to do had the defendant acted properly.

Resurfice asserts, without explanation, that there may be relevant impossibility in instances requiring decision causation. Black states that there seems to be "two distinct claims about the way in which decision causation differs from regular causation." ${ }^{382}$ One claim is that the two are "discrete phenomena", and the differences are such that decision causation requires a different analysis. ${ }^{383}$ The rationale for this view appears to be the claim that, where the but-for test is used, the counterfactual inquiry involved in instances of decision causation is of a "non-scientific nature" because it involves considering the consequences of the interposition of a person's "will ... between the defendant's conduct and the subsequent damage". ${ }^{384}$ The "will" referred to in the source of the preceding quotation was the injured person's "will" and not a third person's will. The other claim that there is something unique about decision causation does not assert it is "different in type from other counterfactual inquiries, but asserts only that we have less reason to be confident of our judgments about decision causation ... relying on the assertion that people are capricious and unknowable,

\footnotetext{
381 Vaughan Black "Decision Causation: Pandora's Tool-Box" in Jason Neyers, Erika Chamberlain, and Stephen Pitel, eds., Emerging Issues in Tort Law (Oxford: Hart Publishing, 2007) 309 at 311 [Black, "Decision Causation"]. The paper was first presented at a conference at the University of Western Ontario Faculty of Law in the summer of 2006.

382 Ibid. at 311.

383 Ibid. at 311-12.

384

Ibid. at 311-12 quoting from Denis Boivin, "Factual Causation in the Law of Manufacturer Failure to Warn" (1998), 30 Ottawa L. Rev. 47 at 51, 69. Black cites other articles asserting the validity of this distinction: ibid. at 312, n. 15 and accompanying text.
} 
and that decisions they might make are unpredictable." ${ }^{385}$ It is not without irony that the case that Black discusses, as an example of the second claim, is Walker Estate. ${ }^{386}$

Black notes that while the two claims offer separate rationales for the assertion that there is something sufficiently different about decision causation to require a different analysis, at their core they share the same premise. It is that

requiring judges or juries to speculate about what decision some person would have made in some hypothetical situation requires them to undertake a particularly dicey exercise, one in whose answer we could have little reason to have confidence and which - in the more radical versions of the claims - should be regarded as virtually non-justiciable. ${ }^{387}$

Black asserts that the validity of the claim that instances that require decision causation are sufficiently different from instances that do not so as to require a different analysis, in principle, has not been adequately established, while conceding that there might be instances where a different approach is warranted.

If claims about the unicity of decision causation rest entirely on the relative reliability of our speculations about hypothetical choices, as opposed to speculations about hypotheticals that do not involve choices, then we should be wary of them; it is far from clear that the special rules that rest on such claims stand on sound ground. There are explanations for why we might be psychologically disposed to treat decisions, including hypothetical ones, as singular, exceptional phenomena, but it is far from obvious that we are any worse at predicting the outcomes of decisions than we are at predicting the ordinary, non-decision outcomes. However ... [the] same explanations for why we might be inclined to see some classes of decisions as distinctive might both explain why judges have so often been inclined to treat them as exceptional and, more importantly, point the way to a more refined justification for why we might, at least on occasion, be right to do so. ${ }^{388}$

Black's scepticism exists judicially. ${ }^{389}$ As both Walker Estate ${ }^{390}$ and B.S.A. Investors Ltd. v. $D S B^{391}$ show, the supposed problem of decision causation is not necessarily one that prevents the valid application of the but-for test.

385

Ibid. at 312.

386

Ibid. at 312-313.

387

Ibid. at 313.

388

Ibid. at 329-330 [word in brackets added].

${ }^{389}$ See supra notes 280 and 281. 
The mere fact that the causal link depends in some way on the conduct of another person is not the point. The judge or jury may still be able to decide the factual causation issue on the balance of probability either for or against the plaintiff. ${ }^{392}$ The question may be as simple as what that person did or did not do. It may or may not require asking that person what he or she would have done. There may sometimes be credibility issues whether or not the person testifies. There might be sufficient evidence, whether direct or circumstantial, even where this person does not testify. ${ }^{393}$ The issue is what factors are required to make the situation an exceptional case where the Resurfice material contribution doctrine applies if neither party is able to prove or disprove factual causation on the balance of probability. Resurfice does not help. As written, the second example in Resurfice is overbroad.

... [1]t does not fit the Supreme Court's goal of confining the material-contribution test to special circumstances. A large number of causal chains require speculation as to some hypothetical decision of a particular person. All claims for fraud and misrepresentation do, as do all cases of failure to warn (for instance by manufacturers and doctors), failure to provide safety equipment, and many others as well. Such cases are not exceptional, or at least not rare. ${ }^{394}$

The second example requires the judge or jury to distinguish between cases where the speculative component of the but-for counterfactual analysis can be validly made and those in which it cannot be. That line will not be easy to draw, even if it is plausible, and there appears to be a substantial risk that distinctions will be based on expediency, not principle. $^{395}$

390

Supra note 21.

391 Supra note 176.

392 See, for example, B.S.A. Investors Ltd. v. DSB, supra note 176. See also Jackson v. Kelowna General Hospital, supra note 178; Barker v Montfort Hospital, supra note 112; Walker Estate, supra note 21.

393

For example, B.S.A. Investors Ltd. v. DSB, supra note 176.

394 Black and Cheifetz, "Looking Glass", supra note 227 at 250. See also Vaughan Black, "Decision Causation", supra note 381.

395 See Black and Cheifetz, "Looking Glass", supra note 227 at 255. This paragraph paraphrases our summary. 


\subsubsection{Conclusion}

Each of the two examples offered in Resurfice has to be understood as an example of instances to which the Resurfice material contribution might be applicable, not instances where it is necessarily applicable. The first example is the assumed facts of Cook v. Lewis. ${ }^{396}$ Unless the Supreme Court intended to overrule Cook v. Lewis, but somehow forget to mention that, those facts, should they occur again, or should legally equivalent facts occur, do not require Resurfice material contribution for the plaintiff to succeed. The rule in Cook $v$. Lewis will apply and the plaintiff will succeed against at least one of the two tortfeasors, perhaps both (so long as both are sued). ${ }^{397}$ Thus, at least in those instances, there will have to be something more about the case that requires the application of the Resurfice material contribution. That something else could exist where the evidence is not sufficient to allow the plaintiff to prove, on the balance of probability, that the cause must be a set of factors that includes one or the other of the two tortious alternatives, so as to trigger the application of Cook v. Lewis. ${ }^{398}$ Other than there being more than two tortious alternatives, it is not clear what else could be required to take the case out of the ambit of the rule in Cook v. Lewis, so long as Cook v. Lewis remains good law. ${ }^{399}$

A similar problem does not exist in the same sense for the second example. It is the facts of Walker Estate. ${ }^{400}$ There is already a factual causation test for claims that create the problem of proof of factual causation on the balance of probability described in the second example: the sufficient condition version of a material contribution to injury test established in Walker Estate. ${ }^{401}$ However, the Walker Estate version of a material contribution test is limited to

396 Supra note 41.

397 A plaintiff who gambles and sues only one of the two risks losing completely.

398 See supra at the text accompanying notes 269-271.

399 This problem does not exist if there are 3 or more tortfeasors because the rule in Cook v. Lewis can be applied validly only where there are only two tortfeasors.

400 Supra note 21.

401

Ibid. at paras. 87-88. See supra at the text accompanying notes 44-46. 
claims arising out arising out of the negligent screening of blood donors. The Resurfice use of the facts of Walker Estate has to be understood as an example for cases having the problem of what a third person would have done, such as existed in Walker Estate, that are not cases arising out of the negligent screening of blood donors.

\subsubsection{Ambit of Risk}

The second of the expressly-stated prerequisites of the Resurfice material contribution test is the ambit of risk requirement.

Second, it must be clear that the defendant breached a duty of care owed to the plaintiff, thereby exposing the plaintiff to an unreasonable risk of injury, and the plaintiff must have suffered that form of injury. In other words, the plaintiff's injury must fall within the ambit of the risk created by the defendant's breach. ${ }^{402}$

However, the creation of unreasonable risk is a characteristic of the cause of action in negligence. There cannot be negligence without the creation of unreasonable risk. The mere creation of risk is not negligence. The requirement that the injury fall within the ambit of the risk created by the defendant's negligence is a characteristic of all causes of action in negligence. If it does not the action fails. It is puzzling that the Supreme Court chose an essential characteristic of all negligence actions as one of the two expressly-stated requirements which supposedly separate the ordinary case from the exceptional case to which the Resurfice material contribution doctrine may apply.

A plaintiff who satisfies all of the requirements of a cause of action in negligence other than causation will necessarily satisfy the ambit of risk requirement. ${ }^{403} \mathrm{Klar}$, Tort Law, states: "[I]t is the fault principle that lies at the heart of tort law. It is only where the risk introduced is an "unreasonable" one that liability will flow." ${ }^{404}$ The Supreme Court stated in Odhavji Estate v. Woodhouse, that "[d]uty may ... be defined as an obligation, recognised by law, to take

\footnotetext{
${ }^{402}$ Resurfice, supra note 1 at para. 25 [emphasis added].

403 Black and Cheifetz, "Looking Glass”, supra note 227 at 247-48.

${ }^{404}$ Klar, Tort Law, supra note 25 at 647, n. 196.
} 
reasonable care to avoid conduct that entails an unreasonable risk of harm to others." 405 The Court stated in Mustapha v. Culligan of Canada Ltd. that "[a] defendant's conduct is negligent if it creates an unreasonable risk of harm". ${ }^{406}$ A trial never reaches the causation analysis stage if any of the requirements of a cause of action in negligence that have to be satisfied before the causation analysis is undertaken cannot be satisfied. ${ }^{407}$ For example, where there is no duty of care at all; ${ }^{408}$ or no duty of care in respect of the injury alleged by the plaintiff, whether that is because of the nature of the injury, ${ }^{409}$ or the identity of the plaintiff, ${ }^{410}$ or the manner in which the injury occurred; ${ }^{411}$ then the injury is not within the ambit of the risk created by the defendant's conduct, even if the conduct is negligent.

405

Odhavji Estate v. Woodhouse, [2003] 3 S.C.R. 263 at para. 45, 2003 SCC 69.

406

[2008] 2 S.C.R. 114 at para. 7, 2008 SCC 27.

407

The causation inquiry is not undertaken until after the duty of care, standard of care, and breach of standard inquiries. See the authorities cited in note 222. See Klar, Tort Law, supra note 25 at 161-62 for a useful list of the questions that must be asked and answered, in the plaintiff's favour, in a negligence action if the plaintiff is to succeed.

408

Childs v. Desormeaux, [2006] 1 S.C.R. 643, 2006 SCC 18 (social hosts of parties where alcohol is served do not owe a duty of care to public users of highways); Horsley v. MacLaren, , [1972] S.C.R. 441, 1971 CanLII 24 (no rescuer duty).

409

For example, economic loss caused by the defendant's negligence where the economic loss does not fall into any of the categories of compensable economic loss. See Brown, Pure Economic Loss, supra note 71.

${ }^{410}$ See Joly v. Pelletier, 1999 CarswellOnt 1587 (Ont. S.C.J.) in which the plaintiff's action for damages based on the allegation that the defendants were attempting to kill him, or otherwise interfere with his ability to live freely, because he was a "Martian" was dismissed on the grounds that, since he claimed to be a "Martian" and not a human being, he did not have standing to sue under the laws of Ontario. The court held that a "Martian" did not fall within the definition of a person who had standing to sue, in Ontario, because a Martian was neither a human being nor a legal person as defined in the governing Ontario law.

\section{1}

Because, however the injury occurs, that manner is unusual enough that it falls outside the rule that "[i]t is not necessary that one foresee the 'precise concatenation of events'; it is enough to fix liability if one can foresee in a general way the class or character of injury which occurred". See R. v. Côté, [1976] 1 S.C.R. 595 at 604, 1974 CanLII 31 and Overseas Tankship (U.K.) Ltd. v. Miller Steamship Co. Pty. (Wagon Mound No. 2, [1967] 1 A.C. 617, [1966] UKPC 10 (P.C.) See, for example, Mustapha v. Culligan, supra note 406 (where the plaintiff sustained psychiatric injury because he saw a dead fly and parts of dead fly in a sealed, glass, water bottle supplied to him by the defendant and, as a result, became concerned about what that meant for his and his family's health since they had drunk water from other bottles supplied by the defendant) and Nespolon v. Alford, (1998) 40 O.R. (3d) 355, 1998 CanLII 7127 (C.A.) (where the plaintiff was driving a vehicle when he unknowingly, innocently, ran over and killed a teenager who was lying on the roadway; developed psychiatric injury as result of realizing he had killed the boy; and sued, amongst others, the teenaged driver and passenger of a vehicle in which the deceased had been riding shortly before the accident and who had let (or compelled) the deceased exit the vehicle even though, it was 
In Ediger v. Johnston, ${ }^{412}$ the British Columbia Court of Appeal explained the "ambit of the risk" requirement in negligence actions. The court held that the injury that the plaintiff sustained, which was caused by the defendant's conduct in the sense that the particular injury would not have occurred as it did if the defendant had not acted as he did, was not caused by the aspect of the defendant's conduct that was negligent. The Court of Appeal's point was that the physician's non-negligent conduct was a factual cause of the injury in the sense that injury which occurred would not have occurred, when and as it did, if the physician had not performed the procedure. However, the risk that the physician failed to warn the patient about - thus the failure that made him negligent - was not the risk that manifested and caused the plaintiff's injury. ${ }^{413}$

The better view of every case since Resurfice in which the judges referred to the ambit of risk requirement is that the judges have treated the requirement as nothing more than the requirement that the defendant be held negligent. The trial reasons in Farrant v. Latkin are paradigmatic.

In the present case, the second requirement for applying the "material contribution" test is satisfied. That is, by striking the plaintiff's vehicle, the defendant exposed the plaintiff to an unreasonable risk of spinal injury, and the plaintiff has suffered an injury that falls within the ambit of that risk. Whether the "material contribution" test should be applied therefore turns on whether factors beyond the plaintiff's control make it impossible for the plaintiff to prove that "but for" the defendant's negligence, the plaintiff would not have suffered injury. ${ }^{414}$

If all of those facts had not been true, and the findings made, leading up to the causation inquiry, the action would never had reached the causation inquiry.

There is another curious aspect to the Resurfice ambit of risk requirement. It has been mentioned earlier in other contexts. The use of unreasonable increase in risk as a

\footnotetext{
alleged, they knew or ought to have known he was drunk enough that he might wander on to a roadway and into the way of traffic.)

412 Supra note 337, 2011 BCCA 235 at paras. 95-101.

413 Ibid. at para. 101.

414 Supra note 144, 2008 BCSC 234 at para. 93.
} 
justification for reducing the standard of proof of factual causation is contrary to the Supreme Court's prior decisions. The Court did not mention any of these decisions other than Snell and Athey, but did not acknowledge that even these decisions are contrary. The Court had expressly rejected the use of material contribution to the increased risk of injury as sufficient proof of factual causation in a series of cases, starting with Snell. ${ }^{415}$ The Court wrote in St. Jean v. Mercier:

The [Québec] Court of Appeal appropriately said that it is insufficient to show that the defendant created a risk of harm and that the harm subsequently occurred within the ambit of the risk created. To the extent that such a notion is a separate means of proof with a less stringent standard to satisfy, Snell ... and definitely Laferrière ... should have put an end to such attempts at circumventing the traditional rules of proof on the balance of probabilities. ${ }^{416}$

Instead, the Court implied there are no contrary decisions by asserting that the material contribution principles it was about to outline are "general principles that emerge from the cases". ${ }^{417}$

It might be suggested that that Resurfice material contribution is different because it does not rely just on unreasonable increase in risk to circumvent the orthodox requirement of proof of causation on the balance of probability. The argument would be that Resurfice adds the requirement that it be impossible, for qualifying reasons, to establish factual causation on the balance of probability under the orthodox rules. The addition is not significant. The reason the plaintiffs failed on factual causation, in at least some of the Court's prior cases where the increased risk doctrine was rejected, was that it was impossible for the plaintiff to establish factual causation on the balance of probability, under but-for or any other available method, for reasons that seem to be capable of satisfying Resurfice's first requirement. ${ }^{418}$ It

\footnotetext{
${ }^{415}$ See supra cases listed in note 121.

416 Supra note 121, [2002] 1 S.C.R. 491 at para. 116.

417 Resurfice, supra note 1 at para. 20.

418 Probably all of the cases other than Stewart v. Pettie, supra note 121 . The problems of proof in each of Laferrière v. Lawson, supra note 121 and St. Jean v. Mercier, supra note 121 would be instances where then current limits of medical scientific knowledge precluded a decision on the balance or probability because the limits meant there was necessarily insufficient evidence for a valid decision on the balance of probability. Each of Hollis $v$.
} 
was not merely because the plaintiff failed to adduce evidence that, if adduced and accepted, would have satisfied the burden of proof. That the Court did not refer to the cases in which the Resurfice material contribution principles are supposedly inchoate leaves it open to conclude the Court chose not to because it did not want to deal with its contrary decisions. $^{419}$

Nonetheless, to claim that the explicitly stated ambit of risk requirement is meaningless as one of the criteria determining when the exceptional Resurfice material contribution test should be used is problematic because the Supreme Court certainly thought it was, and intended it be, meaningful. The ambit of risk requirement would never play any part in the determination of whether the defendant's conduct had any form of causal connection to the plaintiff's injury. Thus, if the ambit of risk requirement is to have any role as one of the criteria identifying exceptional cases, it must be in relation to the fairness and justice requirement. It must be something that helps the judge decide, assuming the impossibility condition as been satisfied, whether it will offend basic notions of fairness and justice to deny liability because the plaintiff was unable to establish factual causation on the balance of probability. ${ }^{420}$ This is additional support for the position that there is a separate fairness and justice requirement. ${ }^{421}$

If this view of the ambit of risk requirement is correct, the candidates in the text of the requirement are the phrases "it must be clear that the defendant breached a duty of care owed to the plaintiff" and "thereby exposing the plaintiff to an unreasonable risk". ${ }^{422}$

Dow Corning, supra note 121, Arndt v. Smith, supra note 121, and Walker Estate, supra note 21, would be examples of the decision causation problem that is the core of the second example in Resurfice.

419 This is one way to understand paragraph 20 of Resurfice, supra note 1: "Much judicial and academic ink has been spilled over the proper test for causation in cases of negligence. It is neither necessary nor helpful to catalogue the various debates. It suffices at this juncture to simply assert the general principles that emerge from the cases."

420 It has to be the judge. This cannot be a question of fact alone. Law is involved. Fairness and justice entails policy questions, too. See Chapter 3.2.4.

421 See Chapter 3.2.4.

422 Emphasis added. 
However, as "unreasonable risk" is required for all instances of negligence, "unreasonable" does not help to distinguish the "ordinary" case from the exceptional case to which Resurfice material contribution might apply. Perhaps the Court's intention was to signal that the instances of negligence to which the Resurfice material contribution doctrine must somehow not be ordinary instances of negligence. For example, in the phrase "it must be clear that the defendant breached a duty of care owed to the plaintiff", 423 "clear" modifies "breach". But it is not clear how this can be significant. Negligence requires a breach of a standard of care proved on the balance of probability. Negligence does not require a "clear" breach of the standard of care proved on the balance of probability.

Under current jurisprudence, "clear" cannot be interpreted to mean that Resurfice material contribution requires a standard of proof higher than the balance of probability. This would be contrary to F.H. v. McDougall. ${ }^{424}$ To suggest that "clear breach" somehow signals a need for more cogent evidence of the breach than would be required in cases to which Resurfice material contribution does not apply is also contrary to F.H. v. McDougall. McDougall is explicit that "evidence must always be sufficiently clear, convincing and cogent to satisfy the balance of probabilities test. ... If a responsible judge finds for the plaintiff, it must be accepted that the evidence was sufficiently clear, convincing and cogent to that judge that the plaintiff satisfied the balance of probabilities test." ${ }^{425}$ The point is that the judge or jury decide if the defendant's conduct breached the standard of care. If the judge or jury concludes the evidence is not clear enough to allow a valid conclusion, on the balance of probability, that a breach of the standard of care occurred, the action fails. If the judge or jury concludes the evidence is clear enough to allow a valid conclusion, on the balance of probability, that the breach occurred, then there must be a finding that the breach occurred. Once a finding is made that the evidence supports the finding that there was a breach of the standard of care, any question about the "clarity" of the breach is meaningless. A scale of

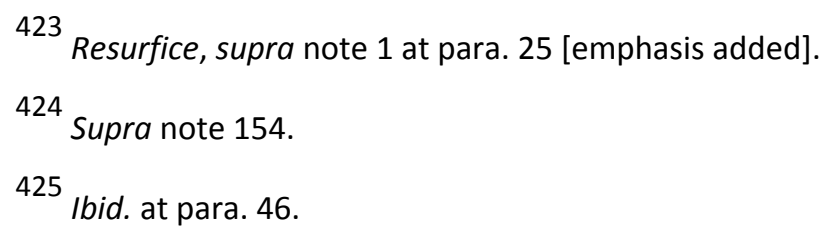


clarity by which a breach of the standard of care, established on the balance of probability is measured for eligibility for Resurfice material contribution has nothing to do with the requirements of the cause of action in negligence. It is difficult to see how such a scale could be anything other than arbitrary.

Nonetheless, since it is better to conclude the Supreme Court did not intend the ambit of risk requirement be meaningless as one of the criteria for identifying the exceptional instances to which Resurfice material contribution might apply, all that remains is to conclude this requirement is supposed to ensure there is something exceptional about the negligence aspect of the defendant's conduct, just as the impossibility requirement is intended to ensure there is something exceptional about the causation aspect. However, if this is what the Court meant, it seems to amount to a version of the attempt to distinguish between ordinary negligence and "gross" negligence. That distinction is impractical at best; implausible at worst. Klar, Tort Law, states: "It is clear that the phrase 'gross negligence' itself is not susceptible of a clear definition to assist courts in deciding whether it has been shown. It has frequently been defined in terms which merely replace the words 'gross negligence' with other equally ambiguous words, without clarifying the concept." ${ }^{426}$

If the purpose of the ambit of risk requirement is to limit the Resurfice material contribution doctrine to instances where there is something about the negligence that makes the case exceptional, then whatever line the Court intended will not be easy to draw, even if it is plausible. There is a substantial risk that distinctions will be based on more on expediency than principle. The ambit of risk requirement does not help to separate the exceptional instances to which the Resurfice material contribution test might apply from those to which it does not. The requirement "does nothing to advance [the Court's] advertised goal of

\footnotetext{
426 Supra note 25 at 361-62. See generally at 361-363. Klar's authorities include a 1925 Supreme Court of Canada decision stating "[t]he term 'gross negligence ... is not susceptible of definition." Klar, ibid. at 362, n. 164, citing Holland v. City of Toronto (1926), 59 O.L.R. 628 at 634, [1927] S.C.R. 242 (note).
} 
making the application of the material contribution test exceptional. In fact, it does nothing." 427

\subsubsection{Fairness and Justice}

\subsubsection{Introduction}

The issue considered in this section is whether the requirements of the Resurfice material contribution test are met when the plaintiff satisfies the impossibility and ambit of risk requirements or whether there is a third, overriding, fairness and justice requirement which much also be satisfied and, if so, the meaning of that requirement. The better position is that there is an overriding fairness and justice requirement. Quoting Clements, there is an "over-arching policy that the material-contribution test is available only when a denial of liability under the but-for test would offend basic notions of fairness and justice" ${ }^{428}$ Resurfice states:

In those exceptional cases where these two requirements are satisfied, liability may be imposed, even though the "but for" test is not satisfied, because it would offend basic notions of fairness and justice to deny liability by applying a "but for" approach. ${ }^{429}$

"Fairness" and "justice" are labels describing conclusions. What Resurfice does not do adequately is set out the facts that lead to those conclusions.

Having sketched the skeleton of material contribution doctrine which, on any valid reading of the text of Resurfice, is a change of some sort (even if intended to be nothing more than a clarification of existing doctrine), the Court owed a duty to the Canadian public to state clearly what it was the Court intended. It failed in Resurfice. Even if one accepts the need for a doctrine that permits the imposition of liability, in some exceptional cases, without proof of factual causation on the balance of probability, Resurfice does not explain adequately how

\footnotetext{
427 Black and Cheifetz, “Looking Glass”, supra note 227 at 248.

428 Supra note 146 at para. 63. However, Clements does not decide or address this question. It did not arise because the British Columbia Court of Appeal court held that the plaintiff had not satisfied the impossibility requirement. See ibid. at paras. $59,63$.

429

Resurfice, supra note 1 at para. 25. Compare this to Fairchild, supra note 89 at para. 36: "Any other outcome would be deeply offensive to instinctive notions of what justice requires and fairness demands".
} 
those cases are to be identified. Resurfice does not explain how the public, judges, and lawyers are to identify what it is about those exceptional cases that makes it fair and just in those cases, but not other cases, to treat fault, and the possibility of factual causation which is less than the probability of factual causation, as sufficient to justify the conclusion that the plaintiff has satisfied the causation requirements of the cause of action. Resurfice does not adequately identify how the public, judges and lawyers are to decide when it is just and fair to allow the imposition of liability even though, on the facts, it cannot be said, validly, that the conduct of the person to be held liable was actually a cause of the injury.

The statement in Resurfice that both examples turn on both the "impossibility of establishing causation" ${ }^{430}$ is a good enough clue to what underlies the Supreme Court's explanation of the principles of the Resurfice material contribution doctrine. It is, essentially, that there is something about the defendant's conduct that, as between the injured person and the defendant, the defendant ought to pay for injury which the defendant's negligence might have caused, unless the defendant can show, on the balance of probability, that the defendant's conduct was probably not a cause. Support for this argument exists in the Court's reasons in Bazley v. Curry, ${ }^{431}$ Hollis v. Dow Corning Corp, ${ }^{432}$ and, as mentioned, Cook v. Lewis. ${ }^{433}$

In Hollis, the majority of the Supreme Court gave a number of reasons for denying Dow the right, under the learned intermediary rule, to establish on the balance of probability that the doctor would not have passed on the proper information even if he had received it from Dow. Dow was not permitted to establish that its negligence did not make a difference. Two of the stated reasons are relevant. Plaintiffs in the circumstances of the plaintiff in Hollis should be relieved of the orthodox obligation to prove that the manufacturer's negligence

\footnotetext{
430 Resurfice, supra note 1 at para. 28 ("Once again, the impossibility of establishing causation and the element of injury-related risk created by the defendant are central").

${ }^{431}$ Bazley v. Curry, [1999] 2 S.C.R. 534, 1999 CanLII 692.

432 Supra note 121

433 Supra note 41.
} 
was, in fact, causal - that the inadequate warning instructions given to the intermediary probably made a difference - to ensure that all plaintiffs in similar circumstances will have a cause of action against either the intermediary or person ultimately responsible for the inadequate information provided to the intermediary. Denying the wrongdoer the right to show that its negligence was not a factual case is necessary to ensure that the wrongdoer's duty of care has content. ${ }^{434}$ The dissent's response in Hollis is succinct. "Liability cannot be based on failure to take measures which would have no effect and be pointless". ${ }^{435}$ The dissent stated that the "requirement that causation be established is fundamental to tort law" $^{436}$ and denied that Cook v. Lewis and Snell, which the majority had cited, allowed "treating the issue of causation as irrelevant." ${ }^{437}$ The substance of the dissent is that there was no valid reason for departing from orthodox principles that required the plaintiff to establish, on the balance of probability, that the conduct of the defendant sought to be held liable was a cause of the injury. ${ }^{438}$

About four years later, the unanimous Supreme Court wrote in Bazley v. Curry:

However, effective compensation must also be fair, in the sense that it must seem just to place liability for the wrong on the employer. Vicarious liability is arguably fair in this sense. The employer puts in the community an enterprise which carries with it certain risks. When those risks materialize and cause injury to a member of the public despite the employer's reasonable efforts, it is fair that the person or organization that creates the enterprise and hence the risk should bear the loss. This accords with the notion that it is right and just that the person who creates a risk bear the loss when the risk ripens into harm. While the fairness of this proposition is capable of standing alone, it is buttressed by the fact that the employer is often in the best position to spread the losses through mechanisms like insurance and higher prices, thus minimizing the dislocative effect of the tort within society. ${ }^{439}$

434 Ibid. at para. 61.

435 Ibid. at para. 75 per Sopinka J. and McLachlin, J., as she then was, concurring.

436 Ibid. at para. 77.

437 Ibid.

438 Ibid. especially paras. 72-77.

439 Supra note 431, [1999] 2 S.C.R. 534 at para. 31 per McLachlin, J. (as she then was) [emphasis added]. 
Resurfice clams that there is a valid reason for departing from orthodox principles in the exceptional instances to which the Resurfice material contribution doctrine applies: "basic notions of fairness and justice". ${ }^{440}$ There is at least an echo of the Bazley rationale for vicarious liability in the Resurfice rationale for the existence of the Resurfice version of material contribution doctrine.

\subsubsection{2 "Fairness and Justice" is a Third Requirement}

For the reasons set out in this section, the better conclusion is that there is an additional, separate, fairness and justice requirement. The better interpretation of Resurfice is that the plaintiff does not necessarily satisfy the requirements of Resurfice material contribution merely by satisfying the impossibility and ambit of risk requirements. Satisfying the two requirements does not entail the conclusion that it would offend basic notions of fairness and justice to dismiss the action on the grounds that factual causation was not proved on the balance of probability. There must be something more to establish that the dismissal would offend those basic notions.

\section{Resurfice states:}

In those exceptional cases where these two requirements are satisfied, liability may be imposed, even though the "but for" test is not satisfied, because it would offend basic notions of fairness and justice to deny liability by applying a "but for" approach. ${ }^{441}$

If the plaintiff satisfies the impossibility and ambit of risk requirements, does that mean that the plaintiff has established that it would offend basic notions of fairness and justice to dismiss the action on the basis that the plaintiff was not able to establish factual causation on the balance of probability? Or must the plaintiff show something more to establish that it would offend those basic notions? Is it open to the defendant to show that it would not offend those basic notions? It is not clear whether Resurfice holds: (1) the fairness and justice requirement is a third requirement which must be satisfied, in addition to the

\footnotetext{
440 Resurfice, supra note 1 at para. 25.

441 Ibid. at para. 25. Compare this to Fairchild, supra note 89 at para. 36: "Any other outcome would be deeply offensive to instinctive notions of what justice requires and fairness demands".
} 
impossibility and ambit of risk requirements, because the fairness and justice requirement is not necessarily satisfied by the plaintiff satisfying the impossibility and ambit of risk requirements; or (2) the fairness and justice requirement is satisfied by the fact of the plaintiff satisfying the impossibility and ambit of risk requirements.

Resurfice does not discuss the manner in which the "basic notions of fairness and justice" will govern the application of the Resurfice material contribution doctrine. The Supreme Court's statement that the Alberta Court of Appeal "erred in applying the material contribution test in circumstances where its use was neither necessary nor justified" ${ }^{442}$ is not relevant. First, the circumstances the Court referred to was the fact that the but-for test was applicable. Second, the statement refers to the Alberta Court of Appeal's use of the Athey material contribution test. The Supreme Court's failure to provide any guidance on the manner in which a fairness and justice requirement would control the use of Resurfice material contribution could be seen as evidence in favour of the view that this phrase was meant as merely a summary of the result of the plaintiff satisfying the impossibility and ambit of risk conditions.

The issue of whether there is a third, overriding, fairness and justice requirement, or whether fairness and justice is merely the summary of the justification for applying the Resurfice material contribution doctrine rather than orthodox causation doctrine where the impossibility and ambit of risk requirements are satisfied, exists because the text of Resurfice is ambiguous. Paragraphs 24, 25 and 26 specifically refer to "two requirements". Paragraph 24 provides, in part: "Broadly speaking, the cases in which the "material contribution" test is properly applied involve two requirements. ${ }^{443}$ Paragraph 26 is:

These two requirements are helpful in defining the situations in which an exception to the "but for" approach ought to be permitted. Without dealing exhaustively with the jurisprudence, a few examples may assist in demonstrating the twin principles just asserted. ${ }^{444}$

\footnotetext{
442 Ibid. at para. 29.

443 Ibid. at para. 24. This is the second sentence. The first is not relevant to this issue.

444 Ibid. at para. 26.
} 
However, paragraph 25 also seems to refer to a fairness and justice requirement which controls the impossibility and ambit of risk requirements: "because it would offend basic notions of fairness and justice to deny liability by applying a "but for" approach." ${ }^{445}$ The better interpretation of the concluding sentence of paragraph 25 is that it sets out a third requirement which is not necessarily satisfied merely by the plaintiff satisfying the impossibility and ambit of risk requirements. The concluding sentence is permissive. Liability may be imposed, not must imposed. If this interpretation is correct, then the applicability of Resurfice material contribution requires the additional finding that that "it would offend basic notions of fairness and justice to deny liability by applying a "but for' approach."

It can be argued that the Supreme Court meant "may" only in the sense of "assuming that the defendant has not disproved factual causation on the balance of probability and that there are no defences, other than those relating to causation - for example, a remoteness defence - available to the defendant", rather than "may" in the sense that the court must still decide if Resurfice material contribution is applicable for an additional reason. This argument should be rejected. The Court did not write "will be imposed, assuming all of the other requirements of the cause of action are satisfied, because ..." or anything equivalent. Liability cannot be imposed if a defendant has other valid, applicable, defences. The Court might have concluded there is no reason to state the obvious. But, if there are these other defences, the issue of the applicability of Resurfice material contribution issue will never arise. As the argument that "may" refers to these other defences makes "may" meaningless, it should be rejected because there is a better interpretation.

In Clements, the British Columbia Court of Appeal held that it was fair and just to dismiss the action where the plaintiff had failed to prove, on the balance of probability, that the defendant's negligence was a cause of the plaintiff's injury. ${ }^{446}$ The reason was that the plaintiff's case was nothing more than "a case like many others in which, given the current

\footnotetext{
445 Ibid. at para. 25 [emphasis added].

446 Ibid. at paras. 64-65.
} 
state of knowledge, it [was] not possible to prove whether the negligent actions of a defendant caused harm". ${ }^{447}$ The court held that plaintiff's inability to adduce the evidence required to establish factual causation on the balance of probability was not due to the type of problem described in either the first or second examples in Resurfice. ${ }^{448}$ The statement in Clements that the plaintiff's case was a case like many others suggests that the factors outside of the relationship between the injured person and the wrongdoer are relevant to the fairness and justice requirement. That factors outside of the relationship between the injured person and the wrongdoer are relevant supports the conclusion that fairness and justice is a separate, third, requirement which must be satisfied if the Resurfice material contribution doctrine is be applied to produce finding that causation has been established. ${ }^{449}$

Clements begins its summary of the meaning of Resurfice material contribution by stating that there is an "over-arching policy that the material-contribution test is available only when a denial of liability under the but-for test would offend basic notions of fairness and justice". ${ }^{450}$ The reference is to Resurfice's summary of why the material contribution doctrine is required: "In those exceptional cases where these two requirements are satisfied, liability may be imposed, even though the 'but for' test is not satisfied, because it would offend basic notions of fairness and justice to deny liability by applying a 'but for' approach." 451 However, the Court of Appeal's explanation for why the action should be dismissed does not stop at the statement that the case was "like many others in which, given the current state of knowledge, it is not possible to prove whether the negligent actions of a defendant caused harm." 452 The court added that the court did "not consider it either unfair

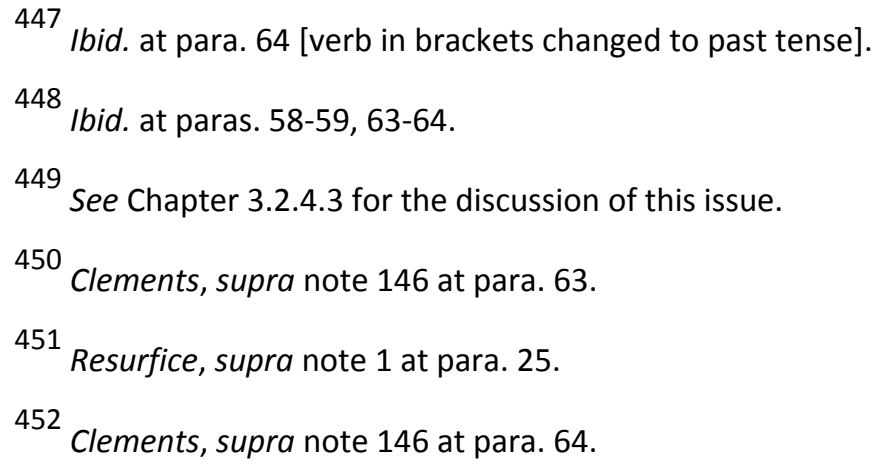


or unjust ... not to fix Mr. Clements with liability when Mrs. Clements ha[d] been unable to show factually that his negligence was a cause of her damages." 453

The Clements reasons do not entail the conclusion that the Court of Appeal would have held the Resurfice material contribution doctrine would not have been applied, on the basis of fairness and justice, even if the court had found the plaintiff had satisfied the impossibility requirement. There is nothing in the Clements reasons that suggests the court necessarily considered the better conclusion for that circumstance. The court held the plaintiff had not satisfied the impossibility requirement. The court did not refer to the fairness and justice requirement in that part of its analysis. ${ }^{454}$ The fairness and justice issue did not arise once the court held the plaintiff had not satisfied the impossibility requirement. The court's use of "over-arching policy" in its brief discussion of a fairness and justice requirement ${ }^{455}$ can be understood to have been meant only as additional explanation of, or justification for, the conclusion that, on the particular facts of Clements, the fact that the current limits of scientific knowledge was the reason why the plaintiff was not able to establish factual causation on the balance of probability, assuming this was true, did not satisfy the impossibility requirement.

Another argument supporting the conclusion that there is an overriding fairness and justice requirement is that Resurfice material contribution may result in instances where the plaintiff succeeds because the current limits of scientific knowledge are not sufficient to allow a valid conclusion on the balance of probability, but where the plaintiff would have lost if scientific knowledge was sufficient to allow a conclusion of duplicative causation. ${ }^{456}$ Assume there are two causal candidates where one is the negligence of a wrongdoer and the

\footnotetext{
453 Ibid. at para. 64.

454 See Ibid. at paras. 59, 63.

455 See ibid., paras. 63-64.

${ }^{456}$ See supra note 261.
} 
other causal candidate is some innocent factor unrelated to the wrongdoer's conduct. ${ }^{457}$ Assume both of the causal candidates, in the absence of the other, could have been the cause of the plaintiff's injury. Assume the limits of current scientific knowledge mean that, on the evidence, no qualified expert is able to provide a valid opinion that the injury was caused by one or the other of the causes, but not both. Assume, as well that no qualified expert is able to provide a valid opinion that the both causes are cumulatively necessary. Assume the wrongdoer did not do anything which, in a relevant sense, prevents the plaintiff from establishing factual causation on the balance of probability. ${ }^{458}$ The problem is the nature of the plaintiff's injury. Assume that the injury is one where factual causation requires expert evidence. Cook v. Lewis ${ }^{459}$ does not apply because there is only one wrongdoer. If the first example in Resurfice ${ }^{460}$ is read literally, Resurfice material contribution does not apply because the situation does not have two tortious causal candidates. The better view is that Resurfice material contribution does not require two or more tortious causal candidates. The

457 Innocent means the factor, if it was the conduct of a person, was never actionable.

458 These assumptions are necessary to take the facts out of the ambit of all of Athey, supra note 14, Cook $v$. Lewis, supra note 41, and McGhee and Bonnington Castings, Ltd. v. Wardlaw, both supra note 85. If both causal candidates are tortious, the sole wrongdoer will be held liable so long as those are the only two causal candidates, even if it is not possible to determine whether both were cumulatively necessary or both are individually sufficient. In either variation, the negligence is necessary. The assumption that the innocent factor is unrelated to the conduct of the wrongdoer eliminates Bonnington and McGhee as the latter was explained in Wilsher, supra note 87. In Bonnington, and McGhee as explained in Wilsher, the but-for test was used on the basis that the facts permitted a valid inference that, on the balance of probability, the negligence necessary for the injury to have occurred and was, therefore, a cause. McGhee is still, formally, authority for that use of but-for because the Wilsher explanation of McGhee was adopted in Snell, supra note 42. The Supreme Court has yet to accept the Fairchild rejection of the Wilsher interpretation. See supra text accompanying note 88 . There is some dispute as to whether the test that Bonnington used is the but-for test or some version of a material contribution test which produces a finding of factual causation on the balance of probability. The better view is that it is the but-for test. See S. H. Bailey, "Causation in negligence: what is a material contribution?" (2010) L.S. 167. It is not relevant to anything in this paper that Athey cited Bonnington as one of the authorities for the Athey version of a material contribution test: see Athey, ibid. at para. 15.

459 Supra note 41.

460

Resurfice, supra note 1 at para. 27. 
second Resurfice example is sufficient support for this conclusion. ${ }^{461}$ If Resurfice material contribution applies and its requirements are satisfied, the wrongdoer will be held liable. ${ }^{462}$

There is somewhat of an unusual twist if one considers what the result would be in the variation of example above if the evidence and state of knowledge were such that it could be held that there was duplicative causation: that both causal candidates were, in fact, causes of the injury. Under current law, the action would be dismissed on the basis of Athey. ${ }^{463}$ We can say either that the injury would have occurred even without the negligence of the wrongdoer, in the causation sense, or that the negligence of the wrongdoer did not cause any change in the injured person's original position. Thus, if Resurfice material contribution applies, the plaintiff has succeeded only because the state of the evidence and current knowledge is such that a definitive conclusion cannot be made as to which of the causal candidates was the probable cause. Perhaps this difference can be explained on the basis that, where probability cannot be validly established for either the conclusion that the negligence was or was not a cause, then it remains a possibility that it was, in law, the only cause of the injured person's change in position. As a matter of law, that possibility is eliminated where there is duplicative causation and one of the sufficient causes is an innocent factor.

\subsubsection{Factors that Might Satisfy the Fairness and Justice Requirement}

The inquiry into why it might, in a particular case, "offend basic notions of fairness and justice to deny liability" on the basis that the plaintiff failed to establish factual causation on the balance of probability could be limited to the relationship between the parties to the action. Or, the inquiry could extend to issues that affect the content of the legal system

\footnotetext{
461 Ibid. at para. 28.

462 Sienkiewicz, supra note 99, is the United Kingdom authority applying Fairchild and Barker v. Corus.

463 Athey, supra note 14 at paras. 32-33, 41.1. The basis of Rand J.'s minority concurrence in Cook v. Lewis, supra note 41 - that a wrongdoer's negligence had destroyed the plaintiff's ability to prove that negligence of another wrongdoer was a probable cause - would not help the plaintiff, even if the court was prepared to create a new exception to the but-for test.
} 
itself. These are rule of law or administration of justice issues. "Fairness", "justice", and "basic notions of fairness and justice" do not require the conclusion that the inquiry is limited to one or the other of considerations limited to, or broader than, the relationship between the injured person and the wrongdoer. The better interpretation includes both types of consideration. In the absence of any suggestion to the contrary in Resurfice, the better conclusion is that the decision whether it would offend basic notions of fairness and justice to dismiss the action merely on the basis that factual causation was not established on the balance of probability must be based on both internal and external considerations.

One of the purposes of tort law is to require a person who injures another person to make reparations for that injury. That purpose is an aspect of the concept of corrective justice that is at the core of tort law. ${ }^{464}$ "Justice" as an aspect of the rule of law includes external considerations such as the principle that like cases be treated alike. Treating like cases alike and different cases differently is the meaning of precedent. ${ }^{465}$ But that is merely an aspect of the "equality before the law" principle now enshrined in the Canadian constitutional law. Private law, as an aspect of the common law, "must be interpreted in a manner that is consistent with Charter [Canadian Charter of Rights and Freedoms] principles." ${ }^{466}$ The Quebec Court of Appeal wrote in Commission de la santé et de la sécurité du travail c. Fontaine: "justice is traditionally thought of as maintaining or restoring a balance or proportion, and its leading precept is often formulated as 'Treat like cases alike'; though we

\footnotetext{
464 Klar, Tort Law, supra note 25 at 427. "Tort litigation operates through and upon the relationship of plaintiff and defendant. Causation is the element in this relationship that functions to particularize the former as the victim of the latter's wrongdoing. The bilateral nature of tort litigation requires our asking not only 'Why can this plaintiff recover from this defendant?' but also "Why can this plaintiff recover from this defendant?'” See Ernest J. Weinrib, "Causation and Wrongdoing" (1987), 63 Chi. Kent L. Rev. 407 at 411, 412, 414 [emphasis in original].

466 See Hill v. Church of Scientology of Toronto, [1995] 2 S.C.R. 1130 at para. 91, 1995 CanLII 59; R.W.D.S.U., Local 580 v. Dolphin Delivery Ltd., [1986] 2 S.C.R. 573 at para. 25, 1986 CanLII 5 [words in brackets added]. The treat like cases alike principle is regularly quoted in criminal law cases, particularly in sentencing: see, for example, $R$. $v$. $L$. (J.E.), [1989] 2 S.C.R. 510, 1989 CanLII 32.
} 
need to add to the latter 'and treat different cases differently'." ${ }^{467}$ In Stations de la vallée de St-Sauveur inc. c. M.A, the Quebec Court of Appeal referred to

the ancient ideal, at the core of analogical judicial reasoning where coherence is understood to be a virtue, that "like cases should be treated alike". It rests upon a theory of justice ... "that insofar as ... cases are alike, they should be treated alike". It is not just the persuasiveness but also the legitimacy of judicial decision-making that is wrapped up, in part, in this ideal, itself connected to the rule of law. ${ }^{468}$

The Court of Appeal added that this principle "echoes too a legitimate concern expressed by civil law scholars ... who also argue for the importance that "les solutions demeurent cohérentes et uniformes' ," $^{469}$

A concern relevant to the scope of the Resurfice material contribution doctrine is the "floodgates" problem. This problem is connected to the principle of justice that deciding one case in a particular way requires all similar cases be treated alike. The instances to which Resurfice material contribution may apply are supposed to be exceptional. There is nothing explicit in the text of the impossibility or ambit of risk requirements that provides useful guidance on how to distinguish the exceptional cases to which Resurfice material contribution may be applied from those cases where the action is to be dismissed because the plaintiff failed to establish causation on the balance of probability. The Resurfice material contribution doctrine cannot be understood to mean that every case where negligence was established but the plaintiff failed to establish factual causation on the balance of probability - even where the defendant was able to disprove factual causation on the balance of probability - is a candidate for Resurfice material contribution. It is possible to describe most, perhaps all, cases where the plaintiff fails to establish factual causation on the balance of probability as instances where current limits of scientific knowledge are the reason the

\footnotetext{
4672005 QCCA 775 at para. 68 quoting H.L.A. Hart, The Concept of Law (Oxford: Oxford University Press, 1961) at 155.

4682010 QCCA 1509 at para. 82 [internal footnote omitted].

469 lbid. at para. 81.
} 
plaintiff could not reconstruct what happened in sufficient detail to allow the judge or jury to decide the causation issue in the plaintiff's favour. ${ }^{470}$

This concern seems to have been part of the rationale, or justification, in Clements, for the court's conclusion that it was fair and just to dismiss the action on the basis that the plaintiff had failed to establish factual causation on the balance of probability. It is explicit enough in the court's statement that the action was "a case like many others in which, given the current state of knowledge, it [was] not possible to prove whether the negligent actions of a defendant caused harm." ${ }^{471}$ According to the Court of Appeal, the plaintiff did not offer any cogent reason for treating her case different from those other cases. Clements could have paraphrased the Supreme Court's explanation for rejecting the Alberta Court of Appeal's statement as to when Athey material contribution applied by writing something similar to the following. If the plaintiff's arguments are endorsed, the only conclusion that could be drawn is that the default test for causation is the Resurfice material contribution test. This is inconsistent with the Supreme Court's judgment in Resurfice.

Is there some significance in the fact that the Supreme Court offered Cook v. Lewis as one of the two examples of fact-patterns capable of triggering the Resurfice material contribution doctrine without referring to the alternative justification in Cook v. Lewis, itself, for the reverse-onus version of the but-for test ${ }^{472}$ Rand J.'s reason for agreeing with the majority was that the negligence of each of the two negligent hunters could be said to have destroyed the plaintiff's ability to prove factual causation, under the orthodox but-for test, against the other hunter. If traditional principles had been applied, the negligence that injured the plaintiff would have also "destroyed" the plaintiff's ability to lawfully obtain the remedy provided for injury caused by that negligence. ${ }^{473}$ Perhaps the Supreme Court saw, in

\footnotetext{
470 See supra at the text between notes 348-349.

${ }^{471}$ Clements, supra note 146 at para. 64.

472 A justification which the Supreme Court had relied on in Hollis v. Dow Corning, supra note 121.

473 Cook v. Lewis, supra note 41 at 832-33. This rationale for Cook v. Lewis is discussed in some detail in Brown, Hegemony, supra note 69 at 449-55. This aspect of Cook v. Lewis forms part of the majority's rationale in Hollis,
} 
Resurfice, that this problem, in some way, is common enough in many cases of harm caused by negligence, even if it need not necessarily exist. It is unlikely that this difference is in some relevant way related to the quality or the extent of the increased risk in the particular activity. Having just criticized the Alberta Court of Appeal for asserting a version of a material contribution test which was a de facto replacement for the but-for test, the Supreme Court was likely very leery about falling into the same error.

The explicitly stated rationale for the Resurfice material contribution doctrine is fairness and justice. "In those exceptional cases where these two requirements are satisfied, liability may be imposed, even though the 'but for' test is not satisfied, because it would offend basic notions of fairness and justice to deny liability by applying a 'but for' approach." ${ }^{474}$ Resurfice does not explain why "it would offend basic notions of fairness and justice to deny liability" where the only evidence that is relevant evidence shows that it is more likely than not that the conduct of particular defendant did not cause the plaintiff's injury or, at best, the evidence is equally balanced as between caused and did not cause. The but-for doctrine and its underpinning of individual responsibility for wrongdoing is four centuries old, traditional, tort doctrine. ${ }^{475}$ Resurfice does not adequately explain what it is about the so-called "exceptional" cases that makes those factors "central"; that is, sufficient in these "exceptional" cases but not in other cases.

supra note 121, [1995] 4 S.C.R. 634 at paras. 56-57. The Court asserted that "a close analogy" could be drawn between the facts of the two cases.

474 Resurfice, supra note 1 at para. 25.

475

Vaughan Black, "The Transformation of Causation in the Supreme Court: Dilution and 'Policyization'” in T. Archibald and M. Cochrane, eds., Annual Review of Civil Litigation 2002 (Toronto: Carswell, 2003) 187 at 187; see, also, J. G. Fleming, The Law of Torts, 8th ed. (Sydney, Law Book Co., 1992) at 143, quoted by Sopinka J. and McLachlin J. (as she then was) in their dissent in Hollis at para. 74. Fleming wrote: "If such a causal relation does not exist, that puts an end to the plaintiff's case: to impose liability for loss to which the defendant's conduct has not in fact contributed would be incompatible with the principle of individual responsibility on which the law of torts has been traditionally based." (Emphasis in original.) Klar, Tort Law, states, supra note 25 at $427:$ "The theoretical importance of the issue of causal connection in a fault-based compensation process cannot be overstated. In contrast to no-fault compensation programs, negligence law must focus on the causal inquiry. For negligence law, it is the infliction of injury through the wrongdoing of another that entitles a person to full compensation, which must be provided by the wrongdoer who caused the injury." 
Clements states that there is an "over-arching policy that the material-contribution test is available only when a denial of liability under the but-for test would offend basic notions of fairness and justice" ${ }^{476}$ but does not discuss the meaning of the fairness and justice requirement beyond a cursory reference in the penultimate paragraph where the court said it was not "unfair or unjust, or just plain wrong" to dismiss the action when the plaintiff had failed to establish factual causation on the balance of probability. ${ }^{477}$ Whatever the court intended by "just plain wrong", it is probable that the original meaning of the phrase is some action contrary to the moral principles of tort law. Erik Knutsen wrote:

The material contribution test is thus the judicial loophole designed for those particularly strange and difficult cases where everyone knows that to deny the plaintiff the ability to prove the tort based on causation, in the wake of solid evidence of negligent behaviour on the part of the defendant, is just plain wrong. ${ }^{478}$

The statement in Clements that it would not be "just plain wrong" to dismiss the plaintiff's action because it was a case just like others ${ }^{479}$ also reflects fairness and justice concerns other than those as between the parties themselves. The Court of Appeal's comments should be understood to mean that the moral principles underlying tort law, that would justify the imposition of liability on the defendant if the negligence had been found to be a factual cause on the balance of probability, required the conclusion that the plaintiff should not succeed in this case because she was not able to establish that level of causal connection. ${ }^{480}$

As stated, the better interpretation of the Resurfice material contribution doctrine, as set out in Resurfice and in principle, is that the fairness and justice criterion is a separate, overriding, control which is not deemed to be satisfied by the mere fact the plaintiff satisfied

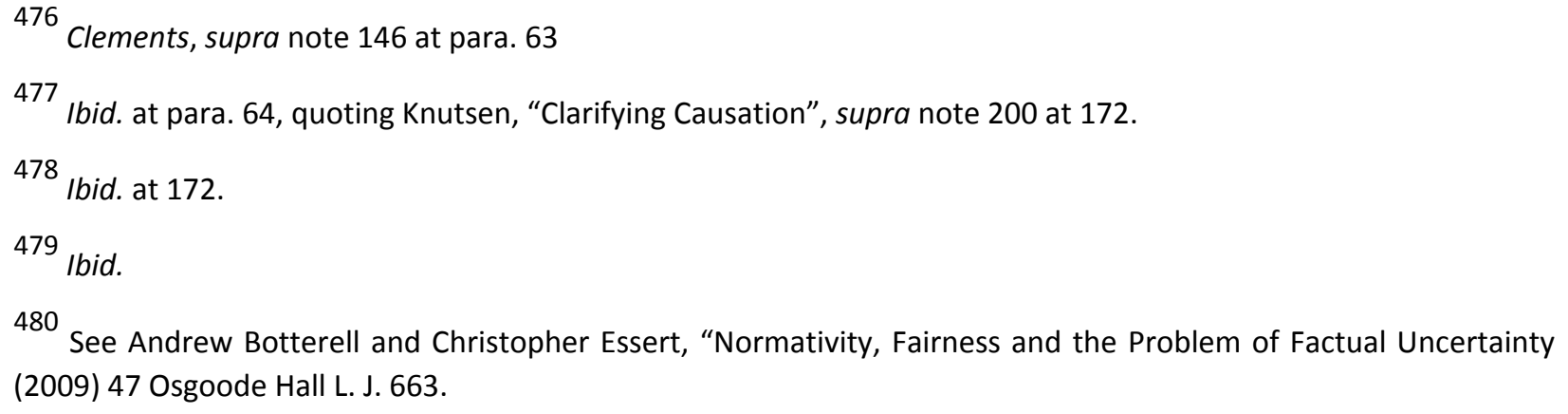


the impossibility and ambit of risk requirements. This is because fairness and justice cannot be determined by looking only at the situation as between the parties. Fairness and justice can only be determined in context, which means the courts must consider the broader concerns of the legal system and ask if and how those concerns affect the decision on the applicability of the Resurfice material contribution doctrine in a particular case. There is nothing about the circumstances of any particular type of injury, whether personal injury or property damage, or manner of injury, which, in principle, requires that the causation requirements for that form of injury necessarily be different from any other form of injury. Incidents that do not involve vehicles may be just as complicated as those which do not. ${ }^{481}$ Property damage incidents may be even more complicated. ${ }^{482}$

Nonetheless, there may be reasons unrelated to causation doctrine which warrant some types of injury, or some mechanisms of injury, having the benefit, in some circumstances, of relaxed causation requirements. Resurfice could have provided some help as to what the members of the Supreme Court intended by the phrase "basic notions of fairness and justice". It is plausible to suggest that a reason the Court did not get into that question is because it would have had to provide more detail explaining the doctrinal basis of Resurfice material contribution, including dealing with its prior contrary case law. Had the Court been prepared to spill more judicial ink on the subject of proof of causation, it could have looked to the United Kingdom decisions discussing the United Kingdom version of a causation doctrine based on fault and the possibility, not the probability, of factual causation: Fairchild $^{483}$ and Barker v. Corus. ${ }^{484}$ The Court could have considered Gregg v. Scott where the House of Lords refused to extend what United Kingdom jurisprudence calls the "Fairchild

\footnotetext{
481 I refer to the suggestion in Collins, "Causation, contribution and Clements" that vehicle dynamics is somehow different because motorized vehicles are sufficiently new that aspects of vehicle dynamics may still not be fully understood.

482 For example Bow Valley Husky (Bermuda) Ltd. v. Saint John Shipbuilding Ltd., [1997] 3 S.C.R. 1210, 1997 CanLII 307.

483 Supra note 89.

484 Supra note 99.
} 
exception" beyond cases of mesothelioma caused by asbestos exposure, so as to apply that doctrine to medical malpractice actions. ${ }^{485}$ The justification for that conclusion included the "floodgates" concern; ${ }^{486}$ that is, if the Fairchild exception were extended to medical negligence actions then there was no principled reason not to extend it to all personal injury actions so that "damages [might be] awarded in all cases in which the defendant may have caused and injury and has increased the likelihood of the injury being suffered." 487

The Supreme Court could have considered Chester v. Afshar. ${ }^{488}$ Chester is not a case where the House of Lords applied the Fairchild version of a causation test based on fault and possibility less than probability. It is a medical negligence action where the House of Lords decided that it would dispense with any requirement for a factual causation connection between the breach of duty and the injury. What is significant, for present purposes, is the justification offered for that conclusion. In Chester, the question the House of Lords decided was: "[I] is this a case where courts are entitled to see to it that justice is done despite the absence of [legal] causal connection ?" $^{489}$ The House of Lords held that, in an action against a physician based on lack of informed consent, the duty of care a physician owes to the patient to explain adequately the risks of the recommended procedure is so important that the cause of action for breach of the duty must be actionable without factual causation in order to provide meaningful content and a remedy for a breach of the duty. ${ }^{490}$

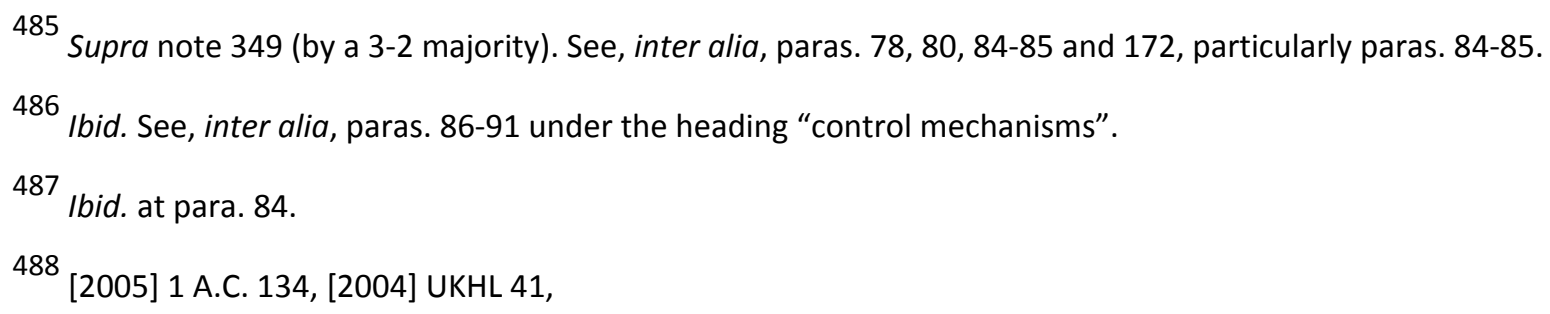
majority. All of members of the panel wrote separate reasons. Lord Hope's statement of the question is correct for all of the speeches. I added "legal" because there was a causal connection in Chester in this sense. Had the operation not occurred on the day it occurred, then the disability that the plaintiff developed because of the operation would not have occurred because of that operation. Similarly, had the operation never occurred, the disability would never have occurred because of the operation.

490

Ibid., [2004] UKHL 41, particularly paras. 16-18, 24, 54-60, 85-88, 92-93, 101. 
To leave the patient who would find the decision difficult without a remedy, as the normal approach to causation would indicate, would render the duty useless in the cases where it may be needed most. This would discriminate against those who cannot honestly say that they would have declined the operation once and for all if they had been warned. I would find that result unacceptable. The function of the law is to enable rights to be vindicated and to provide remedies when duties have been breached. Unless this is done the duty is a hollow one, stripped of all practical force and devoid of all content. It will have lost its ability to protect the patient and thus to fulfil the only purpose which brought it into existence. On policy grounds therefore I would hold that the test of causation is satisfied in this case. ${ }^{491}$

Thus, the physician will be liable for injury that results from a properly performed procedure if the physician breached the duty to advise, even if the plaintiff is not able to establish, on the balance of probability, that the plaintiff would not have had the procedure if properly advised. One of the judges in the 3-2 Chester majority wrote: "[t]his result is in accord with one of the most basic aspirations of the law, namely to right wrongs. Moreover, the decision announced by the House today reflects the reasonable expectations of the public in contemporary society." 492 The statement is a more elegant version of the "everyone knows" statement in Knutsen, "Clarifying Causation". 493

There might be something about the nature of the injury, itself. Sienkiewicz v. Greif begins: "Mesothelioma is a hideous disease that is inevitably fatal." 494 The same point could once have been made about HIV and AIDS. Neither fatality nor severity is inherent in many other modes of incident causing personal injury. Personal injury might be considered to be sufficiently more important than property damage that plaintiffs alleging personal injury are allowed leeway in proof of causation that plaintiffs alleging property damage are not.

It is essential "to preserve the general perception of the law as system of rules which is fair between one citizen and another." ${ }^{495}$ This perception cannot be preserved if the mere fact

491 Ibid. at, for example, para. 88. See also, paras. 23-25, 56-57, 61, 92, 101.

492 Ibid. at para. 25.

493 Supra note 200 at 172 . The text passage containing the phrase is quoted at the text accompanying note 478. 494 Sienkiewicz, supra note 99 at para. 1.

495 See White v. Chief Constable of South Yorkshire Police, [1999] 2 A.C. 455 at 511, [1998] UKHL 45 at para. 48. 
that the plaintiff satisfies the Resurfice material contribution impossibility and ambit requirements is sufficient of itself to make that test applicable. If the mere fact that the plaintiff satisfies the Resurfice material contribution impossibility and ambit of risk requirements is not sufficient, of itself, to make that test applicable, this perception cannot be preserved without some principled basis for choosing between those cases which will be held to satisfy the requirements of the test and those which do not. Preserving this general perception of fairness requires that the rules by which the choice is made at least seem to not be arbitrary. The rules must provide some principled basis for explaining the after-thefact decision to impose or not impose liability. The rules must provide some principled basis for citizens to determine whether they will act or not act in a way that could expose them to liability.

The only method of choosing indicated by the text of Resurfice is the "basic notions of fairness and justice" requirement. The reason for allowing the imposition of liability (assuming all other requirements of the cause of action are satisfied) is that it would offend "basic notions of fairness and justice to deny liability by applying a 'but for' approach". 496 Resurfice states that the but-for test "recognizes that compensation for negligent conduct should only be made where a substantial connection between the injury and the defendant's conduct is present." 497 Given that view of the meaning of but-for, it necessarily follows that there has to something exceptional about the incident which resulted in the plaintiff's injury so that the plaintiff is to be allowed to succeed against the defendant even though the plaintiff has not been able to show a "substantial connection" between the defendant's negligence and the plaintiff's injury.

There are analogies to a fairness and justice control on the scope of Resurfice material contribution in the jurisprudence establishing the limit of responsibility in instances where causation has to be proven on the balance of probability. One example is the limiting

\footnotetext{
496 Resurfice, supra note 1 at para. 25.

497 Ibid. at para. 23.
} 
principle called remoteness or proximate cause. It seems a valid analogy that if fault and factual causation are not enough where factual causation must be established on the balance of probability because something more is required (whether called foreseeability, or lack of remoteness, or whatever other label is applied to describe the reason why the factual cause may be used as a basis for imposing liability), ${ }^{498}$ then fault and the mere possibility of factual causation should not be enough, either, under Resurfice material contribution. Something more should be required there, too. The situation is also analogous to the extent of responsibility analysis undertaken at the last stage of the duty of care analysis, where the courts consider whether there is some overriding policy reason to deny a conclusion arrived at under the first stage that there is a prima facie duty of care. ${ }^{499}$ Support for this contention exists by analogy to Childs v. Desormeaux ${ }^{500}$ where the Supreme Court remarked that "[t]he law of negligence not only considers the plaintiff's loss, but explains why it is just and fair to impose the cost of that loss on the particular defendant before the court." ${ }^{501}$

Circumstances that could militate against the imposition of liability as a result of the use of Resurfice material contribution might include the amount of the liability which will be imposed on a deep-pocket defendant whose blameworthiness is considered minor where there is another far more blameworthy defendant with significantly insufficient assets. Or, there might be a valid reason why the more blameworthy wrongdoer cannot successfully be sued either by the plaintiff (for damages) or a defendant (for contribution) so that the wrongdoer whose blameworthiness, in the moral sense, is minor is exposed to paying all or most of the plaintiff's compensable damages. This concern should be significant if the liability of a defendant held liable, through the use of the Resurfice material contribution

\footnotetext{
498 See generally Klar, Tort Law, supra note 25 at 467; generally Klar, Tort Law, c. 12. See also, inter alia, Mustapha v. Culligan of Canada Ltd., [2008] 2 S.C.R. 114 at para. 12, 2008 SCC 27: "The remoteness inquiry asks whether 'the harm [is] too unrelated to the wrongful conduct to hold the defendant fairly liable'", quoting Allen M. Linden and Bruce Feldthusen, Canadian Tort Law, 8th ed. (Toronto: LexisNexis, 2006) at 360.

499 See Odhavji Estate, supra note 405 and Cooper v. Hobart, [2001] 3 S.C.R. 537, 2001 SCC 79. See generally Klar, Tort Law, supra note 25 at 167-76.

500 [2006] 1 S.C.R. 643, 2006 SCC 18.

501 Ibid. at para. 25 referring to the "proximity" requirement of the duty of care [emphasis added].
} 
doctrine, is solidary (joint) so that the defendant will bear all or most of the burden of satisfying the plaintiff's judgment. This concern could be alleviated, in some instances, if the liability of the defendant in such circumstances is proportional (several) only. ${ }^{502}$ It is, after all, intrinsic to the material contribution to risk fact pattern that there is also a possibility that a defendant's negligence was not, in fact, a cause. There is, after all, even the possibility that a defendant's negligence did not actually increase the risk of the occurrence of the injury that occurred. Decisions in negligence as to what happened in the based are not based on certainties, even though they are treated as expressing a certainty once made. ${ }^{503}$

\subsubsection{Procedural issues}

If there is an overriding "fairness and justice requirement", who decides that issue where the case is tried with a jury? It must be the judge, not the jury. "Basic notions of fairness and justice" has to be an issue of law, even if there are some issues of fact a jury would decide in order for the judge to make the decision. Who has the burden of proof and what is the standard? The standard of proof question must be the balance of probability. ${ }^{504}$ The burden of proof on the fairness and justice requirement is probably the plaintiff's, although that is not as certain. If the ultimate applicability of Resurfice material contribution depends on the court deciding whether there is something more about that particular case that justifies, or does not justify, the application of that doctrine, then the answer to where the burden of proof lies may depend on how the question is framed. Is the question whether the doctrine

\footnotetext{
502 This was the United Kingdom approach under the Fairchild version of material contribution, see Barker $v$. Corus, supra note 99 and Klar, supra note 25 at 445-46, n. 85. Within weeks of Barker v. Corus, the United Kingdom Parliament restored joint and several liability for mesothelioma cases: see the Compensation Act 2006 (U.K.), 2006, c. 29 and Sienkiewicz v. Grief, supra note 99 at para. 1. Sienkiewicz, ibid., sets out the current form of the Fairchild version: "when a victim contracts mesothelioma each person who has, in breach of duty, been responsible for exposing the victim to a significant quantity of asbestos dust and thus creating a 'material increase in risk' of the victim contracting the disease will be held to be jointly and severally liable for causing the disease."

503

Athey, supra note 14 at para. 28.

504

See McDougall, supra note 154. "Almost certainly" because one can never say never about any aspect of the common law that is judge made. See National Westminster Bank PIc v. Spectrum Plus Limited \& Ors, [2005] 2 A.C. 680, [2005] UKHL 41 at para. 41: "Never say never' is a wise judicial precept, in the interest of all citizens of the country." Also, any law made by judges is subject to revision by a legislature acting constitutionally.
} 
ought to be applied? Or is the question whether the doctrine ought not to be applied? The former phrasing suggests the onus should be on the plaintiff; the latter on the defendant.

The Supreme Court has held that it will "alter the incidence of the ultimate burden of proof when the underlying rationale for its allocation is absent in a particular case" $\mathrm{s}^{505}$ and that "[a]though the legal burden generally rests with the plaintiff, it is not immutable. ... Valid policy reasons will be sufficient to reverse the ordinary incidence of proof." 506 If there are valid policy reasons to create a rule under which a plaintiff is able to establish the causation requirements of a cause of action without proving factual causation on the balance of probability then, in principle, there could be valid reasons supporting the argument that the defendant should have the burden of satisfying the court that the doctrine should not apply where the plaintiff has satisfied the impossibility and ambit of risk requirements. The Court could have said in Resurfice that if the plaintiff satisfies the impossibility and ambit of risk requirements, the material contribution doctrine applies unless the defendant establishes that it would offend fairness and justice to permit the plaintiff to succeed notwithstanding that the plaintiff had not established factual causation on the balance of probability. It did not. The fairness and justice requirement seems to be an intrinsic part of the Resurfice material contribution doctrine, not a defence that might prevent the application of the doctrine. In the absence of any direction from the Supreme Court, the general rule must apply. The plaintiff has the burden of proof on all of the components of the plaintiff's cause of action.

\footnotetext{
505 Snell, supra note 42 at 321. See also Rainbow Industrial Caterers Ltd. v. Canadian National Railway Co., [1991] 3 S.C.R. 3 at 15-16, 1991 CanLII 27. National Trust Co. v. Wong Aviation Ltd., [1969] S.C.R. 481.
} 


\subsubsection{Conclusion}

Botterell and Essert, "Factual Uncertainty", ${ }^{507}$ is an attempt to provide an explanation for Resurfice's reference to "basis notions of fairness and justice" in the "underlying normative principles on which tort law is based". The authors state:

... [O]ne of our goals is to offer an account of what the Supreme Court of Canada might have meant by its reference to "basic notions of fairness and justice." We will argue that to resolve various problem cases, attention should be paid not to the nature and structure of the concept of causation, but rather to the underlying normative principles on which tort law is based. We will focus on what are sometimes called "reciprocal norms of conduct." These reciprocal norms of conduct impose obligations on individuals to maintain fair terms of interaction with one another. Our claim is that tort law's commitment to maintaining fair terms of interaction between individuals, a commitment that typically requires a plaintiff to establish causation using the but-for test, sometimes allows, in atypical cases, for the imposition of liability absent but-for causation. ${ }^{508}$

While there are cases in which "tort law's commitment to maintaining fair terms of interaction between individuals ... typically requires a plaintiff to establish causation" on the balance of probability, that commitment could also support the use of standard of proof less than the balance of probability in exceptional cases. ${ }^{509}$ Claims based on mesothelioma due to alleged wrongful exposure, such as those in Fairchild, should they occur in Canada in circumstances that permit a cause of action to exist, ${ }^{510}$ could be seen as an example of the type of case justifying the use of a causal connection which is not established on the balance of probability, as a matter of fairness and justice between the parties. However, the facts of Clements do not. To the extent that difference in result is seen to be consistent with the moral basis of tort law, it is principled.

In 1997, McLachlin, J., (as she then was) wrote, extra-judicially, that the "all or nothing" aspects of the but-for test are sometimes problematic.

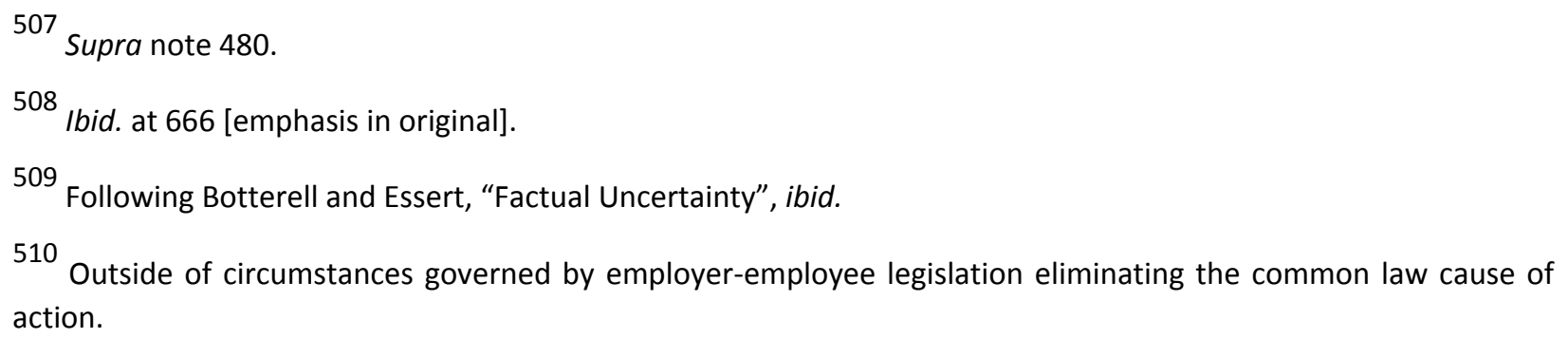


In recent years, a conflation of factors have caused lawyers, scholars and courts to question anew whether the way tort law has traditionally defined the necessary relationship between tortious acts and injuries is the right way to define it, or at least the only way. This questioning has happened in the United States and in England and has surfaced in Australia. And it is happening in Canada. Why is this happening? Why are courts now asking questions that for decades, indeed centuries, did not pose themselves, or if they did, were of no great urgency? I would suggest that it is because too often the traditional 'but-for', all-or-nothing, test denies recovery where our instinctive sense of justice - of what is the right result for the situation - tells us the victim should obtain some compensation. ${ }^{511}$

This passage, too, can be seen as evidence supporting the view that the "basic notions of fairness and justice" dictum is intended to be an overriding control. The Resurfice material contribution doctrine should not be used unless "our instinctive sense of justice - of what is the right result for the situation - tells us the victim should obtain some compensation" 512 because "[a]ny other outcome would be deeply offensive to instinctive notions of what justice requires and fairness demands". ${ }^{513}$ Otherwise, applying the doctrine would be "just plain wrong". 514

Russell Brown has written that "in equating risk with harm, [Resurfice] ... transformed causation from an instance of corrective justice to a distributive ... device." ${ }^{515}$ That is another reason why the better interpretation of Resurfice material contribution doctrine is that it is subject to an overriding fairness and justice requirement.

\footnotetext{
511 McLachlin, "Proving the Connection", supra note 18 at 16 [emphasis in original].

512 Resurfice, supra note 1 at para. 25.

513 Fairchild, supra note 86 at para. 36.

514 A fair, as between the parties, analysis of the evidence in Clements should lead to conclusion that Ms. Clements' case was not strong enough to meet this threshold. It certainly was not if one accepts the conclusion that the evidence meant the accident probably would still have happened, as it did, even if the defendant had not been negligent. However, even if one does not accept this view, it seems wrong to claim that her victory was the only outcome permitted by fairness and justice.
}

515 Brown, "Hegemony", supra note 69 at 449. 


\subsection{5 "Material" Increase in Risk - How Much Possibility is Enough Possibility?}

The label Resurfice uses for the alternative method of establishing causation is a "material contribution. ${ }^{516}$ What Resurfice means by "material contribution" is conduct which, in the circumstances, was possibly a cause of the injury and, therefore, produced a relevant for law increase in the risk of the occurrence of the injury that occurred. It does not mean negligence which was found to have been a probable cause of the occurrence of the injury. ${ }^{517}$ If "material increase" means anything in this doctrine, it means "legally significant". This is not a statement about factual causation. It is a statement about the requirements for legal responsibility: that some aspect of the increase in the risk is sufficient to allow the increase to be described as unreasonable in law, so that the conduct which is possibly a cause of the increase may be labelled negligent, assuming all of the other criteria for a duty of care and breach of the duty of care are satisfied. "Could possibly be a cause" is the meaning of "contribution" to cause. Something either is, or is not, possibly a cause. "Material", then, is "immaterial" to causation. ${ }^{518}$ It is a "vacuous, or at best impressionistic, incantation". 519 "Material" in the Resurfice material contribution doctrine is as meaningless as "material" is in the Athey material contribution doctrine.

The Resurfice material contribution permits a finding of causation based on possibility less than probability. If a "material" increase in risk is to be understood to mean anything that is more than a trivial increase (as some cases have already hinted ${ }^{520}$ ), then how much of a possibility of factual causation is more than trivial? A $1 \%$ possibility is not trivial if it

\footnotetext{
516 Resurfice, supra note 1 at para. 24.

517 See Chapter 3.1.

518 Gillian Demeyere's description of the significance of the Athey material contribution test in Gillian Demeyere, “The Material Contribution Test: An Immaterial Contribution to Tort Law" (2000) 34 U.B.C. L. Rev. 317.

519 Jane Stapleton's description of the content of the American "substantial factor" test in Jane Stapleton, "Causein-Fact and the Scope of Liability for Consequences" (2003) 119 L.Q.R. 388 at 439.

520 See Farrant v. Latkin and Nattrass v. Weber, both supra note 144. This is implicit in M.B v. 2014052 Ontario Ltd., supra note 141.
} 
corresponds to a large amount of money. The prospect that even a $1 \%$ possibility will correspond to a large sum is quite likely in many class actions. In any event, how can any amount of possibility be considered trivial, expect on arbitrary policy reasons, in a doctrine where causation is based on the existence of possibility?

\subsubsection{Miscellaneous Issues}

The justification for the existence of the Resurfice material contribution doctrine is the justification that the Supreme Court used for vicarious liability in Bazley v. Curry: the creation of a risk of injury in circumstances for which there ought to be compensation for the injury when that risk manifests in injury. ${ }^{521}$ In principle, there seems to be no reason why the Resurfice material contribution should not be available where the basis upon which a defendant will be held liable is vicarious liability only.

The tort in Resurfice was negligence. There is nothing in Resurfice material contribution doctrine, nor anything in the text of Resurfice, that requires the doctrine be limited to torts based on negligence. ${ }^{522}$ There is nothing in the text of Resurfice that suggests that the Supreme Court intended to limit the doctrine to instances of negligence. The arguments for less restrictive requirements for factual causation might be stronger in the case of intentional torts.

\footnotetext{
${ }^{521}$ Supra note 431. See generally David Cheifetz, "Materially Increasing The Risk Of Injury As Factual Cause Of Injury: Fairchild v. Glenhaven Funeral Services Ltd. In Canada" (2004) 29 Adv. Q. 1 at 273-75.

522 The tort of the perpetrator (W) in B.(M.) v. 2014052, supra note 141, was assault. It appears the corporation was held liable vicariously. It appears the version of material contribution applied by the trial judge, in deciding what questions could be put to the jury, was Athey material contribution. The Ontario Court of Appeal held the trial judge should have used the but-for test; nonetheless, on the evidence, the result of the trial judge's ruling on the questions was correct. The Court of Appeal's reasons do not discuss any difference between Resurfice material contribution and Athey material contribution. One reason might be that the author of the $B$.(M.) reasons was the author of the majority reasons in Barker v. Montfort Hospital, supra note 112, so the premise in B.(M.) was that Resurfice material contribution is Athey material contribution with more restrictive preconditions. On that issue, see supra at the text accompanying notes 112-117.
} 
In B.(M.) v. 2014052, ${ }^{523}$ the Ontario Court of Appeal asserted that "[t]he material contribution test assumes the existence of other potentially contributing causes, but due to the impossibility of isolating each cause, the tortfeasor is held liable for the whole of the injury", not a lower proportion. ${ }^{524}$ This is a correct statement if Resurfice material contribution doctrine is merely a revised version of Athey material contribution doctrine, as the Ontario Court of Appeal seems to have held in Barker v. Montfort Hospital. ${ }^{525}$ It need not be, otherwise. There is nothing in the reasons that suggests the panel in B.(M.) considered Barker v. Corus. ${ }^{526}$ The issue of the extent of liability under Resurfice material contribution did not arise because the Court of Appeal held the but-for test applied. ${ }^{527}$ This issue has not been discussed in any reported Canadian decision. Whether liability under Resurfice material contribution is solidary or proportional - joint and several or merely several - is one of the issues that may be answered by the Supreme Court in its Clements decision. The awards in all trial decisions that purported to apply Resurfice material contribution have been for the amount of the assessed, compensable, damages (less contributory fault if any). The awards have not been for just the amount of the defendant's proportional (several) share (the percentage produced by multiplying the compensable amount by the percentage by which the defendant increased the risk), as would be the case under United Kingdom version of the Fairchild version of the material contribution doctrine. ${ }^{528}$

Assume a situation where only one person's conduct is the cause of the injury, but there is separate, unrelated, tortious and innocent conduct. This pattern could be an instance of duplicative causation. Or, it could be an instance of the problem of insufficient evidence to

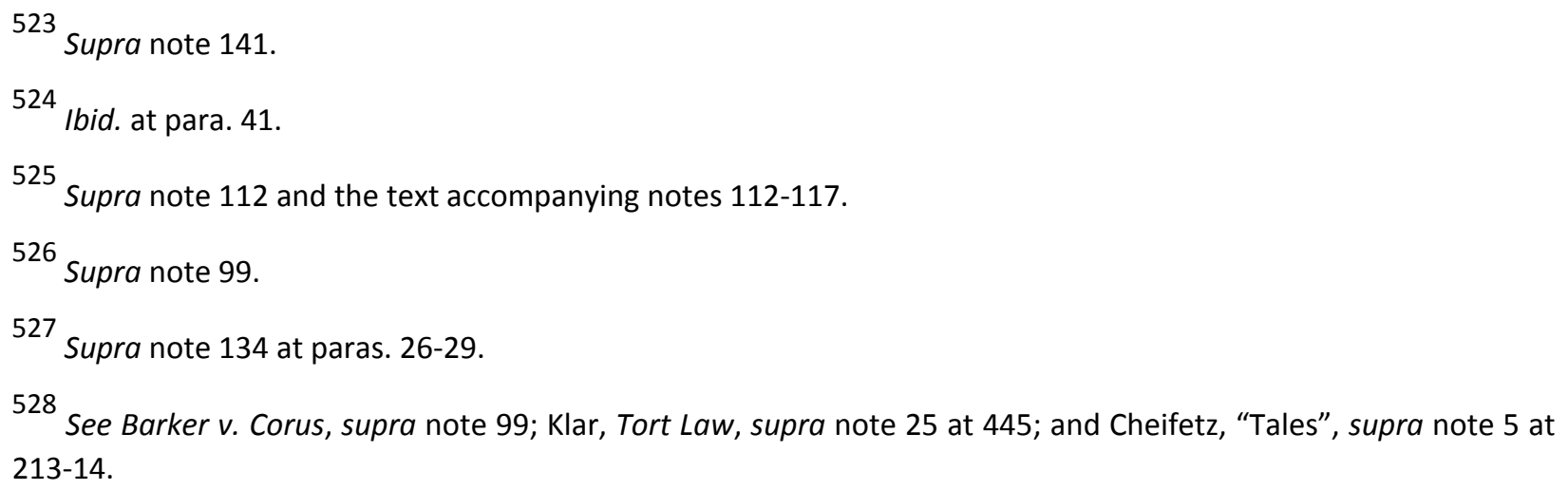


prove, on the balance of probability, whether tortious conduct is a factual cause. The evidence might show that: (1) on the balance of probability, both aspects of defendant's conduct were cumulatively necessary for occurrence of the injury; or, (2) on the balance of probability, only one or the other of the aspects is the cause; or, (3) the evidence might show that, on the balance of probability, each of the tortious and innocent conduct was separately sufficient. None of the choices create a doctrinal problem for current tort law. In the first situation the negligent conduct is an actionable cause. ${ }^{529}$ In the second situation, the negligent conduct is a cause if that is what the evidence shows. Otherwise it is not. In the third variation, if there is duplicative causation, then the negligent conduct, although also a factual cause, is not actionable under current law. ${ }^{530}$

The consequences of Resurfice material contribution on proof of factual causation in mass tort actions or class actions (at the certification state or the common issues trial) are unclear. Both examples in Resurfice describe problems of proof of causation in single incidents where the problem is proof, on the balance of probability, that the negligence of one person or an identifiable number of persons was a factual cause of the injury. However, in principle there is nothing about the Resurfice material contribution doctrine that necessarily precludes its use in mass tort actions or class actions. ${ }^{531}$

\footnotetext{
529 Athey, supra note 14 at para. 41.2. This was also the Wilsher, supra note 87, explanation of McGhee until that explanation was overruled by the House of Lords in Fairchild, supra note 89.

530

Athey, supra note 14 at para. 41.1.

531

On this issue see Collins, "Causation, contribution and Clements", supra note 191; Lynda M. Collins and Heather McLeod-Kilmurray, "Material Contribution to Justice? Toxic Causation after Resurfice Corp v. Hanke (2010) 48 Osgoode Hall L.J. 411; and, Craig Jones, "Reasoning Through Probabilistic Causation in Individual and Aggregate Claims: The Struggle Continues" (2011) 39 Adv. Q. 18.
} 


\section{Conclusion}

It has been said that "the general rule [is] that insuperable evidential problems are the claimant's hard luck." ${ }^{532}$ The Resurfice material contribution doctrine does not abolish that general rule. If the availability of Resurfice material contribution is as limited as the practice over the past five years suggests it is, that practice is affirmation of the general rule. In the English text of Resurfice, the Supreme Court introduced the discussion of causation principles by declaring: "Much judicial and academic ink has been spilled over the proper test for causation in cases of negligence. It is neither necessary nor helpful to catalogue the various debates. It suffices at this juncture to simply assert the general principles that emerge from the cases." ${ }^{533}$ In the French text, that paragraph is: "La question du critère à appliquer pour analyser le lien de causalité en matière de négligence a été traitée en profondeur dans la jurisprudence et dans la doctrine. II n'est ni nécessaire ni utile de décrire les divers débats. II suffit à ce stade d'énoncer simplement les principes généraux qui se dégagent de la jurisprudence." 534 Whatever the Supreme Court might have intended, the Resurfice reasons barely begin the process of clarifying the jurisprudence. If the Resurfice reasons moved the jurisprudence even one small step forward out of the shallower portions of the mire, they concurrently pushed it at least two larger strides back into deeper quagmire. $^{535}$

Cheifetz, "Snell Inference" was published in 2005. Part of its conclusion about the state of Canadian jurisprudence on the meaning of factual causation in tort was that "clarity, predictability and ease of use are not defining characteristics". ${ }^{536}$ One can now predict that

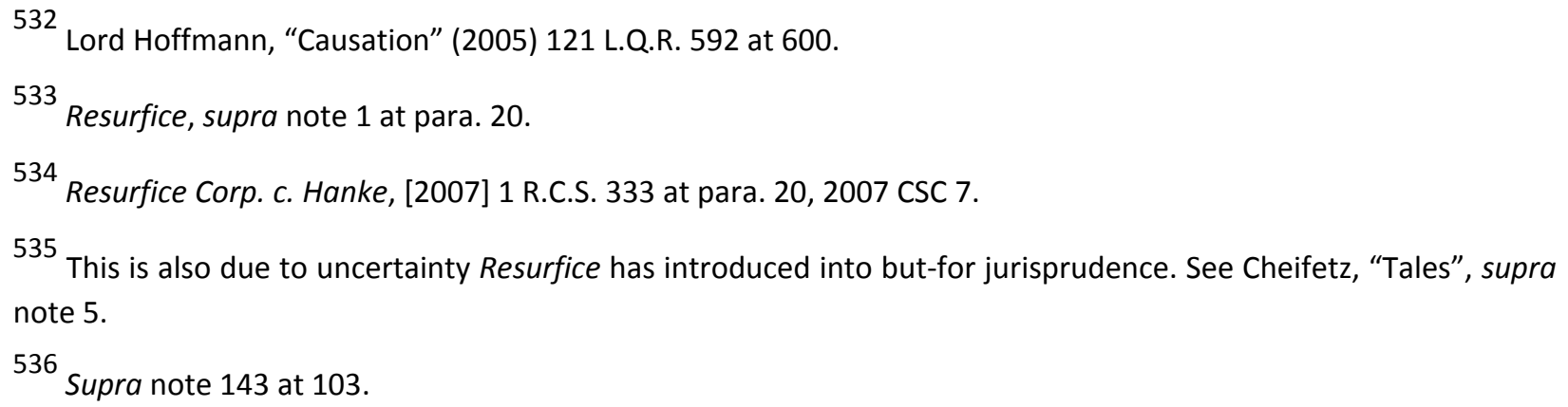


the but-for test will be used in most actions in tort based on negligence; otherwise, the conclusion remains correct. Whatever Resurfice means has had no appreciable effect on the results of the cases, other than to sometimes change judges' and lawyers' language. ${ }^{537}$ It is undeniable that judges are now formally applying the but-for test, not the Athey material contribution test, to find the plaintiff has established factual causation in cases where, before Resurfice, the judges would have used Athey material contribution. ${ }^{538}$ However, there has been only one reported case where a judge admitted this. ${ }^{539}$ There are no cases, since Resurfice, holding that a plaintiff would have been able to establish factual causation under Athey material contribution but is not able to under but-for and cannot use Resurfice material contribution to establish causation, therefore must now fail. ${ }^{540}$ However, no case in which a trial judge applied Resurfice material contribution as the basis for finding the plaintiff had established causation has yet survived appeal. ${ }^{541}$ In terms of actual results, of plaintiffs or defendants winning, it is as if Resurfice never happened.

537 Klar, Tort Law, supra note 25 at 450, n. 113, describes the current status of Resurfice material contribution as a "talking point" for lawyers and judges.

538 Even in British Columbia where the British Columbia Court of Appeal has held that but-for means what Athey's "materially contributed" meant. See supra note 144 and accompanying text.

539

Frazer v. Haukioja, supra note 35, 2008 CanLII 42207 at para. 214. There are cases where it would defy reality to suggest the trial judge would not have used Athey material contribution before Resurfice; for example, Goodman v. Viljoen, 2011 ONSC 821.

540 In the only post-Resurfice cases that I know of in which appellate courts held that the trial judge had erred in using Athey material contribution to find fact causation, the appellate courts held that factual causation was not established under either but-for or (seemingly) Athey material contribution without commenting on the status of Athey material contribution (Fullowka, supra note 146); the trial judge's findings of fact satisfied the but-for test (Moore v. Wienecke, supra note 146); or did not satisfy the but-for test and sent the action back for a new trial for that reason, and other errors of law, without commenting on whether the use of Athey would have been valid before Resurfice (Donley Investments Limited v. Canril Corporation, supra note 146).

${ }^{541}$ This is one of the issues in Clements, supra note 146. 